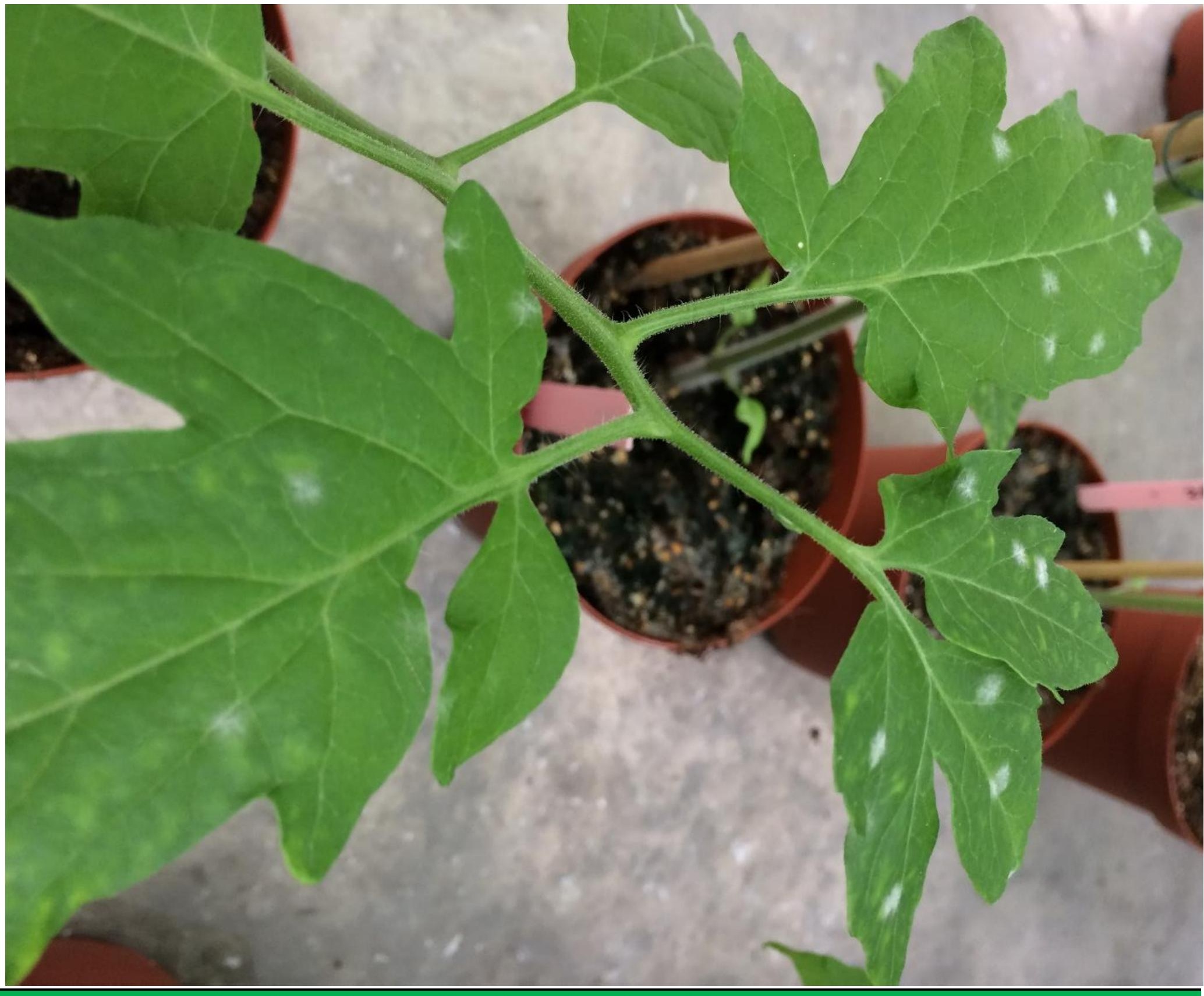

Fysisch-chemische inductie van plantweerbaarheid

L.H. Stevens, S.J. Breeuwsma, Y Griekspoor, B Rutgers

Stichting

Programmafonds

Glastuinbouw

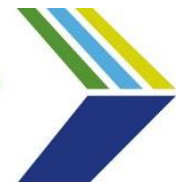

Florensis

(S)ignify PHILIPS

\section{syngénta}

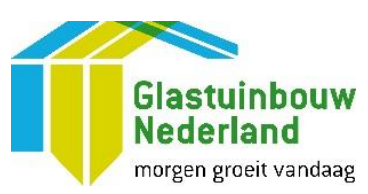

morgen groeit vandaag
Productschap $/$ Tuinbouw 


\title{
Fysisch-chemische inductie van plantweerbaarheid
}

\author{
L.H. Stevens, S.J. Breeuwsma, Y Griekspoor, B Rutgers
}

Wageningen University \& Research

Dit onderzoek is uitgevoerd binnen de PPS Fysisch-chemische inductie van plantweerbaarheid (KV 1509-084) door de Stichting Wageningen Research (WR), business unit Biointeracties en Plantgezondheid, Wageningen Plant Research, voor de Topsector Tuinbouw \& Uitgangsmaterialen (T\&U) in het kader van innovatiethema/koepel PPS 'Het nieuwe doen in plantgezondheid'.

WR is een onderdeel van Wageningen University \& Research, samenwerkingsverband tussen Wageningen University en de Stichting Wageningen Research

Wageningen, februari 2020

Glastuinbouw Nederland 
L.H. Stevens, S.J. Breeuwsma, Y Griekspoor, B Rutgers, 2020. Fysisch-chemische inductie van plantweerbaarheid. Wageningen Research. 68 blz.; 63 Figuur; 2 tab.; 36 ref.

Dit rapport is gratis te downloaden op https://doi.org/10.18174/524870.

Samenvatting. In dit rapport wordt verslag gedaan van onderzoek naar de interactie tussen rood/verrood-LED-stuurlicht en inductie van plantweerbaarheid middels elicitors. Het onderzoek bestond uit een reeks min of meer uniforme kasexperimenten uitgevoerd met groepen van jonge tomatenplanten als modelgewas, aangevuld met gerbera en enkele perkplanten als sierteeltgewassen. Het beoogde weerbaarheidseffect betrof het zogenoemde systemic acquired resistance (SAR). De effecten van de behandelingen werden vastgesteld door bepaling van salicylzuur, van expressie van pathogenesis related (PR) proteins, en van de meeldauwontwikkeling.

Trefwoorden: Systemic acquired resistance, plantweerbaarheid, stuurlicht, tomaat, gerbera, viola, petunia, Oidium neolycopersici, echte meeldauw, salicylzuur, pathogenesis related protein

(C) 2020 Wageningen, Stichting Wageningen Research, Wageningen Plant Research Biointeracties en Plantgezondheid, Postbus 16, 6700 AA Wageningen; T 03174807 00; www.wur.nl/plant-research

KvK: 09098104 te Arnhem

VAT NL no. 8113.83.696.B07

Stichting Wageningen Research. Alle rechten voorbehouden. Niets uit deze uitgave mag worden verveelvoudigd, opgeslagen in een geautomatiseerd gegevensbestand, of openbaar gemaakt, in enige vorm of op enige wijze, hetzij elektronisch, mechanisch, door fotokopieën, opnamen of enige andere manier zonder voorafgaande schriftelijke toestemming van Stichting Wageningen Research.

Stichting Wageningen Research is niet aansprakelijk voor eventuele schadelijke gevolgen die kunnen ontstaan bij gebruik van gegevens uit deze uitgave.

Foto omslag: Echte meeldauw (Oïdium lycopersicum) op tomaat 


\section{Inhoud}

$\begin{array}{ll}\text { Woord vooraf } & 7\end{array}$

$\begin{array}{ll}\text { Samenvatting } & 8\end{array}$

1

$\begin{array}{ll}\text { Inleiding; doelstelling } & 9\end{array}$

2

Achtergrond; induceerbare plantweerbaarheid, elicitors en licht

4.1 Vergelijking van elicitors onder rood en verrood stuurlicht 19

4.1.1 Inleiding 19

4.1.2 Uitvoering van het experiment $\quad 20$

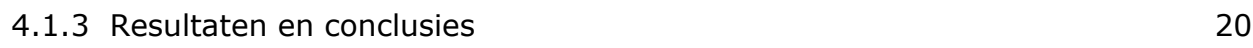

4.2 Periode en duur van de LED-behandelingen per etmaal; salicylzuur en jasmonzuur

4.2.1 Inleiding $\quad 24$

4.2.2 Uitvoering van het experiment $\quad 25$

4.2.3 Resultaten en conclusies $\quad 26$

4.3 Stuurlicht voor en na meeldauwinoculatie; invloed van PAR op SAR 31

4.3.1 Inleiding 31

4.3.2 Uitvoering van het experiment 33

4.3.3 Resultaten en conclusies $\quad 36$

$\begin{array}{lll}4.4 & \text { Effect van stuurlicht voor en na priming } & 41\end{array}$

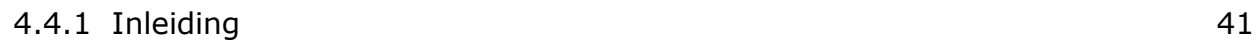

4.4.2 Uitvoering van het experiment $\quad 42$

4.4.3 Resultaten en conclusies $\quad 43$

4.5 Inductie van SAR bij enkele siergewassen onder stuurlicht 50

4.5.1 Inleiding $\quad 50$

4.5.2 Uitvoering van het experiment 51

4.5.3 Resultaten en conclusies $\quad 51$

4.6 Een eventuele rol van blauw licht 53

4.6.1 Inleiding 53

4.6.2 Uitvoering van het experiment 54

4.6.3 Resultaten en conclusies $\quad 55$

6.1 Bladmonstername en monstervoorbewerking 63

6.2 Glucanase-assay 63

6.3 Bepaling van PR1-expressie in tomaat 63

6.4 Bepaling van salicylzuur en jasmonzuur $\quad 64$

$\begin{array}{lll}6.5 & \text { Statistische analyse } & 65\end{array}$

$\begin{array}{ll}\text { Literatuur } & 66\end{array}$ 



\section{Woord vooraf}

Deze studie betreft een Privaat-Publieke Samenwerking (PPS) in het kader van de Topsector Tuinbouw \& Uitgangsmaterialen (T\&U) voor innovatiethema/koepel PPS No.2 'Het nieuwe doen in plantgezondheid'.

De deelnemende PPS-partners waren Florensis BV, Syngenta Crop Protection BV, LTO Noord Glaskracht/LTO Glaskracht Nederland, Stichting Programmafonds Glastuinbouw, Signify (voorheen: Philips Lighting), en Stichting Wageningen Research (voorheen: Stichting Dienst Landbouwkundig Onderzoek). Het project werd gefinancierd met Topsector T\&U-subsidie, en cash- en in kind-bijdragen van Florensis BV, Syngenta Crop Protection BV, LTO Noord Glaskracht/LTO Glaskracht Nederland, Stichting Programmafonds Glastuinbouw, en Signify (voorheen: Philips Lighting).

De looptijd van het project was januari 2016 - juni 2019.

De auteurs danken het kaspersoneel van de WUR-locatie te Bleiswijk voor de excellente proefondersteuning, Bert Schipper voor de planthormoonanalyses, en de projectpartners, Kirsten Leiss, Esther Meinen, Jantineke Hofland-Zijlstra, en Ric de Vos voor waardevolle discussies in de loop van het project. 


\section{Samenvatting}

In dit rapport wordt verslag gedaan van onderzoek naar de interactie tussen rood/verroodstuurlicht en inductie van plantweerbaarheid middels elicitors. Het onderzoek bestond uit een reeks min of meer uniforme kasexperimenten uitgevoerd met groepen van jonge tomatenplanten als modelgewas, aangevuld met gerbera en enkele perkplanten als sierteeltgewassen. Het beoogde weerbaarheidseffect betrof het zogenoemde systemic acquired resistance (SAR), een universeel weerbaarheidssysteem dat met name relevant is voor biotrofe pathogenen. Per experiment werden de planten gemiddeld circa vier weken onder gestandaardiseerde condities opgekweekt in een kascompartiment met LED-faciliteiten. Gedurende deze periode ondergingen de planten de voor de betreffende vraagstelling benodigde relevante behandelingen. Door toediening van elicitors werd de primings-fase geïnduceerd, en vervolgens door inoculatie met een biotroof pathogeen (echte meeldauw) de daaropvolgende fase van geïnduceerde weerbaarheid. Vanuit LED-elementen die boven de planten hingen, werden stuurlichthoeveelheden van rood (R) en verrood (FR) licht toegediend, waarbij de verhouding $R / F R$, de belichtingsduur, en de periode van belichting de variabelen waren. De effecten van de behandelingen op de SAR-expressie werden vastgesteld door (a) bepaling van het SAR-hormoon salicylzuur, en door de expressie van pathogenesis related (PR) proteins op (b) RNA-niveau (PR1) en (c) eiwitniveau (1,3-B glucanase-activiteit; PR2) te meten.

Priming middels toediening van elicitors leidde tot een significante (verhoogde) expressie van SAR(-merkers). Werkzaam waren Inssimo en 2,6-dichloroisonicotinezuur (INA). Althans in de hier gebruikte doseringen en onder de hier toegepaste condities bleken probenazole, $B$ aminoboterzuur (BABA), salicylzuur, en Hicure niet effectief voor SAR-inductie. De experimenten lieten tevens zien dat SAR-inductie niet altijd gepaard gaat met (gedeeltelijke) onderdrukking van de meeldauwontwikkeling. Behalve SAR-expressie spelen ook andere factoren een belangrijke rol voor meeldauwinfectie en -ontwikkeling. Hoewel SAR-inductie geen absolute garantie bleek voor een betere bescherming tegen het pathogeen, is het gebruik van elicitors voor de praktijk interessant omdat de meeldauwonderdrukking die hiermee bereikt kon worden substantieel was. Dat er geen effect van stuurlicht toegediend na inoculatie werd waargenomen, suggereert dat althans de meeldauwontwikkeling op zichzelf ongevoelig is voor het toegediende rode/verrode stuurlicht.

De resultaten lieten een significant stuurlicht-effect zien op de expressie van SAR(-merkers), waarbij rood stuurlicht (hoge R/FR-verhouding) in vergelijking tot verrood stuurlicht en geen stuurlicht een stimulerend effect had op SAR-expressie. Deze waarneming sluit aan bij de in de literatuur gerapporteerde rol van fytochroom bij SAR. Tevens werd waargenomen dat dit stuurlicht-effect onder de hier toegepaste condities bewerkstelligd werd in de fase voorafgaande aan de meeldauwinoculatie. Daarbij correleerde toepassing van stuurlicht vóór inoculatie in de volgorde van verrood stuurlicht - geen stuurlicht - rood stuurlicht positief met onderdrukking van meeldauw. Deze stuurlicht-effecten op SAR-expressie en meeldauwontwikkeling zijn echter aanzienlijk geringer dan de effecten bewerkstelligd door de elicitors INA en Inssimo. Er werd geen consistente interactie of synergistisch effect van het stuurlicht en de elicitors aangetoond. 


\section{$1 \quad$ Inleiding; doelstelling}

De Nederlandse tuinbouwsector heeft de ambitie om te komen tot nagenoeg emissie- en residuvrije productie met een gewasbescherming die minder afhankelijk is van chemische middelen voor de bestrijding van plantenziekten en -plagen. Algemeen wordt aangenomen dat een dergelijke gewasbescherming gezocht moet worden in een goed op elkaar afgestemd, effectief pakket van verschillende maatregelen (Integrated Pest Management, IPM). Een belangrijk onderdeel van IPM is benutting van de weerbaarheidssystemen die de plant van nature al ter beschikking staan. Deze systemen dienen in staat van paraatheid gebracht te worden op een wijze die verenigbaar is of synergie vertoont met andere onderdelen van het maatregelenpakket, en die positief bijdraagt aan het bedrijfsresultaat. Het beïnvloeden van de weerbaarheidsstatus van de plant kan in principe met fysische (bijvoorbeeld lichtbehandelingen), chemische (bijvoorbeeld natuurlijke elicitors), en microbiële middelen (bijvoorbeeld rhizobacteriën). De markt biedt uiteenlopende producten en apparatuur die hierbij van nut kunnen zijn.

De doelstelling van het project waarvan in dit rapport verslag gedaan wordt, was de interactie tussen rood/verrood-stuurlicht en inductie van plantweerbaarheid middels elicitors in kaart te brengen. Tegenover de inmiddels verworven inzichten in de mechanismen van geïnduceerde weerbaarheid staat een betrekkelijk kennishiaat over de invloed die omgevingsfactoren op het proces kunnen hebben. Verondersteld wordt dat de wisselende resultaten die chemische weerbaarheidsinductie bij de beheersing van plantenziekten in het open veld te zien geven mede met omgevingsfactoren verklaard dienen te worden. In gesloten teelten zijn de meesten daarvan tot op zekere hoogte te reguleren. Voor sessiele en fototrofe wezens als planten is licht een evident cruciale omgevingsfactor met invloed op een veelheid aan levensprocessen, waaronder de weerbaarheid tegen pathogenen. De kennisopgave die in dit kader voor ons ligt is beantwoording van de vraag hoe licht invloed uitoefent op de effectiviteit van chemische weerbaarheids-inductie bij de beheersing van plantenziekten in gesloten teelten.

In dit project is geprobeerd aan beantwoording van deze vraag bij te dragen door een reeks min of meer uniforme kasexperimenten uitgevoerd met groepen van jonge tomatenplanten als modelgewas, aangevuld met gerbera en enkele perkplanten als sierteeltgewassen. Het beoogde weerbaarheidseffect betrof het zogenoemde systemic acquired resistance (SAR), een universeel weerbaarheidssysteem dat met name relevant is voor biotrofe pathogenen; andere weerbaarheidssystemen bleven buiten beschouwing. Per experiment werden de planten gemiddeld circa vier weken onder gestandaardiseerde condities opgekweekt in een kascompartiment met LEDfaciliteiten. Gedurende deze periode ondergingen de planten de voor de betreffende vraagstelling benodigde relevante behandelingen. Door toediening van elicitors werd de primings-fase geïnduceerd, en vervolgens door inoculatie met een biotroof pathogeen (echte meeldauw) de daaropvolgende fase van geïnduceerde weerbaarheid. Vanuit LED-elementen die boven de planten hingen, werden stuurlichthoeveelheden van rood (R) en verrood (FR) licht toegediend, waarbij de verhouding $R / F R$, de belichtingsduur, en de periode van belichting de variabelen waren. De effecten van de behandelingen op de SAR-expressie werden vastgesteld door (a) bepaling van het SAR-hormoon salicylzuur, en door de expressie van pathogenesis related (PR) proteins op (b) RNA-niveau (PR1) en (c) eiwitniveau (1,3-ß glucanase-activiteit; PR2) te meten.

Hoofdstuk 2 van dit rapport geeft achtergrondinformatie over het fenomeen van geïnduceerde plantweerbaarheid en SAR, elicitors en de rol van fytochroom gerelateerd stuurlicht. Hoofdstuk 3 presenteert de onderzoeksaanpak en hoofdstuk 4 de experimentele resultaten en conclusies, gevolgd door een eindconclusie in hoofdstuk 5 en tot slot een beschrijving van de gebruikte experimentele protocollen in hoofdstuk 6. 


\section{Achtergrond; induceerbare plant- weerbaarheid, elicitors en licht}

Planten bezitten van nature breed werkende, universele afweersystemen die, zeer economisch, pas dan in de gehele plant in verhoogde staat van paraatheid gebracht worden op het moment dat zij lokaal geïnfecteerd of aangevallen wordt. Hierdoor kan zij direct met verhoogde activiteit reageren op eventuele volgende aanvallen of infecties elders in de plant. Men spreekt daarom wel van geïnduceerde (plant)weerbaarheid (induced resistance, IR; zie voor overzichtsartikelen over IR-systemen bijvoorbeeld Gozzo en Faoro (2013), Pieterse et al (2014), Conrath et al (2015)). Afhankelijk van de planthormonen die hierbij een regulerende rol spelen wordt onderscheid gemaakt tussen enerzijds systemic acquired resistance (SAR, met salicylzuurafhankelijke gen-expressie), veelal geïnduceerd door biotrofe pathogenen, en anderzijds herbivore-induced resistance (HIR, met jasmonzuur-afhankelijke gen-expressie), veelal geïnduceerd door herbivore insecten en necrotrofe pathogenen (Figuur 2.1). Beide systemen vertonen een complexe, hormoon-gereguleerde interactie (zie voor een overzicht bijvoorbeeld Robert-Seilaniantz et al, 2011). Een van SAR en HIR te onderscheiden derde IR-systeem is geïnduceerde systemische weerbaarheid (induced systemic resistance, ISR; Figuur 2.1) dat bescherming kan bieden tegen een breed scala van pathogenen en herbivoren. Induceerders van ISR zijn met name plantsymbionten zoals rhizobacteriën, en daarvan afgeleide stoffen zoals lipopolysaccharides. Niet uit te sluiten is dat er nog andere, onopgehelderde geïnduceerde weerbaarheidssystemen bestaan. De snelheid en mate waarin de inductie van het plantweerbaarheidssysteem geschiedt, wordt verondersteld beslissend te zijn voor de uiteindelijke beheersing van plaag of ziekte. De investeringen die de plant moet doen om haar afweersystemen in verhoogde paraatheid te brengen, zijn vrijwel altijd terug te zien in enige verminderde biomassa, in de literatuur vaak aangeduid als 'cost of tolerance'.

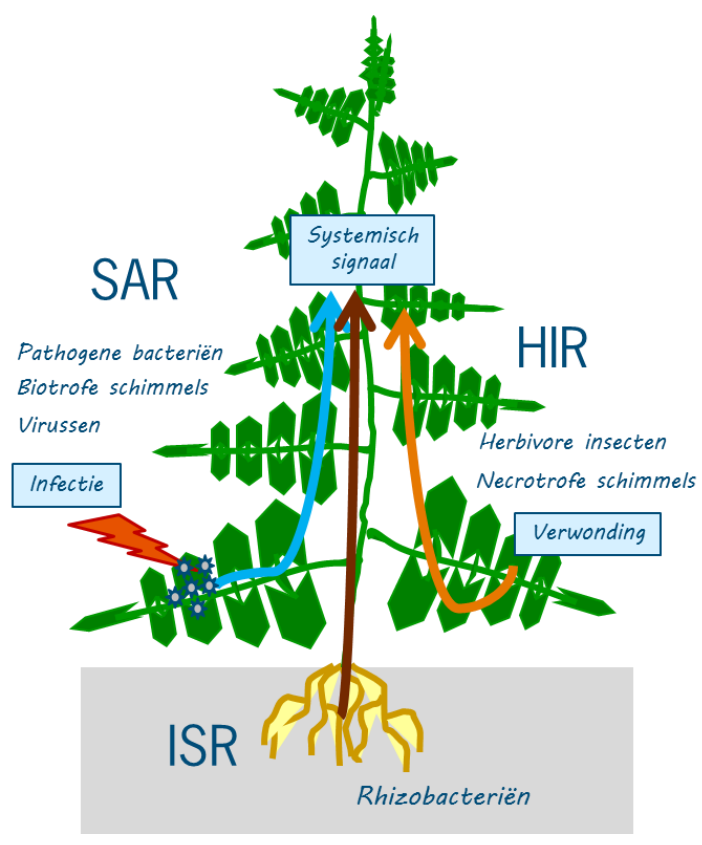

Figuur 2.1 Schematische weergave van een plant met daarin de inductie van systemic acquired resistance (SAR), herbivore-induced systemic resistance (HIR), en induced systemic resistance (ISR). Middels interne verspreiding van signaalstoffen (systemisch signaal) of middels verspreiding van signaalstoffen door de lucht worden gezonde delen van de plant in verhoogde staat van paraatheid gebracht tegen een breed scala van belagers. De systemen vertonen een complexe interactie met elkaar. 
In het geval van systemic acquired resistance (SAR) herkent de plant molecuulstructuren van pathogenen waarop via een signaalketen 'systemisch' een immuunrespons geactiveerd wordt in de onaangetaste delen van de plant, (ver) weg van de plaats van infectie. Typisch voor SAR is de gecoördineerde expressie van zogenoemde pathogenesis-related (PR) genen waarbij salicylzuur een belangrijke lokale, regulerende rol speelt. Veel van deze PR-genen coderen voor eiwitten met een antimicrobiële werking. Zo coderen $P R 2$ en $P R 3$ voor glucanases en chitinases, enzymen die de hydrolyse van celwandpolymeren van schimmels kunnen katalyseren. Figuur 2.2 geeft sterk vereenvoudigd de verschillende stappen weer van SAR. De inductie van SAR kan in beginsel vastgesteld worden aan de hand van het complex van signaalstoffen die het proces controleren (zoals salicylzuur et cetera), of meer direct door de productie te meten van effectoren die het daadwerkelijke verweer tegen het pathogeen verzorgen (zoals PR-eiwitten). Of de geproduceerde effectoren in de gegeven omstandigheden ook opgewassen zijn tegen hun taak de ziekte te beheersen, blijkt uiteindelijk uit de mate van ziekte(aantasting) van de plant.

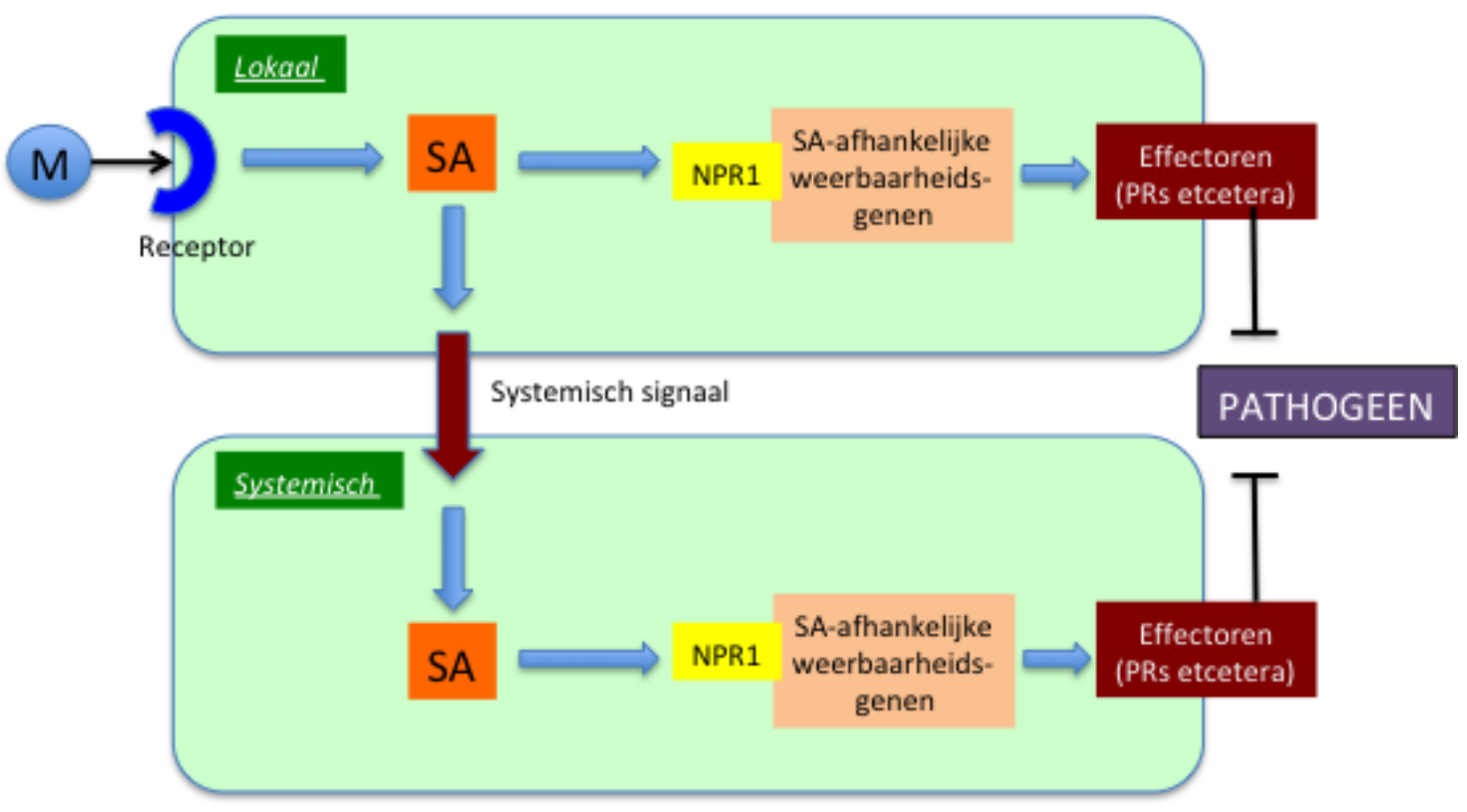

Figuur 2.2 Schematische weergave van SAR. Molecuulstructuren van pathogenen (M) worden herkend door receptoren van de plant waarop in een mede door salicylzuur (SA) gereguleerd proces lokaal weerbaarheidsgenen tot expressie komen, alsmede systemische signaalmoleculen door de plant gestuurd worden wat in gezonde plantendelen, wederom onder lokale regulatie van salicylzuur (SA), leidt tot expressie van de stoffen (zoals PR-eiwitten) die het daadwerkelijke verweer tegen het pathogeen verzorgen.

Analoog aan actieve immunisatie bij zoogdieren kan SAR ook kunstmatig geïnduceerd worden door de toediening van zogenoemde elicitors; omdat het hier om stoffen en dus niet om pathogenen gaat, spreken we van 'chemische' weerbaarheidsinductie. Chemische weerbaarheidsinductie kan het best begrepen worden door de twee procesfasen goed van elkaar te onderscheiden (Conrath et al., 2006 in Mol Plant-Microbe Interact 19:1062-1071). In de zogenoemde primings-fase, die loopt van de chemische inductie tot aan de pathogeeninfectie, wordt de plant in verhoogde staat van paraatheid gebracht, naar de laatste inzichten vermoedelijk door epigenetische aanpassingen van het chromatine. In de daaropvolgende tweede fase wordt in reactie op de pathogeeninfectie de daadwerkelijke weerbaarheid vol tot expressie gebracht. Voor de hand ligt dat celwandmoleculen van pathogenen of afgeleiden daarvan, zoals chitosan of bepaalde oligosacchariden, als elicitor kunnen fungeren, maar ook salicylzuur, dat lokaal als SAR-hormoon fungeert, kan in principe als elicitor worden toegepast. Voorbeelden van op de markt beschikbare elicitors zijn Inssimo, Vacciplant, Messenger, Stout, Oryzemate, en V-GET. Benutting van de natuurlijke afweer past in een duurzame teelt en kan bijdragen aan de terugdringing van het gebruik van pesticiden. Het gebruik van elicitors is 
vooralsnog beperkt, voornamelijk tot enkele doelgewassen, zoals rijst. In de praktijk ervaart men wisselende effectiviteit van elicitors, vermoedelijk doordat meerdere factoren een rol spelen, waaronder wisselende omgevingscondities.

Om milieuvriendelijke plantweerbaarheids-inducers een serieus alternatief te laten zijn voor fungiciden is het van belang dat hun effectiviteit ook onder praktijkcondities hoog en stabiel is. Algemeen wordt verondersteld dat de wisselende resultaten die chemische weerbaarheidsinductie bij de beheersing van plantenziekten in het open veld te zien geven door omgevingsfactoren verklaard dienen te worden (zie voor een overzicht Walters et al, 2013). In gesloten teelten zijn de meesten daarvan min of meer te reguleren. Het staat vast dat licht een fysische omgevingsfactor is die invloed heeft op de ontwikkeling van schimmelziekten in het gewas (zie voor literatuuroverzichten Roberts en Paul, 2006; Roden en Ingle, 2009; Ballaré et al, 2012; de Wit et al, 2013). Zo is bijvoorbeeld gevonden dat echte meeldauw in roos significant onderdrukt kan worden door toepassing van meer dan 22 uur licht per etmaal (Cohen en Rotem, 1970; Suthaparan et al, 2010a en 2010b). In de praktijk vindt men de hoogste infectiepercentages vaak in schaduwrijke delen van het gewas, waarbij overigens factoren als relatieve luchtvochtigheid en temperatuur ook een rol kunnen spelen.

Voor de plant fungeert licht in de eerste plaats als energiebron voor fotosynthese. Verlaging van fotosynthetisch actieve straling (PAR) gedurende de dagelijkse lichtperioden voorafgaande aan infectie bleek in diverse gewassen de vatbaarheid voor schimmelziekten te bevorderen, zoals Botrytis cinerea in tomaat (Shafia et al, 2001). In studies met alfalfa (luzerne) werd gevonden dat plantweerbaarheidssystemen die relatief veel energie vergen onderdrukt kunnen worden door limitering van PAR en koolstofassimilatie (Pennypacker, 2000). Anderzijds geldt dat een hoge productie van assimilaten met name voor biotrofe pathogenen in beginsel een gunstige factor is voor hun ontwikkeling omdat dit voor de schimmel een bron van nutriënten vormt. Een overdosis lichtenergie leidt in het blad tot schadelijke zuurstofradicalen en stress. Doorgaans reageert de plant hierop met de productie van (o.a. fenolische) metabolieten die fungeren als sunscreen en radicaal-vangers, maar waaraan ook wel antimicrobiële werking toegeschreven wordt. Met name verhoogde doseringen van UV-straling kunnen de plant aanzetten tot productie van specifieke verdedigingsstoffen, waarvan de identiteit afhangt van de genetische achtergrond van de plant (Ballaré et al, 2012).

Behalve als energiebron voor fotosynthese (assimilatielicht) gebruikt de plant licht ook als signaal voor fysiologische processen, zoals plantontwikkeling en morfologie (stuurlicht). Hiertoe beschikt de plant over lichtreceptoren voor de perceptie van specifieke lichtkwaliteiten; fytochroom detecteert rood (600-700 nm) en verrood-licht (700-800 nm), cryptochroom en fototropines detecteren blauw en UV-A licht tussen 320 en $500 \mathrm{~nm}$, en UV-B fotoreceptoren detecteren UV-B tussen 280 en 315 nm (Ballaré et al, 2012; Jenkins et al, 2001).

De literatuur wijst met name op een relatie tussen rood licht en plantweerbaarheid. Islam et al $(2002,1998)$ lieten zien dat de weerbaarheid van paprika, pompoen en tomaat geïnduceerd kan worden door toepassing van rood licht; de weerbaarheid van tuinboon tegen Botrytis cinerea nam onder invloed van rood licht toe, vermoedelijk door inductie van de productie van natuurlijke fungiciden. Rood en verrood licht bleken tegengestelde effecten te hebben op de onderdrukking van echte meeldauw in komkommer (Schuerger en Brown, 1997). Wang et al (2010) zagen dat planten geteeld onder rood licht resistenter waren tegen echte meeldauw dan de controlegroepen, en verhoogde gehaltes waterstofperoxide, salicylzuur en PR1 eiwit bevatten. Het is algemeen bekend dat schimmelziekten in de schaduw beter gedijen dan in direct licht; mogelijk heeft dit te maken met een lage rood/verrood-verhouding in de schaduw, die door de plant gedetecteerd wordt door haar fytochroom. In Arabidopsis is met phyA- en phyB-mutanten gevonden dat SAR-regulatie door salicylzuur (SA) afhankelijk is van signaalroutes die onder controle staan van fytochroom; de SA-gereguleerde PR-expressie bleek strikt afhankelijk te zijn van licht (Genoud et al 2002). Voorts bleek in Arabidopsis dat de SARrespons op het pathogeen Pseudomonas syringae binnen een vast dag/nacht-regime een ritmiek vertoont; wanneer de plant in de ochtend met het pathogeen in contact komt is de weerbaarheidsrespons significant hoger dan in de middag. In de donkerperiode is de respons het laagst. De onderzoekers concludeerden dat hoe langer de lichtperiode na inoculatie duurde, des te hoger de respons; kortom, een lichtafhankelijkheid in plaats van een circadiaanse ritmiek 
(Griebel \& Zeier, 2008). Bovengenoemde lichtafhankelijkheid bleek (mede) gereguleerd te worden door fytochroom, en niet door een ander type lichtreceptor (Griebel \& Zeier, 2008).

Enige jaren geleden werd door onderzoekers van Wageningen UR in een experiment met jonge tomatenplanten waargenomen dat de biosynthese van het SAR-hormoon salicylzuur onder normale lichtcondities niet geïnduceerd werd door de elicitor 2,6-dichloro-isonicotinezuur (INA), maar dat dit wel het geval was bij een verhoogde rood/verrood-verhouding van het toegediende licht (SA-gehaltes varierend van $\mathrm{ng}$ tot enkele $\mu \mathrm{g}$ per $\mathrm{g}$ versgewicht plantmateriaal), en dat dit zich vertaalde in een substantieel verhoogde SAR-respons (vastgesteld door monitoring van de activiteit van de SAR-merker PR2). Deze waarnemingen suggereren dat de effectiviteit van elicitors van SAR mogelijk gecontroleerd kan worden met rood stuurlicht. 


\section{Onderzoeksvragen en onderzoeks- aanpak; afbakening}

De hierboven (hoofdstuk 2) genoemde relatie tussen fytochroom en systemic acquired resistance (SAR) roept de vraag op of de effectiviteit van chemische elicitors beïnvloed kan worden met rood en verrood stuurlicht. Dat is de centrale onderzoeksvraag van dit project: is er een interactie tussen rood/verrood-stuurlicht en chemische elicitatie van SAR? En zo ja, kan deze in de praktijk benut worden voor het verkrijgen van een stabiele effectiviteit van elicitors en aldus een rol spelen in IPM?

Om die eventuele interactie boven water te krijgen dienen de juiste stuurlichtbehandelingen op het juiste moment toegediend te worden, in combinatie met de juiste elicitor.

Omdat het om een verondersteld fytochroom-effect gaat, zijn de experimenten uitgevoerd met LED-modules die lage hoeveelheden rood $\left(5 \mu \mathrm{mol} . \mathrm{s}^{-1} \cdot \mathrm{m}^{-2}\right.$ op pothoogte) en lage hoeveelheden verrood licht ( $50 \mu \mathrm{mol} . \mathrm{s}^{-1} \cdot \mathrm{m}^{-2}$ op pothoogte) uitzonden. Ongeveer $10 \%$ van het verrode licht is door de plant voor fotosynthese te benutten; om die hoeveelheid gelijk te trekken met die van het rode licht werd $50 \mu \mathrm{mol} . \mathrm{s}^{-1} . \mathrm{m}^{-2}$ verrood licht toegediend. De LED-modules bevonden zich boven de planten.

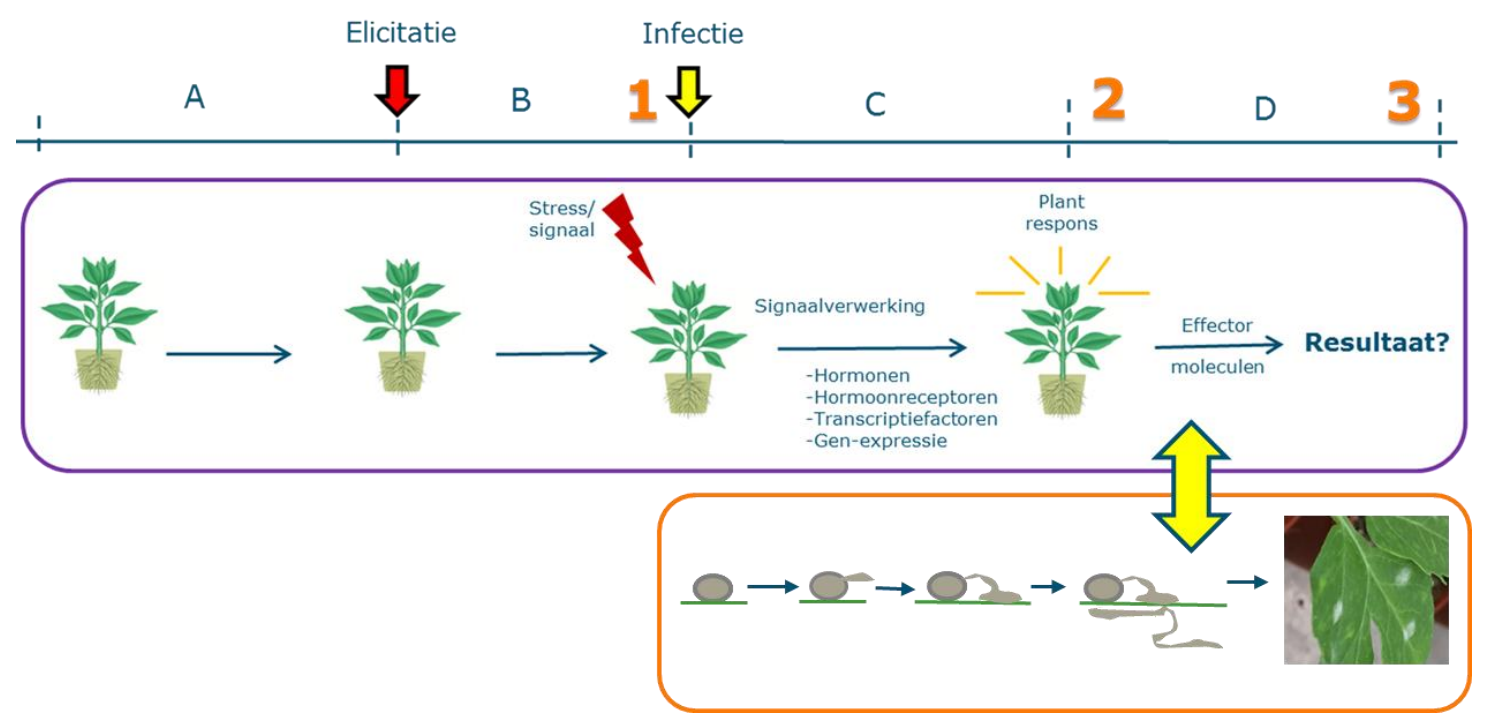

Figuur 3.1 Een plant die behandeld wordt met een elicitor en vervolgens in contact komt met een pathogeen doorloopt een proces (paars omcirkeld) dat in vier fasen onderverdeeld kan worden, die elk aan fytochroomregulatie onderhevig kunnen zijn. Het pathogeen doorloopt vanaf de infectie eveneens een ontwikkelingsproces (geel omcirkeld) dat mogelijk interactie met stuurlicht vertoont. De experimenten waren min of meer uniform opgezet volgens dit model. Cijfer 1 geeft het moment van eerste bladmonstername weer (' $\left.T=0^{\prime}\right)$, en cijfer 2 het moment van tweede bladmonstername (' $T=1$ '). Cijfer 3 geeft het moment weer waarop de meeldauwschade en fysiologische parameters zoals plantlengte bepaald werden.

Wat betreft de juiste timing van de stuurlichtbehandelingen: hoe lang en gedurende welke periode van de dag/nacht-cyclus moet belicht worden, en is het ontwikkelingsstadium van de plant relevant? Veel fundamentele kennis over werkingsmechanismen is vergaard met proeven in klimaatkamers, ingericht met kunstlicht van specifieke lichtkwaliteit. Om dicht bij de praktijk 
te blijven, zijn de experimenten van dit project uitgevoerd in een kascompartiment onder daglicht, eventueel aangevuld met kunstlicht. De momenten dat het stuurlicht qua intensiteit niet overstegen wordt door deze PAR-lichtbronnen vallen logischerwijze in de donkerperiode. Daarom is er voor gekozen om de stuurlichtbehandelingen vanaf zonsopkomst of vlak voor zonsondergang aan te zetten en na zonsondergang (en na uitschakeling van eventueel kunstlicht) door te laten lopen tot in de donkerperiode en voor middernacht uit te schakelen; in experimenten met additioneel blauw licht werd continue stuurlichtbehandeling toegepast. Dit betekent dat het rood/verrood-signaal tenminste gedurende enkele uren per etmaal na zonsondergang aanwezig was. Om te controleren of het gewas ook werkelijk een fytochroomeffect ervaren had, werden plantlengtemetingen uitgevoerd. Als modelgewas is gekozen voor tomaat (cv Komeett); om praktische redenen beperkte het onderzoek zich tot jonge planten (tot en met circa 2 maanden na zaaien). Tevens werden enkele experimenten uitgevoerd op gerbera en enkele perkplanten. De keuze van elicitor hangt af van het weerbaarheidssysteem dat geïnduceerd moet worden in samenhang met het te beheersen pathogeen. Dit onderzoek betreft systemic acquired resistance (SAR) dat met name gericht is tegen biotrofe schimmels; de biotrofe schimmel echte meeldauw is in diverse gewassen een groot probleem. In ons modelsysteem gaat het om tomaat en Oidium neolycopersici. Op basis van eerder onderzoek werd de experimentele elicitor 2,6-dichloro isonicotinezuur (INA) als positieve controle gebruikt, naast andere elicitors.

Wanneer de plant een elicitor-behandeling ondergaat en vervolgens strijd levert met een pathogeen, kunnen chronologisch vier toestanden van de plant of procesfases onderscheiden worden, namelijk (A) de fase waarin de plant zich bevindt voorafgaande aan elicitatie, (B) de fase die opgeroepen wordt door de elicitor, ook wel primings-fase genoemd, (C) de fase waarin de plant in reactie op het pathogeen daadwerkelijk haar weerbaarheidssysteem vol tot expressie brengt, en (D) de fase waarin de plant de strijd ondergaat met het zich al dan niet binnendringende pathogeen (Figuur 3.1).

Elk van deze vier fasen zou in theorie op verschillende wijze gereguleerd kunnen zijn door fytochroom. Zo zou de receptiviteit voor elicitors in fase A wellicht door rood licht gestuurd kunnen worden, of is het primings-proces zelf (fase B) van de rood/verrood-verhouding afhankelijk. Hetzelfde zou kunnen gelden voor fasen $C$ en D. Merk op dat bij deze laatste fasen het systeem gecompliceerd wordt door de aanwezigheid van het pathogeen; niet uit te sluiten is dat het stuurlicht eventueel directe werking heeft op het pathogeen of op de interactie tussen plant en pathogeen (Figuur 3.1).

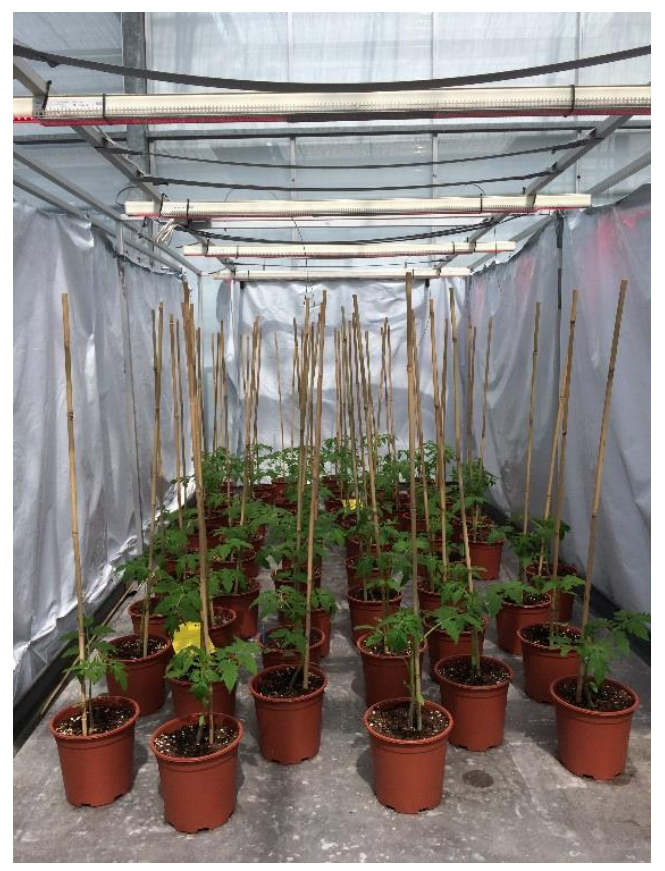

Figuur 3.2 Groep tomatenplanten onder LED-modules bij aanvang van een experiment. 
De opzet van de experimenten was min of meer uniform en gebaseerd op dit model (Figuur 3.1). In een kascompartiment werden jonge planten in afzonderlijke groepen opgekweekt, met boven elke groep LED-modules die al dan niet het relevante stuurlicht uitzonden (fase A; Figuur 3.2). Op zeker moment werd een deel van de planten eenmalig met elicitor behandeld (bladbespuiting), waarmee de primings-fase (fase B) aanving. Na 3-4 dagen werd het hele gewas uniform geïnoculeerd middels een bladbespuiting met vers gesuspendeerde conidia van echte meeldauw, waarmee fase $C$ aanving. Om de SAR-respons te kunnen volgen werden op twee momenten (zie Figuur 3.1) boven in de plant uniform uit de eerste, volledig ontvouwen samengestelde bladeren bladmonsters genomen, waaraan hormoonbepalingen en expressie van PR1 en PR2 gemeten konden worden. Het uiteindelijke resultaat van het hele proces in termen van meeldauwbeheersing kon circa 11 dagen na meeldauwinoculatie worden vastgesteld aan de hand van de ontwikkelde mycelium-bladbedekking (het 'wit'). De groepen planten waren van elkaar afgeschermd met lichtdicht folie. De planten bevonden zich in individuele potten met potaarde, zodat ze, afhankelijk van de proefopzet, tussentijds onder ander LED-modules geplaatst konden worden. Eveneens afhankelijk van de proefopzet werden LED-modules tussentijds uitgeschakeld. De elicitor INA werd bij tomaat steeds lokaal toegediend op de twee onderste echte bladeren, zodat de bovenin de plant waargenomen SAR-respons een systemisch effect betreft.

SAR kenmerkt zich door de expressie van pathogenesis related (PR) eiwitten. In dit project werd de expressie van PR1 en PR2 gebruikt als maat voor SAR. PR2 vertoont 1,3-B glucanaseactiviteit (EC 3.2.1.6) en is dus in beginsel in bladmateriaal te kwantificeren door hieruit eiwitextracten te bereiden en daarin vervolgens de glucanase-activiteit te bepalen. In dit project werd een enzym-assay gebruikt met het natuurlijke suikerpolymeer laminarine als substraat. PR1 bezit geen enzymactiviteit. Voor de bepaling van PR1-expressie werd voor het modelgewas tomaat een RNA-assay ontwikkeld waarmee één specifiek PR1-gen gekwantificeerd werd ten opzichte van twee huishoudgenen. Merk op dat de gebruikte enzym-assay voor PR2 niet noodzakelijk het product van één gen aantoont, maar alle genproducten die 1,3-ß glucanaseactiviteit vertonen, en in principe gebruikt kan worden voor de bepaling van PR2 in uiteenlopende gewassen. De PR1-assay is gericht op één specifiek gen uit tomaat. 


\section{De experimenten}

\subsection{Vergelijking van elicitors onder rood en verrood stuurlicht}

\subsubsection{Inleiding}

Het eerste kasexperiment betrof het onder rood/verrood stuurlicht toetsen van een set elicitors die in de literatuur beschreven zijn als inducers van SAR. Hiertoe werd een set elicitors geselecteerd die vanwege hun complementariteit toegepast in hetzelfde experiment mechanistische kennis zou kunnen opleveren over de veronderstelde interactie tussen SAR en fytochroom. Om die reden is gekozen uit (eventueel geformuleerde) zuivere actieve stoffen die een bewezen relatie met SAR hebben, en zijn de vele ongedefinieerde mengsels van natuurproducten (algenextracten et cetera) buiten beschouwing gelaten. De onderstaande zes elicitors werden geselecteerd.

1. 2,6-Dichloro-isonicotinezuur (INA). De experimenten waarmee een interactie tussen fytochroom en elicitatie van systemic acquired resistance (SAR) werd waargenomen, zijn indertijd uitgevoerd met de elicitor 2,6-dichloro-isonicotinezuur (INA). Daarom gebruiken we INA als positieve controle.

2. Inssimo. De actieve component van het product Inssimo (Syngenta) is benzothiadiazole (BTH). Er zijn aanwijzingen dat BTH in de plant wordt omgezet in acibenzolar (AB) en dat deze stof de daadwerkelijke SAR-inducer is (Tripathi et al, 2010). Literatuurgegevens wijzen uit dat BTH SAR induceert zonder de accumulatie van salicylzuur (SA) (Friedrich et al, 1996, Plant J. 10: 61-70); omdat BTH ook PR-expressie kan induceren in mutanten die gemankeerd zijn in hun SA-biosynthese (Lawton et al, 1996), lijkt BTH (of AB) actief te zijn downstream van SA. Omdat deze karakteristieken overeenkomen met die van INA (Vernooij et al, 1995) verwachten we het fytochroom-effect ook terug te zien bij Inssimo. Inssimo is dus een zeer interessante kandidaat om in de experimenten mee te nemen.

3. Probenazole (PBZ). Voor de studie van het mechanisme is het interessant om ook elicitors te kiezen die mogelijk aangrijpen op andere punten in de signaaltransductieketen. In tegenstelling tot INA en BTH lijkt probenazole (PBZ, de actieve component uit het vooral op rijst toegepaste product Oryzemate) upstream van SA te werken: PBZ induceert PR- én SAexpressie, en anders dan INA en BTH zou PBZ niet in staat zijn PR-expressie te induceren in Arabidopsis-mutanten met een gemankeerde SA-biosynthese (zie bijvoorbeeld Yoshioka et al, 2001).

4. B-Aminoboterzuur (BABA) is interessant omdat het als primer optreedt bij zeer diverse weerbaarheidsreacties die zowel door SA-afhankelijke als door SA-onafhankelijke signaaltransductieketens gecontroleerd worden; het is bekend dat BABA bescherming biedt tegen een breed spectrum van biotische en abiotische stress (zoals microbiële pathogenen, insectenvraat, droogte- en zoutstress). Bovendien is de BABA-receptor voor SAR-inductie inmiddels geidentificeerd; deze werkt downstream van SA (Luna et al, 2014; Ton et al, 2005).

5. Salicylzuur (SA). Bovengenoemde set elicitors bevat een stof die upstream en stoffen die downstream van salicylzuur (SA) werken. Lokaal is SA het sleutelmolecuul in de SARregulatie en kan dus in beginsel ook als elicitor fungeren.

6. Hicure. Waarnemingen bij gerbera uitgevoerd door WUR laten zien dat de weerbaarheidsbevorderende activiteit van het product Hicure (Syngenta) waarschijnlijk niet via inductie 
van SAR verloopt. Hicure kan daarom in deze proefopzet fungeren als negatieve controle: indien er inderdaad sprake is van een specifieke interactie tussen fytochroom en SARinductie mag een verhoogde rood/verrood-ratio hier geen inductie van PR-expressie te zien geven.

\subsubsection{Uitvoering van het experiment}

Het experiment vond plaats in augustus/september 2016 in een groot kascompartiment (144 $\mathrm{m}^{2}$ ) van Wageningen UR op locatie Bleiswijk. Jonge tomaten- en gerberaplanten werden elk in afzonderlijke potten op eb- en vloedtafels geplaatst; per tafel een groep van tenminste 27 tomatenplanten (cv Komeett, gezaaid) en een groep van tenminste 27 gerberaplanten (kleurmix jonge stekjes van JHL group, fungicide en zwavelvrije opkweek). Elke tafel onderging gedurende de dagperiode en een deel van de donkerperiode(van 7:00 tot 23:00 uur) een rood (5 $\mu \mathrm{mol}^{-\mathrm{s}^{-}}$ $\left.{ }^{1} . \mathrm{m}^{-2}\right)$, verrood $\left(50 \mu \mathrm{mol} . \mathrm{s}^{-1} \cdot \mathrm{m}^{-2}\right)$ of geen stuurlichtbehandeling, die werden toegediend vanuit LED-modules die zich 2 meter boven elke tafel bevonden. Daglicht werd op donkere dagen $\left(<200 \mu \mathrm{mol} . \mathrm{s}^{-1} \cdot \mathrm{m}^{-2}\right)$ aangevuld met $12 \mathrm{SON}-\mathrm{T}$ lampen $\left(100 \mu \mathrm{mol} . \mathrm{s}^{-1} \cdot \mathrm{m}^{-2} ; 7000-10000\right.$ lux van 7:00 tot 23: uur). Temperatuurinstellingen waren $20^{\circ} \mathrm{C}$ van 9:00-18:00 uur en $17{ }^{\circ} \mathrm{C}$ van 18:00 -9:00 uur). RV was 70\%. Middels eb en vloed werd standaard nutriëntenvoeding voor tomaat toegediend en bevochtigd. Vijf dagen na de start van de LED-belichting werden de zes hierboven beschreven elicitors toegediend (twee bladeren onderin de plant). De spuitconcentraties waren $1 \mathrm{mM} \mathrm{2,6-dichloro} \mathrm{isonicotinezuur} \mathrm{(INA),} 5 \mathrm{mM}$ B-aminoboterzuur (BABA), $0.5 \mathrm{mM}$ salicylzuur (SA), $0.2 \mathrm{mM}$ probenazole (PBZ), 0.125\% (v/v) Hicure, en, 0.005\% $(w / v)$ Inssimo. Van elke groep werden setjes van drie planten behandeld met één elicitor (per tafel en plantensoort in totaal zes elicitors); een setje van drie planten van elke groep bleef steeds onbehandeld (onbehandelde controle-groepen). Op deze wijze werden combinaties gecreëerd van 7 elicitor-behandelingen (incl. onbehandelde controle) en 3 lichtbehandelingen (inclusief controle). Drie dagen na toediening van de elicitors werden de planten 's middags geïnoculeerd met een vers bereide suspensie van meeldauwsporen (ca. $10^{4}$ conidia/ml voor tomaat, en ca $10^{5}$ conidia/ml voor gerbera), waarna de RV gedurende 24 uur op $90 \%$ werd gehouden. De meeldauw-suspensies werden bereid uit het mycelium van door echte meeldauw aangetaste tomaten en gerberaplanten en werden binnen circa 30 minuten na bereiding middels bespuiting op het gewas gebracht. In de ochtend van de dag voorafgaande aan de dag van meeldauwinoculatie werden de planten uniform bemonsterd ( $T=0$-bemonstering). Vijf dagen later werden ze in de ochtend opnieuw uniform bemonsterd ( $T=1$-bemonstering). De monsters werden onmiddellijk ingevroren in vloeibare stikstof en bewaard bij $-80^{\circ} \mathrm{C}$ tot aan de verwerking voor analyse van PR1, PR2 en salicylzuur. Op de dag na de laatste monstername werden aan 3 onbemonsterde, ongeeliciteerde tomatenplanten per tafel SPAD-metingen (Minolta SPAD 502 PlusChlorofyl Meter) en lengtemetingen verricht. In dit experiment was gericht op de SAR-expressie; er zijn geen analyses uitgevoerd van de meeldauwschade. Het experiment werd uitgevoerd in 3-voud.

\subsubsection{Resultaten en conclusies}

De planten waren blootgesteld aan (1) verschillende stuurlichtbehandelingen, (2) verschillende elicitors, en (3) aan meeldauw. In tomaat leidde de meeldauw-inoculatie in alle groepen tot waarneembare infecties. Figuur 4.1 toont het effect van de stuurlichtbehandelingen op de lengte van de tomatenplanten na afloop van het experiment. De significante lengtetoename van de met verrood behandelde groepen ten opzichte van de controle-groepen laat zien dat het verrood licht daadwerkelijk werkzaam geweest is op fytochroom met de te verwachten strekking van de planten tot gevolg. Ook de verschillen in chlorofylgehalte gemeten aan drie bladetages onderin de tomatenplanten (Figuur 4.2) lieten met een verlaagd chlorofylgehalte een significant verrood-effect zien. De rood-behandelingen bleken echter geen significant effect te vertonen op beide fysiologische parameters (Figuur 4.1 en 4.2 ). 


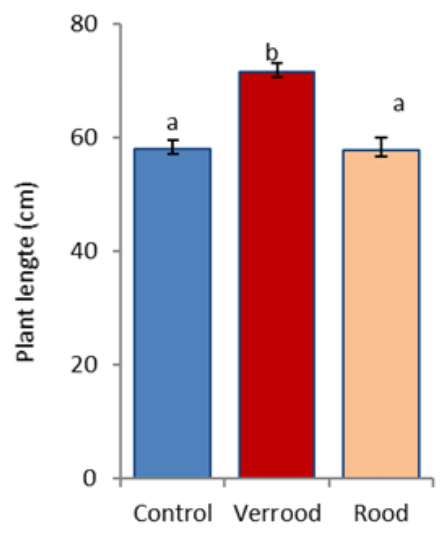

Figuur 4.1 Gemiddelde lengte van de groepen tomatenplanten die zonder stuurlicht, onder verrood stuurlicht en onder rood licht opgroeiden. Kolommen aangeduid met verschillende letters zijn significant verschillend.

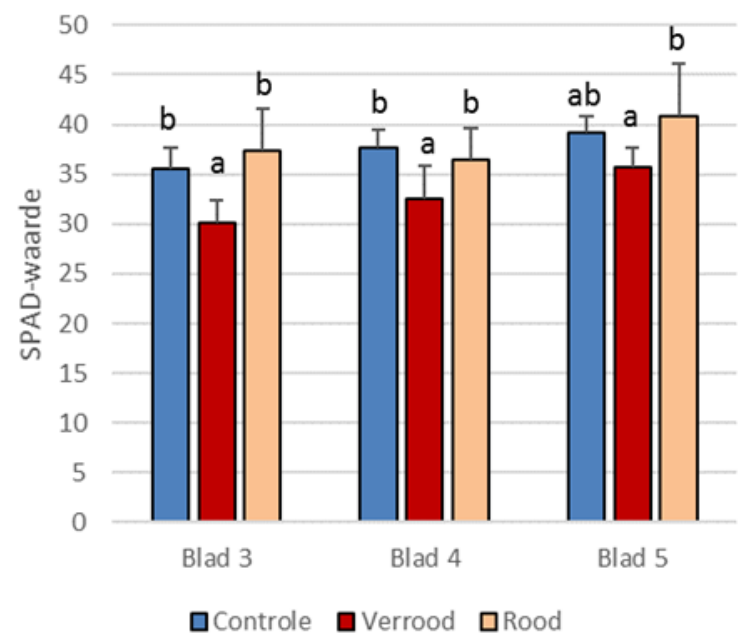

Figuur 4.2. Relatief chlorofylgehalte uitgedrukt in SPAD-waarden gemeten aan drie bladetages (genummerd vanaf de cotylen) van de groepen tomatenplanten die zonder stuurlicht, onder verrood stuurlicht en onder rood licht opgroeiden. Kolommen aangeduid met verschillende letters zijn significant verschillend.

Figuur 4.3 toont hoe de tomatenplanten onder de drie belichtingscondities op de verschillende elicitors reageerden in termen van PR2-expressie (glucanase-activiteit); de linkerfiguur toont de PR2-expresie vóór $(T=0)$ en de rechterfiguur na $(T=1)$ meeldauwinfectie. Vóór meeldauwinfectie $(T=0)$ lag de glucanase-activiteit in alle gevallen op een laag basis-niveau met slechts subtiele onderlinge verschillen, waarbij echter wel een significant LED-effect (hoogste PR2-niveaus onder verrood, laagste onder rood licht) en een significant elicitor-effect (hoogste PR2-niveaus met INA en Inssimo) werden waargenomen. Na meeldauwinfectie $(T=1)$ vertoonden de planten die met INA en met Inssimo behandeld waren een sterk en significant verhoogde expressie van deze SAR-merker; er werd geen significant LED-effect gevonden (Fpr. 0.079). De overige groepen lieten na meeldauwinfectie slechts een zeer lichte stijging van PR2 zien (Figuur 4.3). Elicitor- en LED-behandelingen vertoonden geen interactie (Fpr. 0.99). 

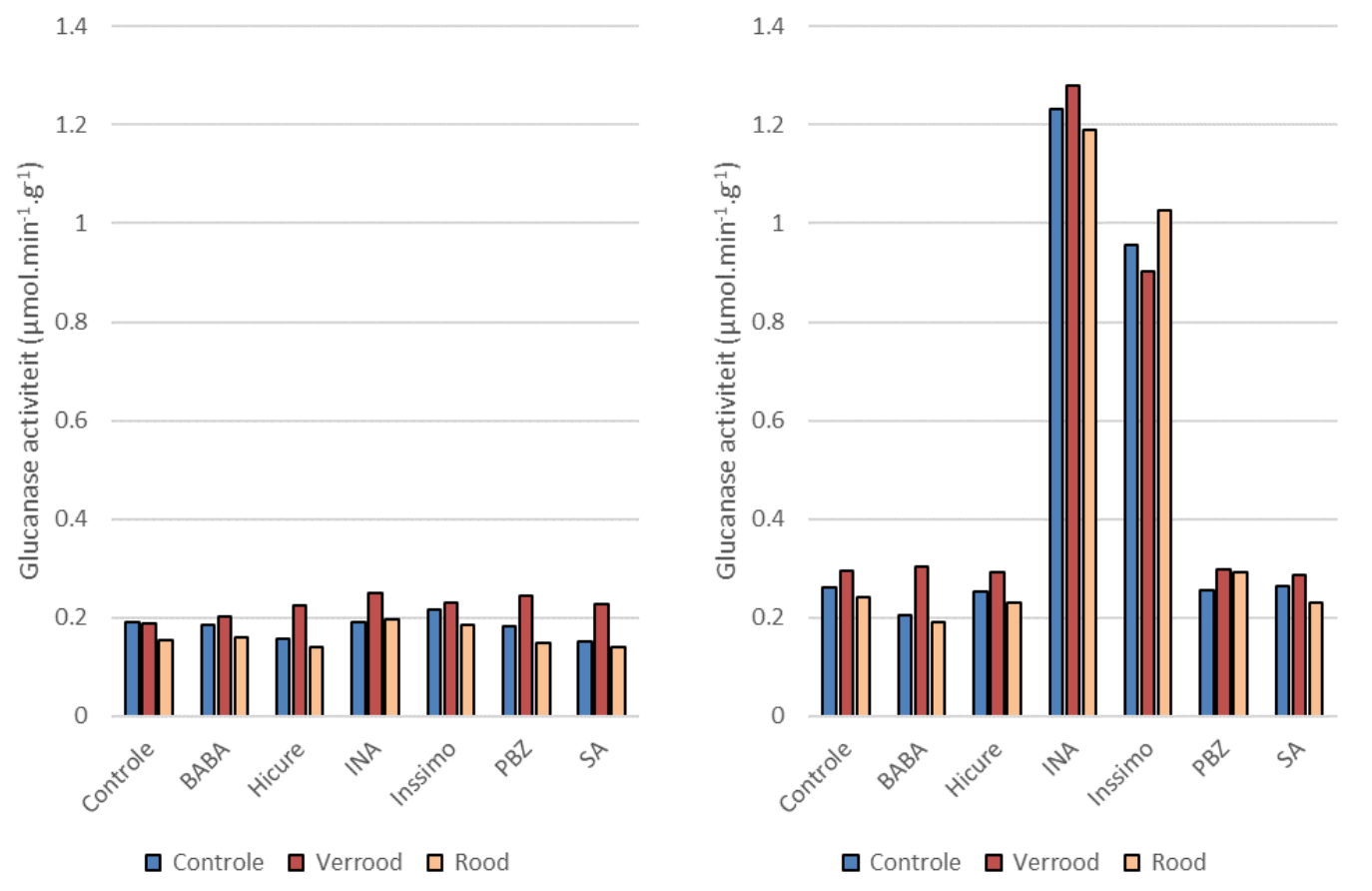

Figuur 4.3 De $\beta$-1,3-glucanase activiteit in de verschillende groepen tomatenplanten bepaald vóór meeldauwinfectie $(T=0$; linkerfiguur; $L s d=0.056)$ en na meeldauwinfectie $(T=1$; rechterfiguur; $L s d=0.109) . n=3$.

Figuur 4.4 toont de relatieve hoeveelheid van het gemeten PR1-RNA op T=1 (na meeldauwinoculatie) ten opzichte van $\mathrm{T}=0$ (vóór meeldauwinoculatie), waarbij genormaliseerd is ten opzichte van de expressie van het 'huishoudgen' L33 (Figuur 4.4 links) en het 'huishoudgen' Ef1a (Figuur 4.4 rechts) die algemeen verondersteld worden een constant expressieniveau te bezitten. Gemeten ten opzichte van L33 werd gemiddeld een lichte afname van PR1 waargenomen (Fig 4.4 links); gemeten ten opzichte van Ef1a werd slechts gemiddeld een verdubbeling van PR1-expressie vastgesteld (Figuur 4.4 rechts), zonder significante LED- of elicitoreffecten. Deze data wijzen erop dat geen van de behandelingscombinaties leidde tot een PR1-inductie van betekenis.

\section{L33}

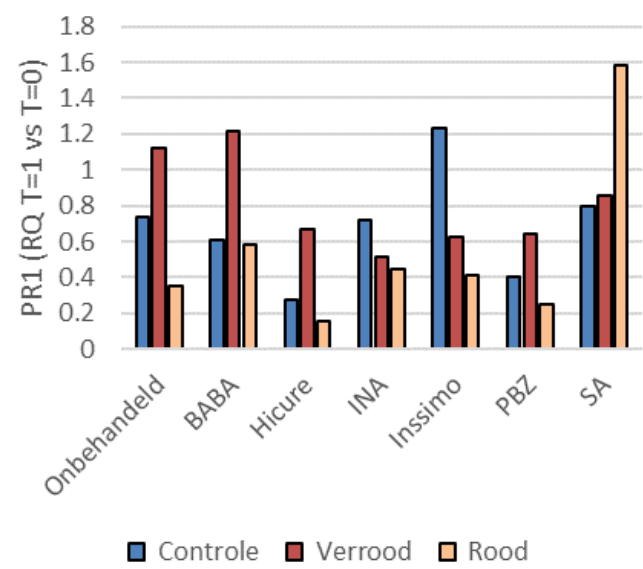

Ef1a

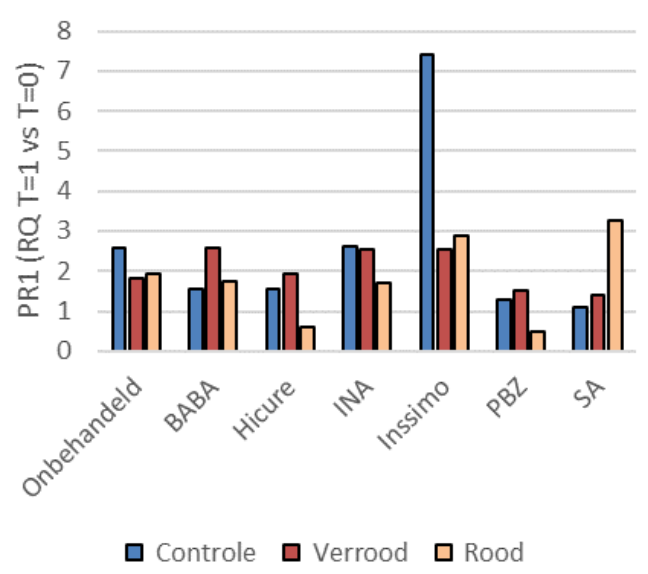

Figuur 4.4 Relatieve hoeveelheid PR1-expressie (RNA) op $T=1$ (na meeldauwinoculatie) ten opzichte van $T=0$ (vóór meeldauwinoculatie), waarbij genormaliseerd is ten opzichte van de expressie van het 'huishoudgen' L33 (Figuur 4.4 links; Lsd L33 = 0.71) en het 'huishoudgen' Ef1a (Figuur 4.4 rechts; $L s d=3.60$ ). $n=2$. 

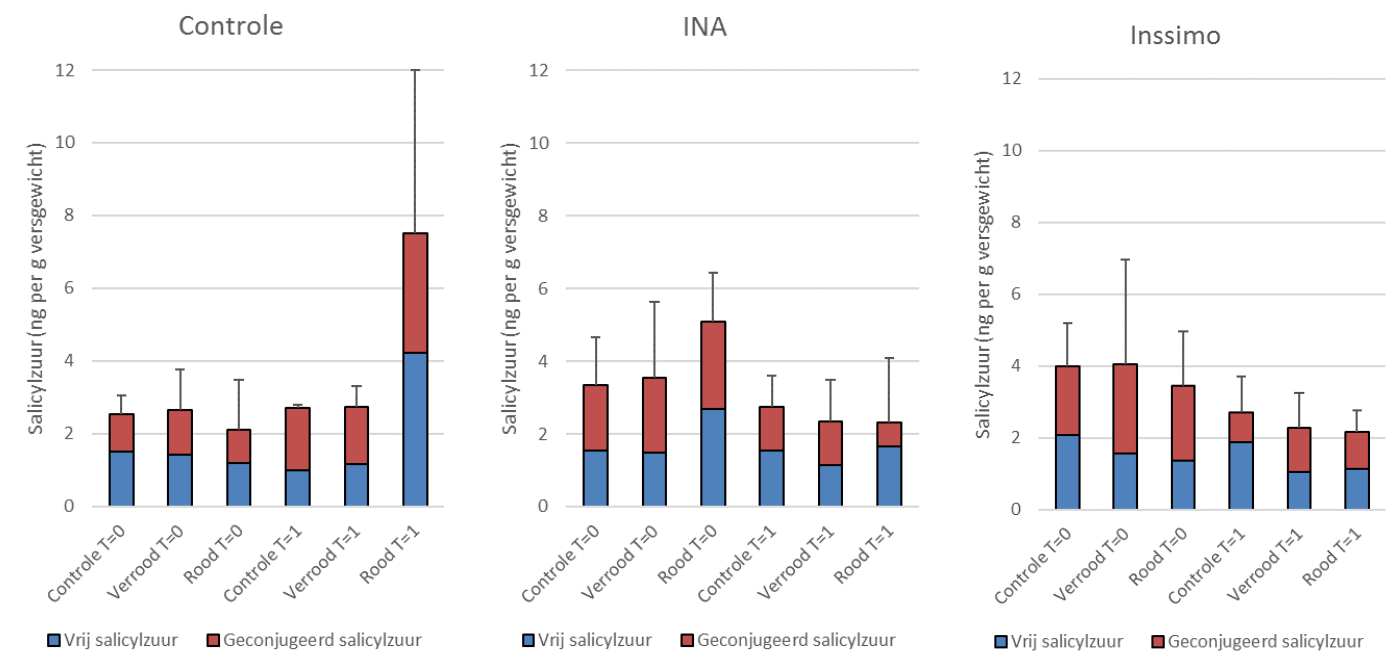

Figuur 4.5 Gehalte vrij salicylzuur (SA; Isd=1.37) en geconjugeerd $S A(I s d=1.90)$ in de onbehandelde controlegroepen, en de met INA en Inssimo behandelde groepen tomatenplanten. De streepje boven de kolommen geven de standaardafwijking weer van de totaalsom vrij en geconjugeerd SA. $n=3$.

Het hormoon salicylzuur (SA) reguleert lokaal de expressie van SAR-genen (zoals PR-eiwitten). Omdat sterke inductie van PR2 was waargenomen bij de tomatenplanten die met INA en Inssimo behandeld waren (Figuur 4.3), werd van deze groepen en van de onbehandelde controlegroepen de SA-gehaltes bepaald. Behalve middels directe biosynthese kan de plant de SA-gehaltes ook reguleren door het actieve, vrije SA om te zetten naar geconjugeerd SA (meestal geconjugeerd met suikergroepen), of omgekeerd, door SA vrij te maken uit geconjugeerd SA. In dit experiment werd zowel het vrije als het geconjugeerde SA bepaald. Figuur 4.5 toont de resultaten. Opmerkelijk is dat de absolute SA-gehaltes in alle gevallen betrekkelijk laag zijn (enkele ng per g versgewicht); in het verleden zijn circa 100-voudige hoeveelheden waargenomen in met echte meeldauw geïnoculeerde tomatenplanten die met INA behandeld waren. Voor de meeste monsters was de verhouding vrij SA en geconjugeerd SA ongeveer $1: 1$. Het gehalte vrij SA was voor INA en Inssimo na meeldauwinfectie $(T=1)$ niet hoger dan vóór meeldauwinfectie $(T=0)$, en ook niet significant hoger dan de gehaltes gemeten in de elicitor-controlegroep (Figuur 4.5). Hieruit blijkt dat de PR2 expressie niet direct gekoppeld is aan louter het gehalte vrij SA.

De assay voor PR2 is in tegenstelling tot de gewasspecifieke PR1-assay een enzymactiviteitsbepaling en kan daarom in beginsel toegepast worden bij andere gewassen dan tomaat. Figuur 4.6 toont de PR2-expressie in de verschillende gerberagroepen onder de drie belichtingscondities en na toediening van de verschillende elicitors; de linkerfiguur toont de PR2-expresie vóór meeldauwinoculatie $(T=0)$ en de rechterfiguur na meeldauwinoculatie $(T=1)$. Terwijl de meeldauwontwikkeling in de tomatenplanten probleemloos verliep, werd in geen van de groepen gerbera-planten ontwikkeling van meeldauw vastgesteld. Vergeleken met tomaat werden relatief lage PR2 expressie-niveaus waargenomen. Wellicht moet dit verklaart worden met een zwak aangeslagen meeldauwinoculatie bij gerbera. Niettemin vertoonden alle gerberagroepen een significante toename in PR2-activiteit na meeldauwtoediening ( $T=1$ t.o.v. $\mathrm{T}=0 ; \mathrm{Fpr}<0.001$ ). Tevens werd er een significant elicitor-effect vastgesteld (Fpr. 0.011); evenals bij tomaat was PR2-inductie na meeldauwinoculatie het sterkst bij de groepen die behandeld waren met INA en Inssimo. Ook was er een significant LED-effect (Fpr. 0.001), met gemiddeld, dus los van INA en Inssimo, de sterkste inductie in de LED-controle-groepen (Figuur 4.6). Er werden geen significante interacties vastgesteld. 

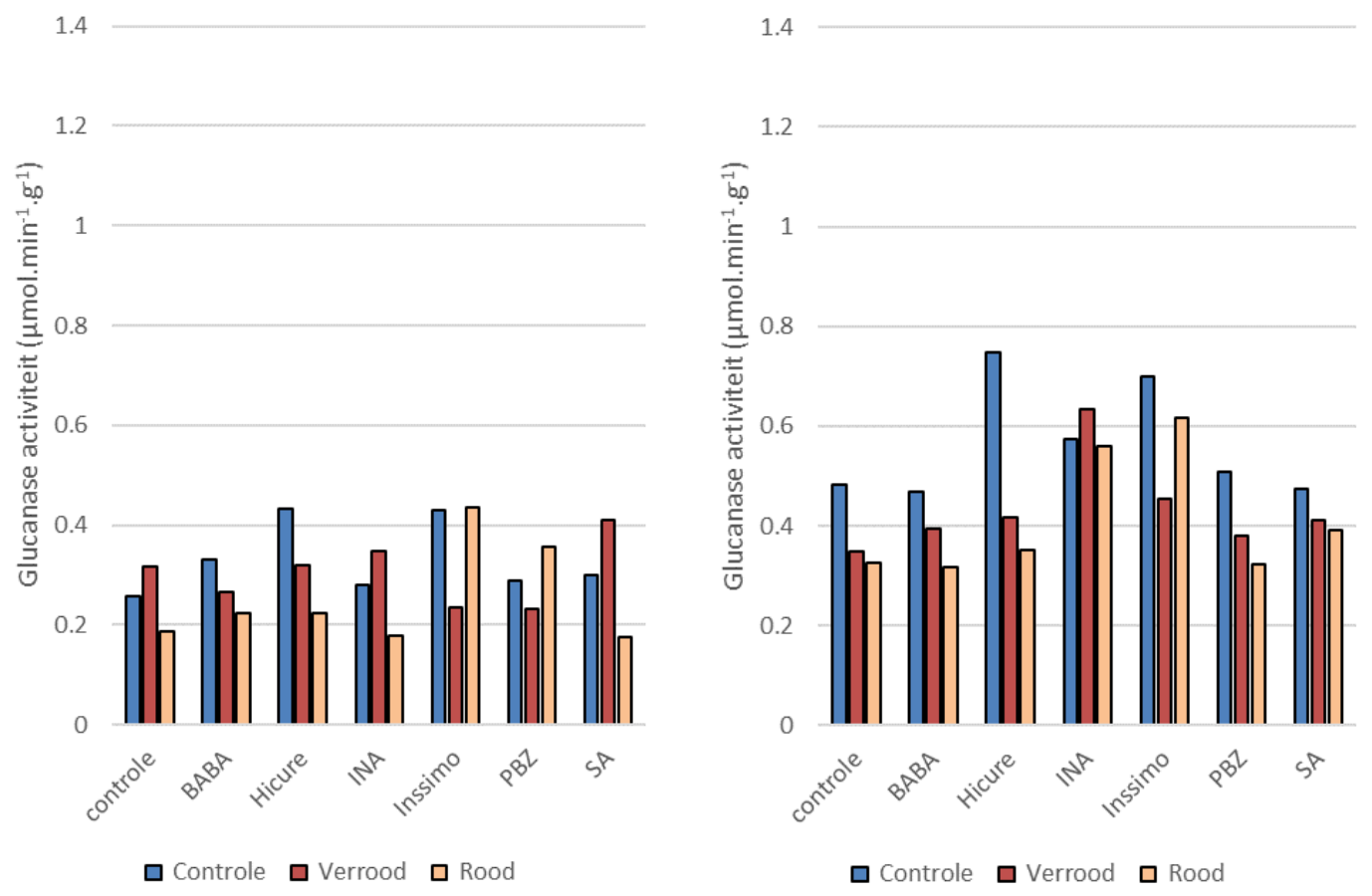

Figur 4.6 De $\beta$-1,3-glucanase activiteit in de verschillende groepen gerberaplanten bepaald vóór meeldauwinfectie $(T=0$; linkerfiguur; $L s d=0.209)$ en na meeldauwinfectie $(T=1$; rechterfiguur; $L s d=0.262) . n=3$.

In dit kasexperiment leidde eenmalige bladtoepassing van de elicitors INA en Inssimo gevolgd door inoculatie met echte meeldauw bij zowel tomaat als bij gerbera tot systemische expressie van de SAR-merker PR2 (gemeten in termen van glucanase-activiteit). Bij tomaat werd geen LED-effect waargenomen op de PR2-expressie; bij gerbera was de PR2-expressie gemiddeld het hoogste in de LED-controle-groepen. In absolute zin was de PR2-expressie met name bij gerbera betrekkelijk zwak. De analyses aan tomaat lieten echter geen of nagenoeg geen inductie van PR1 zien, en ook de relatief lage salicylzuurgehaltes correleerden niet met de PR2expressie die werd waargenomen met INA- en Inssimo-behandelingen. Kennelijk waren de condities voor inductie van een krachtige SAR-respons in dit experiment ongunstig. De resultaten wijzen op een potentieel sterkere werkzaamheid van INA en Inssimo voor de inductie van SAR dan de inducers PBZ, SA en BABA. Een mogelijke verklaring is dat INA en Inssimo in de signaal-transductieketen downstream van SA werkzaam zijn, en hun werking in theorie dus minder onderhevig zijn aan eventuele antagonistische factoren dan de werkzaamheid van PBZ en SA. De BABA-receptor is weliswaar downsteam van SA gelokaliseerd, maar BABA is mogelijk betrokken bij een aanzienlijk complexer netwerk van weerbaarheidsreacties (Luna et al, 2014; Ton et al, 2005).

\subsection{Periode en dur van de LED-behandelingen per etmaal; salicylzuur en jasmonzuur}

\subsubsection{Inleiding}

De controle van fytochroom-afhankelijke processen door toepassing van rood- en verroodstuurlicht lijkt onder praktijkomstandigheden lastig te verwezenlijken gedurende de dagperiode wegens de wisselende stralingsintensiteit van de zon en van eventuele bijbelichting. Om per etmaal een fytochroom gereguleerd effect van enige duur op systemic acquired resistance (SAR) te verkrijgen, ligt het voor de hand om de stuurlichtbehandeling in het begin van de 
donkerperiode te geven, of gedurende de dag maar deze dan tenminste tot in het begin van de donkerperiode door te laten lopen. In het hier gepresenteerde kasexperiment werd het effect van beide regimes op de geïnduceerde SAR-expressie van tomaat bestudeerd. De gebruikte elicitor was 2,6-dichloro isonicotinezuur (INA). In het verleden is in tomat een met SARexpressie gepaard gaande toename van het SAR-hormoon salicylzuur (SA) vastgesteld. Voor de regulatie van hormoonprocessen zijn doorgaans niet de absolute hormoonconcentraties bepalend, maar wel de balans van de verschillende relevante hormonen. De literatuur wijst op een antagonistische rol van met name jasmonzuur (JA) op de lokale regulerende SA-activiteit van SAR-genexpressie (Robert-Seilaniantz et al, 2011). Om behalve de respons op de absolute SA-gehaltes ook de respons op de verhouding van SA met JA te kunnen vast stellen, werd in de bladmonsters voor en na meeldauwinoculatie ook JA bepaald.

\subsubsection{Uitvoering van het experiment}

Het experiment vond plaats in november en december 2016 in een groot kascompartiment (144 $\mathrm{m}^{2}$ ) van Wageningen UR op locatie Bleiswijk. Op tien eb- en vloedtafels werden per tafel circa 3 weken oude tomatenplanten geplaatst die zich elk in afzonderlijke potten met potgrond bevonden (cv Komeett, vanuit zaad opgekweekt). Elke tafel onderging vanaf dat moment gedurende de dagperiode en/of het begin van de donkerperiode een rood $\left(5 \mu \mathrm{mol} . \mathrm{s}^{-1} \cdot \mathrm{m}^{-2}\right)$, verrood $\left(50 \mu \mathrm{mol} . \mathrm{s}^{-1} \cdot \mathrm{m}^{-2}\right)$ of geen stuurlichtbehandeling, die werden toegediend vanuit LEDmodules die zich 2 meter boven elke tafel bevonden. Aldus werden in 2-voud vijf LED-stuurlichtbehandelingen gecreëerd, namelijk (1) twee tafels zonder LED-stuurlicht ("Controle"), (2) twee tafels met $50 \mu \mathrm{mol} . \mathrm{s}^{-1} \cdot \mathrm{m}^{-2}$ verrood vanaf het begin van de dag tot vlak voor middernacht ("Verrood lang"), (3) twee tafels met $50 \mu \mathrm{mol} . \mathrm{s}^{-1} \cdot \mathrm{m}^{-2}$ verrood vanaf het begin van de avond tot vlak voor middernacht ("Verrood kort"), (4) twee tafels met $5 \mu \mathrm{mol} . \mathrm{s}^{-1} \cdot \mathrm{m}^{-2}$ rood vanaf het begin van de dag tot vlak voor middernacht ("Rood lang"), en (5) twee tafels met $5 \mu \mathrm{mol}^{-1} \mathrm{~s}^{-1} \mathrm{~m}^{-2}$ rood vanaf het begin van de avond tot vlak voor middernacht ("Rood kort"), zie figuur 4.7.

Daglicht werd op donkere dagen $\left(<200 \mu \mathrm{mol} . \mathrm{s}^{-1} \cdot \mathrm{m}^{-2}\right)$ aangevuld met 12 SON-T lampen (100 $\mu \mathrm{mol} . \mathrm{s}^{-1} \cdot \mathrm{m}^{-2}$; 7000-10000 lux van 7:00 tot 23: uur). Temperatuurinstellingen waren $20^{\circ} \mathrm{C}$ van 9:00-18:00 uur en $18^{\circ} \mathrm{C}$ van 18:00 -9:00 uur). RV was 70\%. Middels eb en vloed werd standaard nutriëntenvoeding voor tomaat toegediend en bevochtigd. Acht dagen na de start van de LED-belichting werden plantlengtemetingen verricht om vast te stellen of de planten daadwerkelijk een verschillende fytochroom-aansturing ervoeren van de verschillende LEDregimes. Toen dat het geval bleek te zijn, werden de planten een week later onder dezelfde LED-lichtregimes naar grotere potmaat overgebracht, en werd het temperatuurregime verlaagd naar $18^{\circ} \mathrm{C}$ (dag) en $16^{\circ} \mathrm{C}$ (nacht). Drie dagen daarna werden per tafel drie planten behandeld met 1 mM INA (bespuiting van de twee onderste samengestelde bladeren); drie onbehandelde planten per tafel fungeerden als controle-groep. Behandelde en onbehandelde planten stonden door elkaar. Drie dagen na toediening van de elicitors werden de planten 's middags geïnoculeerd met een vers bereide suspensie van meeldauwsporen (ca. $10^{4}$ conidia/ml), waarna de RV gedurende 24 uur op 90\% werd gehouden. De meeldauw-suspensies werden bereid uit het mycelium van door echte meeldauw aangetaste tomatenplanten en werden binnen circa 30 minuten na bereiding middels bespuiting op het gewas gebracht. In de ochtend van de dag van meeldauwinoculatie elke groep planten uniform bemonsterd ( $T=0$-bemonstering). Zes dagen later werd elke groep planten in de ochtend opnieuw uniform bemonsterd ( $T=1$-bemonstering). De mengmonsters werden onmiddellijk ingevroren in vloeibare stikstof en bewaard bij $-80^{\circ} \mathrm{C}$ tot aan de verwerking voor analyse van PR1, PR2, salicylzuur en jasmonzuur. Elf dagen na inoculatie waren op de planten meeldauwvlekjes zichtbaar. Elf dagen daarna, dus 22 dagen na inoculatie werd de meeldauwbladbedekking visueel beoordeeld. Op de dag van de laatste monstername $(T=1)$ werden aan 3 onbemonsterde, ongeeliciteerde tomatenplanten per tafel SPAD-metingen (Minolta SPAD 502 PlusChlorofyl Meter) en lengtemetingen verricht. 


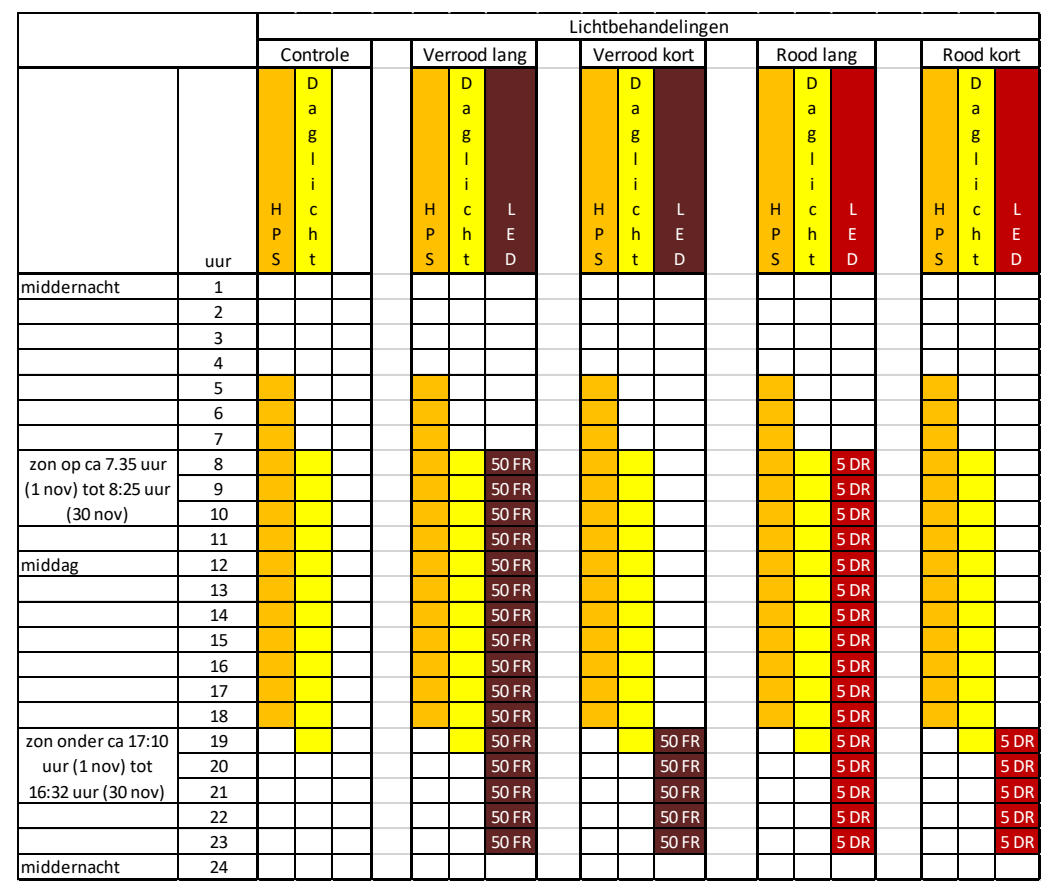

Figuur 4.7 De vijf LED-regimes. De controle-groepen ontvingen geen LED-belichting, de LED-behandelde groepen ontvingen per etmaal gedurende de dag en de avond, of uitsluitend in de avond verrod of rood stuurlicht. Alle groepen ontvingen normaal daglicht (novemberdecember) aangevuld met HPS-bijbelichting.

\subsubsection{Resultaten en conclusies}

Geheel volgens verwachting vertoonden de groepen planten die onder verrood stuurlicht stonden significant meer strekking dan de controlegroepen, die op hun beurt weer significant meer strekking vertoonden dan de groepen die onder rood stuurlicht opgroeiden (figuur 4.8). Hieruit kan geconcludeerd worden dat de voor het experiment benodigde LED-aansturing van fytochroom daadwerkelijk had plaats gevonden. Toediening van verrood licht vanaf de ochtend tot aan de nacht ('Verrood lang') leidde tot wat langere planten dan toediening uitsluitend in de avond gedurende de eerste uren van de donkerperiode ('Verrood kort'). Een dergelijk significant lengteverschil deed zich niet voor tussen 'Rood lang' en 'Rood kort'. Behandeling met elicitor leidt doorgaans tot enig opbrengstverlies die vaak meetbaar tot uitdrukking komt in een iets kortere plantlengte ('cost of tolerance), maar dat was hier, zes dagen na toediening van INA (nog) niet het geval (figuur 4.8).

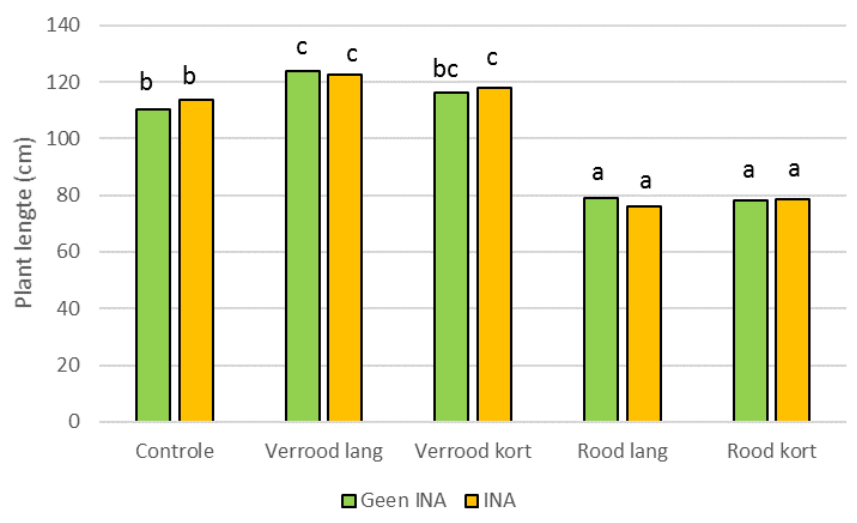

Figur 4.8 Gemiddelde plantlengte van de tomatenplanten behorend tot de verschillende behandelingsgroepen, gemeten zes dagen na INA-toediening en circa 8 weken na zaaien. Waarden met ongelijke letter zijn significant verschillend. 


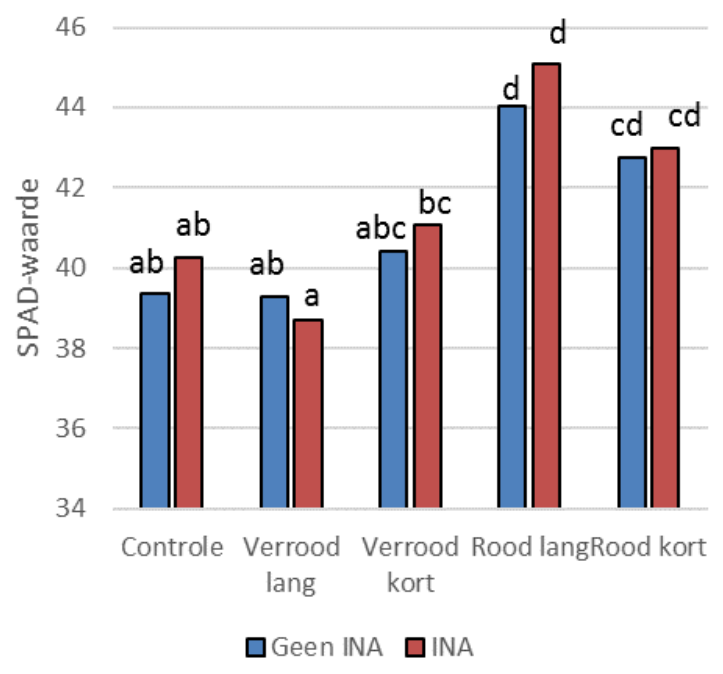

Figuur 4.9 Relatief chlorofylgehalte uitgedrukt in SPAD-waarden, gemeten zes dagen na INA-toediening en circa 8 weken na zaaien. Hogere SPAD-waarden geven hogere chlorofylgehalten weer. Waarden met ongelijke letter zijn significant verschillend.

De verschillende stuurlichtregimes brachten ook significante verschillen teweeg in het chlorofylgehalte (figuur 4.9). De planten belicht met rood stuurlicht vertoonden significant hogere chlorofylgehaltes dan de controlegroep en dan de groep die gedurende dag en avond verrood stuurlicht ontving ('Verrood lang').

Figuur 4.10 toont voor de verschillende behandelingsgroepen de PR2-expressie enkele uren voor $(T=0)$ en zes dagen na $(T=1)$ meeldauwinoculatie, gemeten in termen van glucanaseactiviteit. Zoals verwacht was de PR2-expressie na meeldauwinoculatie bij alle groepen toegenomen. Daarbij werden er significante effecten vastgesteld van zowel de elicitortoediening, als van de LED-behandelingen. Binnen elke LED-behandelingsgroep zorgde INA voor een significante toename van de glucanase-activiteit (figuur 4.10). Zowel in de niet geëliciteerde als in de geëliciteerde groepen die per etmaal lang onder rood stuurlicht stonden ('Rood lang') en kort onder rood stuurlicht stonden ('Rood kort') werd een significant hogere PR2-activiteit gevonden dan in de corresponderende LED-controle- en Verrood-groepen (figuur 4.10). Er werd geen interactie tussen elicitor en LED-behandeling gevonden. Kennelijk dragen beide behandelingen hier additief bij aan het inducerende effect op deze SAR-merker.

Figuur 4.11 toont de relatieve hoeveelheid van het gemeten PR1-RNA op T=1 (zes dagen na meeldauwinoculatie) ten opzichte van $\mathrm{T}=0$ (enkele uren vóór meeldauwinoculatie), waarbij genormaliseerd is ten opzichte van de expressie van het 'huishoudgen' L33 (figuur 4.11, grafiek links) en het 'huishoudgen' Ef1a (Figuur 4.11, grafiek rechts). Beide PR1-bepalingen laten een significant effect zien van de LED-behandelingen op de PR1-expressie. In tegenstelling tot de LED-controle-groepen en de groepen die van de ochtend tot in de avond aan verrood stuurlicht blootstonden ('Verrood lang'), vertoonden de beide groepen die onder de rode LEDs stonden ('Rood lang' en Rood kort') na meeldauwinoculatie een sterke en significante toename van PR1RNA (figuur 4.11). De groepen die slechts in de avonduren met verrood stuurlicht behandeld waren ('Verrood kort') vormden in dit beeld een opmerkelijk anomalie, omdat ook zij een sterke, significante verhoging van PR1 te zien gaven (figuur 4.11). Wanneer we uitgaan van een zuiver fytochroom gereguleerd proces, dan is deze waarneming in tegenspraak met de waarneming dat ook rood licht in de avond ('Rood kort') tot verhoogde expressie van PR1 leidde. Genormaliseerd met L33 gaf de PR1-expressie een significant elicitor-effect te zien (Figuur 4.11, grafiek links); genormaliseerd met Ef1a gaf de PR1-expressie geen significant INA-effect te zien, wat veroorzaakt werd door de Ef1a-uitbijter van de niet-geëliciteerde planten onder 'Rood lang' (Figuur 4.11, grafiek rechts). Niettemin kan geconcludeerd worden dat INA een groot inducerend effect had op de expressie van PR1. 


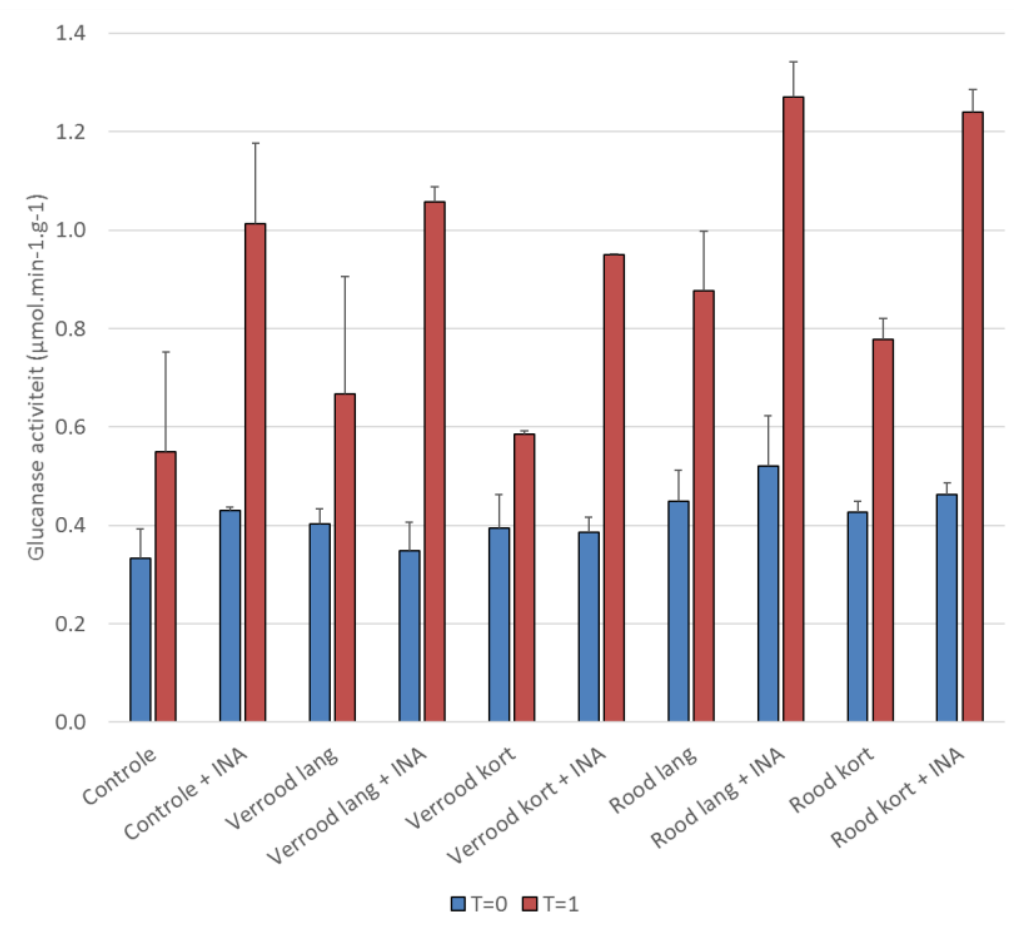

Figuur 4.10 PR2-expressie enkele uren voor $(T=0)$ en zes dagen na $(T=1)$ meeldauwinoculatie, gemeten in termen van glucanase-activiteit. Lsd=0.193; $n=2$.

L33

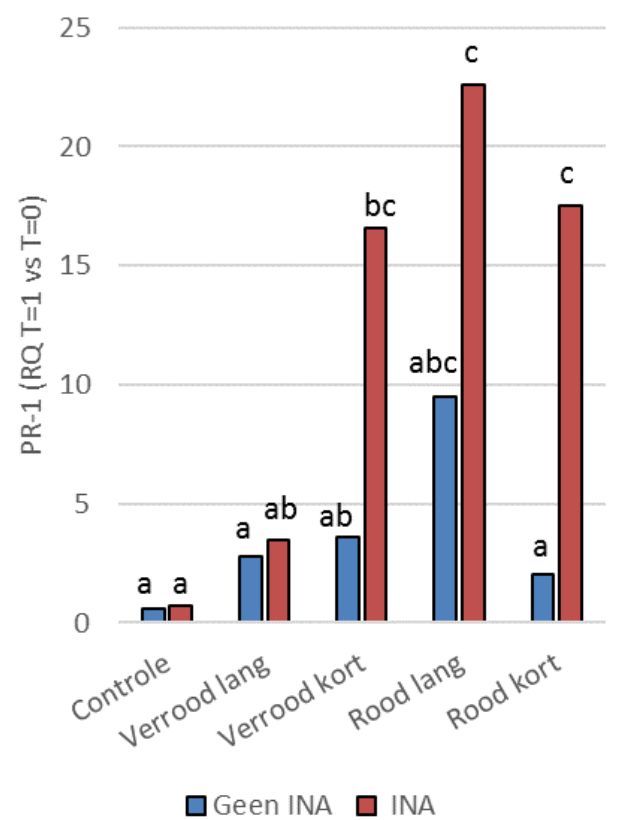

Ef1a

25

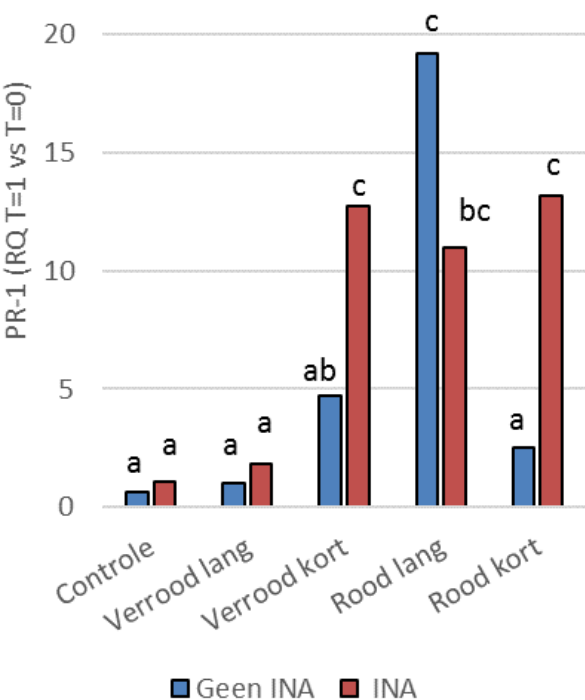

Figuur 4.11 De relatieve hoeveelheid PR1-expressie op tijdstip $T=1$ (zes dagen na meeldauwinoculatie) en $T=0$ (enkele uren vóór meeldauwinoculatie) bepaald t.o.v. huishoudgen L33 (grafiek links) en huishoudgen Ef1a (grafiek rechts). Waarden met ongelijke letter zijn significant verschillend. $n=2$.

Figuur 4.12 toont de in de bladmonsters gemeten gehaltes van het biologische actieve, vrije salicylzuur (SA), en figuur 4.13 toont de jasmonzuur (JA) gehaltes in dezelfde monsters. Met deze gegevens is berekend wat de JA/SA-gewichtsverhouding was (weergegeven in figuur 4.14). Opvallend is dat de SA-gehaltes van alle monsters in een relatief marginale range van 
slechts enkele nanogrammen per gram versgewicht lagen. Er werden geen significante effecten waargenomen van de elicitor-behandeling, van de LED-behandeling, en van het oogstmoment $(T=0$ vs $T=1)$. De JA-gehaltes bevonden zich in een bredere range van circa 10 tot $100 \mathrm{ng} / \mathrm{g}$ versgewicht (Figuur 4.13). Er werd een significant effect van de LED-belichting op het JAgehalte waargenomen, met de laagste JA-gehaltes bij de groepen die slechts in de avonduren stuurlicht ontvingen ('Verrood kort' en 'Rood kort') en de hoogste JA-gehaltes bij de groepen die zowel gedurende de dag als gedurende de avond stuurlicht ontvingen ('Verrood lang' en 'Rood kort'). Er werden geen significante effecten op JA-gehalte waargenomen van de elicitorbehandeling, en van het oogstmoment ( $T=0$ vs $T=1)$; er was geen significante interactie tussen licht en elicitor. Interessant is hoe de verhouding JA/SA veranderde tussen $\mathrm{T}=0$ (enkele uren voor meeldauwinoculatie) en $T=1$ (zes dagen na meeldauwinoculatie). Figuur 4.14 laat zien dat deze verhouding in nagenoeg alle gevallen toenam (significant effect). Er was geen significant effect van LED en elicitor op de JA/SA-verhouding.

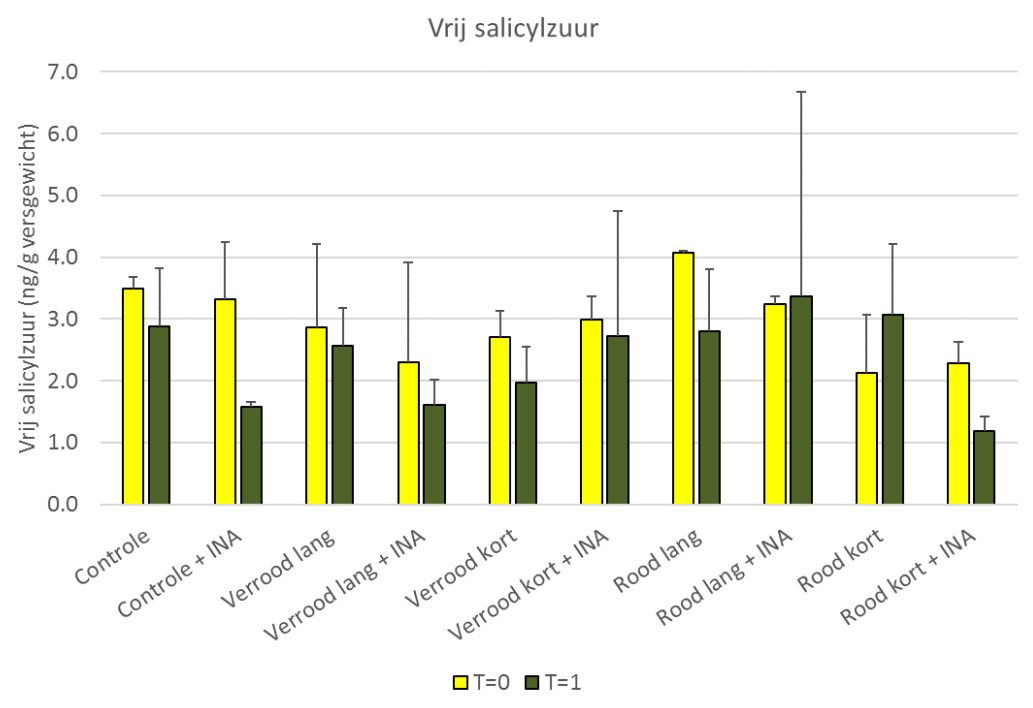

Figuur 4.12 Gehalte vrij salicylzuur enkele uren voor $(T=0)$ en zes dagen na $(T=1)$ meeldauwinoculatie, uitgedrukt in $n g$ per $g$ versgewicht bladmonster. $L s d=2.29 ; n=2$.

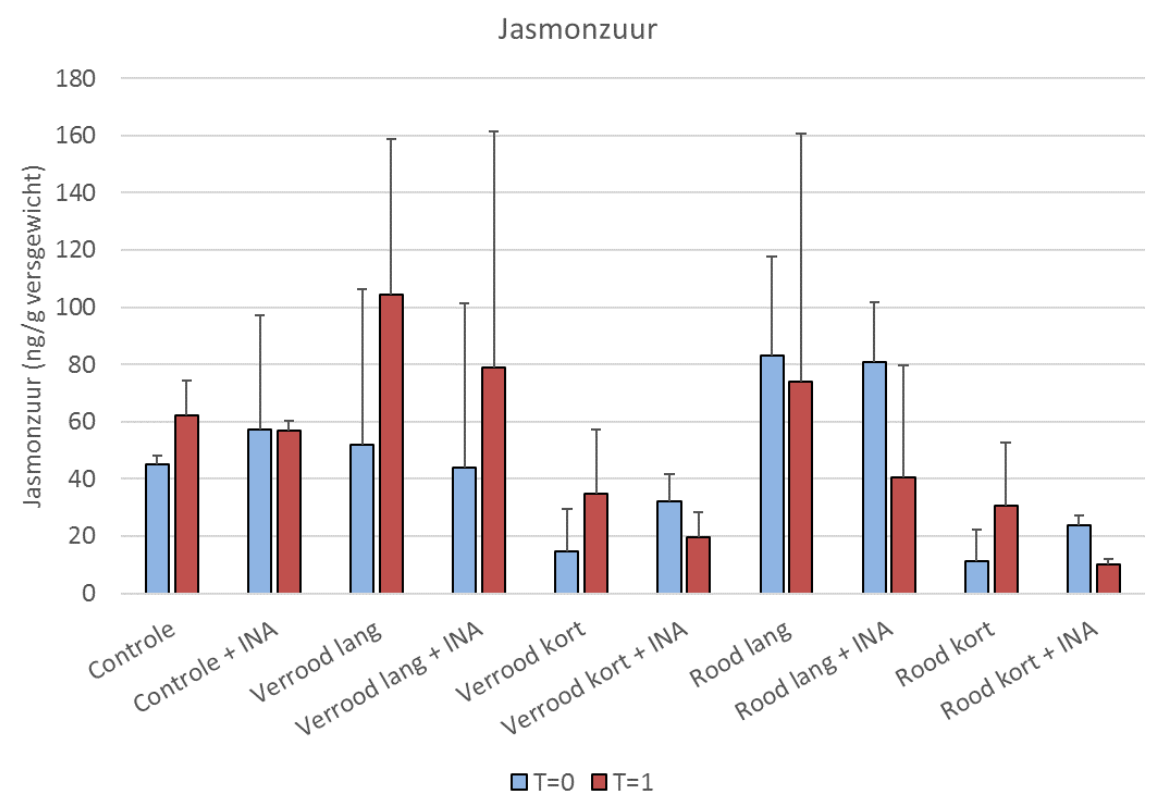

Figuur 4.13 Gehalte jasmonzuur enkele uren voor $(T=0)$ en zes dagen na $(T=1)$ meeldauwinoculatie, uitgedrukt in $n g$ per $g$ versgewicht bladmonster. $L s d=73.21 ; n=2$. 


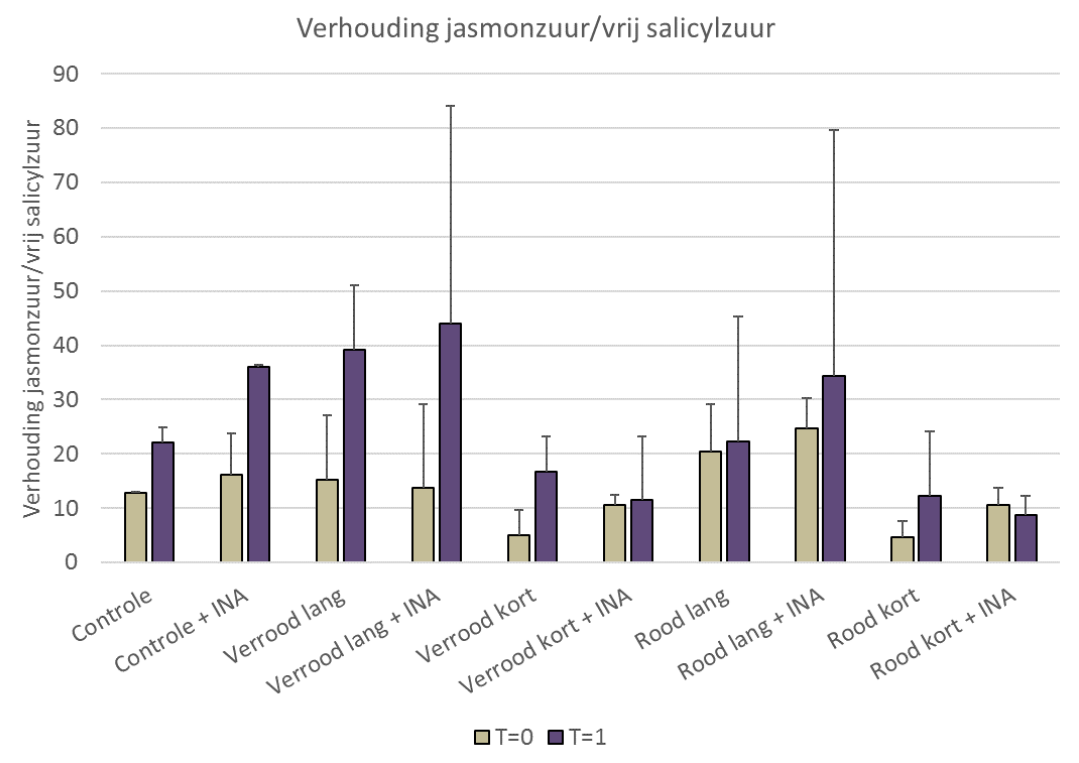

Figuur 4.14 Gewichtsverhouding jasmonzuur/salicylzuur enkele uren voor $(T=0)$ en zes dagen na $(T=1)$ meeldauwinoculatie. De molecuulmassa van JA is $210.27 \mathrm{~g} / \mathrm{mol}$ en die van $S A$ is $138.122 \mathrm{~g} / \mathrm{mol}$. Lsd=31.91; $n=2$.

Elf dagen na inoculatie waren in alle groepen duidelijke meeldauwvlekken op het gewas te zien. Figuur 4.15 toont voor de verschillende behandelingsgroepen de gemiddelde bladbedekking met meeldauwmycelium 22 dagen na inoculatie. Merk op dat deze meeldauwbedekking dus mede betrekking heeft op de tweede generatie meeldauw die uit de eerste meeldauwvlekken is voort gekomen. Op het moment van deze meeldauwscore waren de planten iets hoger dan 2 meter en daarmee enkele decimeters boven de LED-armaturen uitgegroeid. Alle LED-belichte groepen hadden een significant hogere meeldauwbedekking dan de controle-groepen, behalve de met INA behandelde planten die gedurende de dag en de avond rood stuurlicht ontvingen ('Rood lang'). In de meeste gevallen lag de gemiddelde meeldauwbedekking weliswaar lager bij de INA-behandelde groepen, maar dit effect was niet significant.

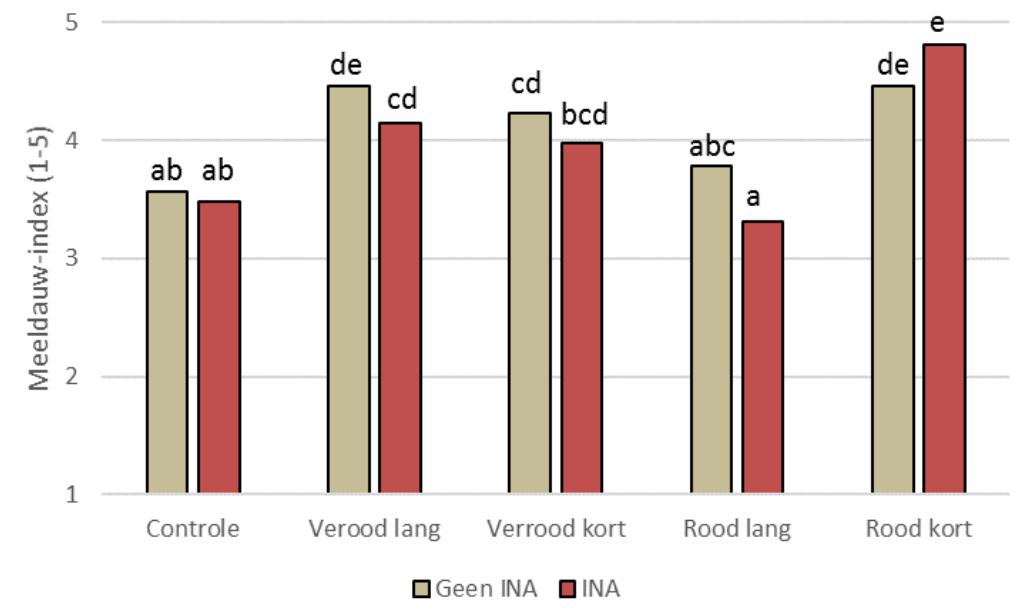

Figuur 4.15 Gemiddelde bladbedekking met meeldauwmycelium 22 dagen na inoculatie uitgedrukt in een meeldauwindex die loopt van 1 (geen meeldauwbedekking) tot 5 (volledige meeldauwbedekking van het blad). Lsd=0.6; $n=2$.

In dit kasexperiment is bij tomaat onderzocht of enkele uren stuurlicht (rood en verrood) toegediend vanaf het begin van de donkerperiode ('kort') tot andere SAR-expressie leidt dan een blootstelling vanaf de ochtend doorlopend tot enkele uren in de donkerperiode ('lang'). Voor de expressie van de SAR-merker PR2 (glucanase-activiteit) en PR1 onder rood stuurlicht werden 
geen verschillen vastgesteld. De belichtingsduur met stuurlicht had wel significante effecten op plantlengte en chlorofylgehalte, maar lastig te verklaren ook - uitsluitend onder verrood stuurlicht - op de expressie van PR1. Wat betreft de lichtkwaliteit: rood stuurlicht leidde tot significant hogere expressie van zowel PR1 en PR2 dan verrood stuurlicht.

Salicylzuur (SA) is lokaal (niet als systemisch signaalmolecuul) een essentiële regulerende factor voor de expresssie van SAR-genen. In dit experiment werd echter geen directe relatie tussen SA-gehalte en SAR-expressie waargenomen. Op zichzelf is dat niet opmerkelijk omdat het complexe regulatie-mechanismen betreft waarin de uiteindelijke balans van alle relevante regulerende factoren bepalend is. Daarom is in dit experiment ook onderzocht of de verhouding JA/SA aanknopingspunten biedt. JA is een sturend hormoon voor HIR, het weerbaarheidsmechanisme dat verondersteld wordt antagonistisch te werken op SAR. In dit experiment werd echter inductie van SAR waargenomen met een toename van de JA/SA-verhouding. Hoe dit verklaard moet worden is onduidelijk. Merk op dat de SA-gehaltes in alle behandelingsgroepen relatief laag waren.

Interessant is de waarneming dat alle LED-belichte groepen een significant hogere meeldauwbedekking hadden dan de controle-groepen, behalve de met INA behandelde planten die gedurende de dag en de avond rood stuurlicht ontvingen ('Rood lang'). Hoewel rood stuurlicht tot verhoogde inductie van SAR leidde, vertaalde dit zich dus niet in minder meeldauwschade, en in het geval van 'Rood kort' zelfs in meer meeldauwschade. Deze resultaten suggereren dat het rode stuurlicht niet slechts tot verhoogde SAR-expressie leidt, maar ook andere processen die relevant zijn voor de meeldauwontwikkeling beïnvloedt, en wel in gunstige zin, zodat er althans in het pathosysteem tomaat/echte meeldauw per saldo nauwelijks resultaat bereikt wordt met de stuurlichtbehandeling. Om deze hypothese te onderzoeken moet een proefopzet gekozen worden waarin deze processen (of procesfasen) van elkaar onderscheiden kunnen worden.

\subsection{Stuurlicht voor en na meeldauwinoculatie; invloed van PAR op SAR}

\subsubsection{Inleiding}

De hierboven beschreven resultaten suggereerden dat het rode stuurlicht niet slechts tot verhoogde SAR-expressie leidt (wat in beginsel meeldauw onderdrukt), maar tevens andere processen beïnvloedt die meeldauwontwikkeling juist bevorderen, wat dan per saldo nauwelijks of geen resultaat in ziektebeheersing oplevert. Om deze hypothese te onderzoeken is in dit kasexperiment voor een proefopzet gekozen waarin twee procesfasen van elkaar onderscheiden kunnen worden, namelijk de fase vóór meeldauwinoculatie en de fase na meeldauwinoculatie (zie figuur 4.16 voor een schematische weergave van de proefopzet). Dit werd praktisch verwezenlijkt door delen van de onder de verschillende stuurlichtregimes geteelde groepen planten de ochtend na meeldauwinoculatie systematisch over de verschillende stuurlichtbehandelingen te herverdelen.

Voor SAR-expressie is het hormoon salicylzuur (SA) essentieel, zo is aangetoond met mutanten waarvan de SA-biosynthese gemankeerd was (Delaney et al, 1994). De SA-niveaus die in de hierboven beschreven experimenten waargenomen waren variëerden allen binnen de nanogram-range per gram versgewicht, zowel met als zonder voorbehandeling met SAR-elicitor.

In een experiment dat in 2014 door Wageningen UR uitgevoerd was, werden in tomaat echter ook circa 100-voudig hogere SA-gehaltes waargenomen. Mogelijk kan dit verschil verklaard worden door verschil in fotosynthetisch actieve straling (PAR) en wellicht ook door verschil in bijbelichting: de hoge SA-gehaltes werden indertijd (2014) gevormd onder relatief hogere PARniveaus (ca $1000 \mu \mathrm{mol} . \mathrm{s}-1 . \mathrm{m}-2$ in 2014 versus ca $400 \mu \mathrm{mol} . \mathrm{s}-1 . \mathrm{m}-2$ in dit project) met in 2014 kortere periodes van bijbelichting dan in de hierboven beschreven experimenten. 
Literatuurgegevens laten een PAR-afhankelijke SA-productie zien, met 100-voudige verschillen in SA-gehalte (Zeier et al, 2004: in het donker géén SA-productie in Arabidopsis; Kurepin et al, 2010: basale SA-niveau correleerde positief met PAR in hypocotylen van zonnebloem, van $\mathrm{ng} / \mathrm{g}$ $\mathrm{FW}$ tot $\mu \mathrm{g} / \mathrm{g} \mathrm{FW}$ ). Dezelfde auteurs rapporteerden dat de biosynthese van het weerbaarheidshormoon jasmonzuur (JA) in tegenstelling tot SA negatief correleerde met toegediende PARhoeveelheid (negatieve correlatie met PAR na SAR-inductie): de JA-productie was in Arabidopsis na primaire infectie in het betreffende geïnfecteerde blad het hoogst in het donker en lager met toenemende PAR (Zeier et al, 2004). Wat betreft de timing van PAR-toediening voorafgaande, tijdens en na elicitatie en infectie biedt de literatuur summiere aanwijzingen. Zo bleek de aanwezigheid van licht (PAR) noodzakelijk te zijn tijdens primaire (incompatibele) infectie om weerbaarheid in systemisch Arabidopsis blad te verkrijgen; bij zeer hoge PAR leek niet SAR maar een ander weerbaarheidssysteem aangeschakeld te worden in systemisch Arabidopsis weefsel (Zeier et al, 2004).
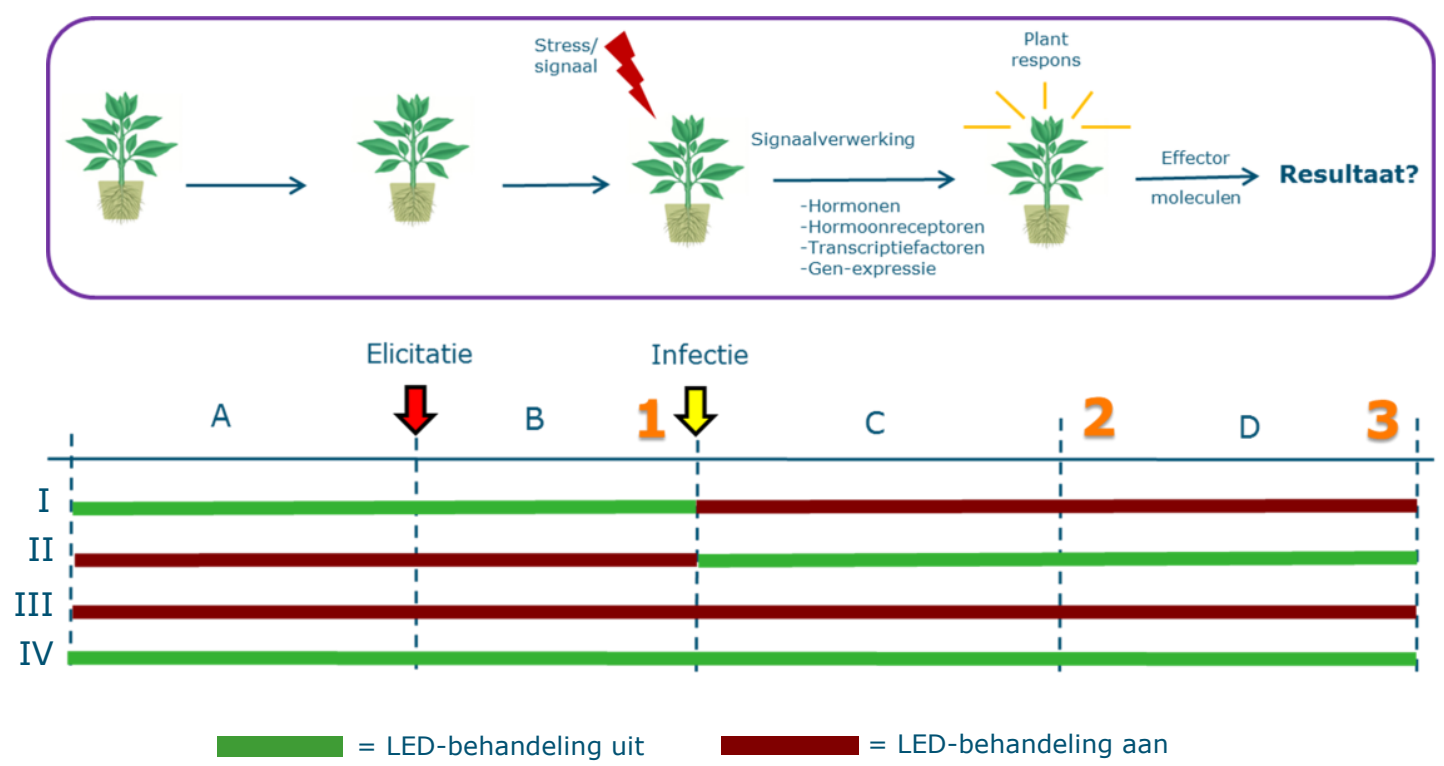

Figuur 4.16 Schematische voorstelling van de proefopzet. De planten ondergingen achtereenvolgens een fase $A$ waarin ze adapteren aan het toegediende $L E D$-stuurlicht, een fase $B$ warin ze reageren op elicitatie na toediening van de elicitor INA, een fase $C$ waarin ze in reactie op de meeldauwinoculatie een respons ontwikkelen waarmee ze zich in fase $D$ te weer stellen. Voor alle combinaties van rood en verrood stuurlicht zijn er vier varianten (I $t / m$ IV) waarbij de LED-behandelingen al dan niet aan of uit staan voor en na meeldauwinfectie, resulterend in 9 verschillende LED-behandelingen (zie figuur 4.20). Het experiment werd in 4voud uitgevoerd onder zowel $30 \%$ als $100 \%$ van het heersende daglicht.

De hierboven samengevatte waarnemingen gecombineerd met de geciteerde literatuur duiden op een mogelijke invloed van de PAR-kwantiteit op het potentieel SA te produceren en PReiwitten tot expressie te brengen. Om dit nader te onderzoeken werden in dit experiment twee praktijkrelevante (kwantitatieve) PAR-niveaus toegepast (maximaal zomerdaglichtniveau, en circa 30\% zomerdaglichtniveau, dit laatste te bewerkstelligen door toepassing van afschermdoek). In de voorgaande experimenten is gebruik gemaakt van (deels afgeschermd) daglicht aangevuld met kunstmatige PAR-bijbelichting. Om deze spectraal gecompliceerde omstandigheid te vermijden werd de proef uitgevoerd uitsluitend met daglicht.

Aldus bestond de proef uit 9 verschillende LED-behandelingen, onder hoog en laag PAR-niveau, met en zonder elicitatie met INA (totaal 36 behandelingen). De proef werd in 4-voud uitgevoerd 


\subsubsection{Uitvoering van het experiment}

Het experiment vond plaats in juli en augustus 2017 in een groot kascompartiment $\left(144 \mathrm{~m}^{2}\right)$ van Wageningen UR op locatie Bleiswijk. Het experiment omvatte in totaal 12 roltafels met elk 10 rijen van zes planten. De tafels waren random voorzien van LED-modules op $2 \mathrm{~m}$ hoogte boven de tafels, en van elkaar gescheiden door lichtdichte schermen. Het experiment was opgezet in 4 blokken van drie tafels, waarvan steeds 1 tafel was voorzien van rode LEDmodules ( $5 \mu \mathrm{mol} . \mathrm{m}^{-2} . \mathrm{s}^{-1}$ op $30 \mathrm{~cm}$ boven de tafel), 1 tafel was voorzien van verrode LEDmodules $\left(50 \mu \mathrm{mol} . \mathrm{m}^{-2} . \mathrm{s}^{-1}\right.$ op $30 \mathrm{~cm}$ boven de tafel), en 1 tafel was voorzien van dummiearmaturen die geen licht afgaven (controle-groepen). De LED-modules waren aangeschakeld van 7:00 tot 24:00 uur. Verder ontvingen de planten uitsluitend zomers daglicht zonder PARbijbelichting. Het kascompartiment zelf werd niet afgeschermd. Per tafel werden twee PARbelichtings-niveaus toegepast, namelijk (a) 100\% daglicht, en (b) 30\% daglicht (zie figuur 4.17). Dit werd bewerkstelligd door 30\%-lichtdoorlatend afschermdoek aan te brengen boven de noordelijke helft van elke tafel. Het doek (Harmony 6920 OFR, 100\% polyester, Svensson) werd aangebracht op de LED-armaturen, zodat de afgeschermde en de niet-afgeschermde tafelhelften gelijke hoeveelheden LED-belichting ontvingen. Metingen wezen uit dat het doek slechts de gewenste kwantitatieve, geen kwalitatieve wijzigingen van het zonlicht aanbracht. De tafelindeling van de diverse LED-behandelingen zijn weergegeven in figuur 4.18.

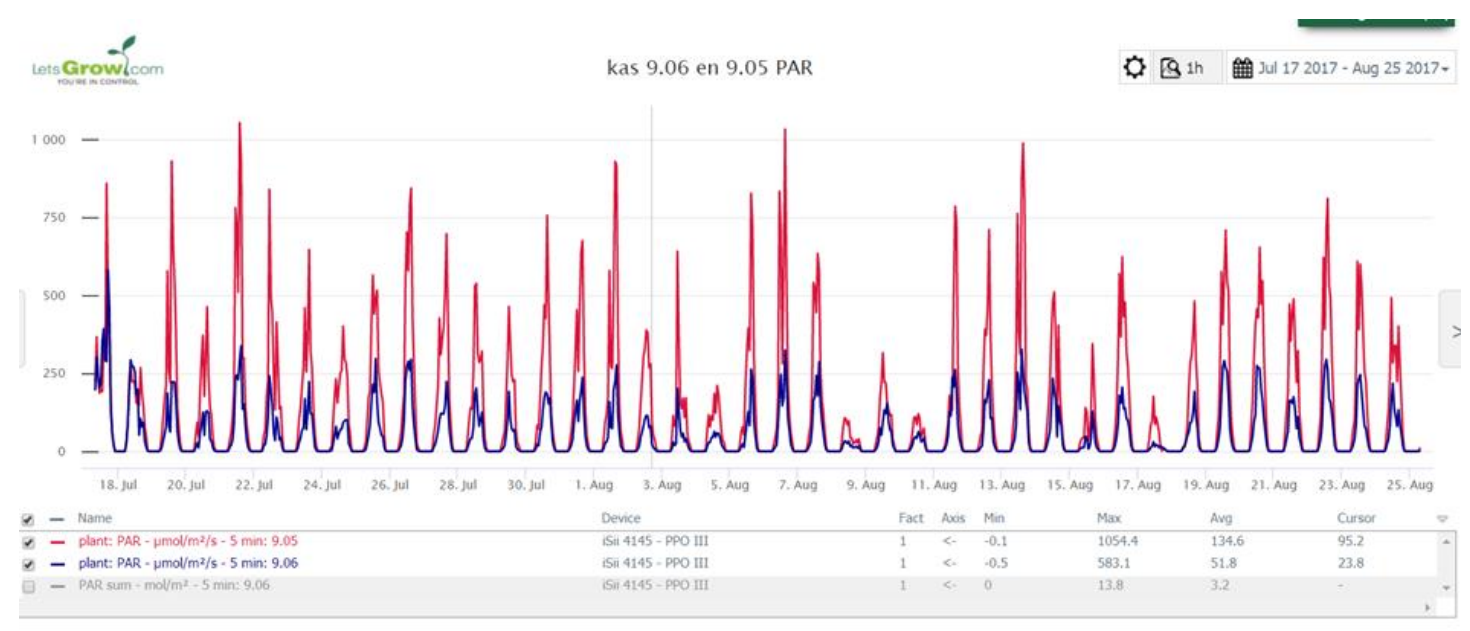

Figuur 4.17 PAR-niveaus tijdens het experiment gemeten op ca $50 \mathrm{~cm}$ boven de tafel onder het 30\%-lichtdoorlatend afschermdoek (30\% PAR; blauwe lijn) en onafgeschermd (100\% PAR; rode lijn).

Het plantmateriaal was tomaat (cv Komeett, bij de start circa 3 weken oud vanaf zaaidatum). Per tafel stonden 60 planten, individueel opgepot in potgrond. Hiervan werden steeds twee groepen (30\% PAR en 100\% PAR) van elk 12 planten (24 per tafel) bemonsterd; de overige planten fungeerden als randrij. Deze te bemonsteren planten waren voorzien van labels met nummering ( $1 \mathrm{t} / \mathrm{m} \mathrm{288)}$, zodanig dat hun posities op de tafels te herleiden waren. De planten die met elicitor (INA) behandeld werden, waren aan de kleur van hun labels te onderscheiden van de overige planten. De planten ontvingen standaardvoedingsoplossing middels eb- en vloedgift. Temperatuurinstellingen waren $20^{\circ} \mathrm{C}$ van 9:00-18:00 uur en $18^{\circ} \mathrm{C}$ van 18:00 -9:00 uur). Het kascompartiment werd gekoeld door opening van de dakramen. RV was $70 \%$.

De proef werd gestart door de circa 3 weken oude planten onder de verschillende lichtregimes op de roltafels te plaatsen. Na 3 weken werden 's ochtends de helft van elke planten-groep met elicitor behandeld (onderste twee echte bladeren bespoten met $1 \mathrm{mM}$ INA). Aldus waren er voorafgaande aan de meeldauwinoculatie voor elk LED-regime per tafel 4 groepen van 6 planten te onderscheiden, dus in totaal 12 verschillende groepen (zie figuur 4.19). 


\section{Noordzijde}

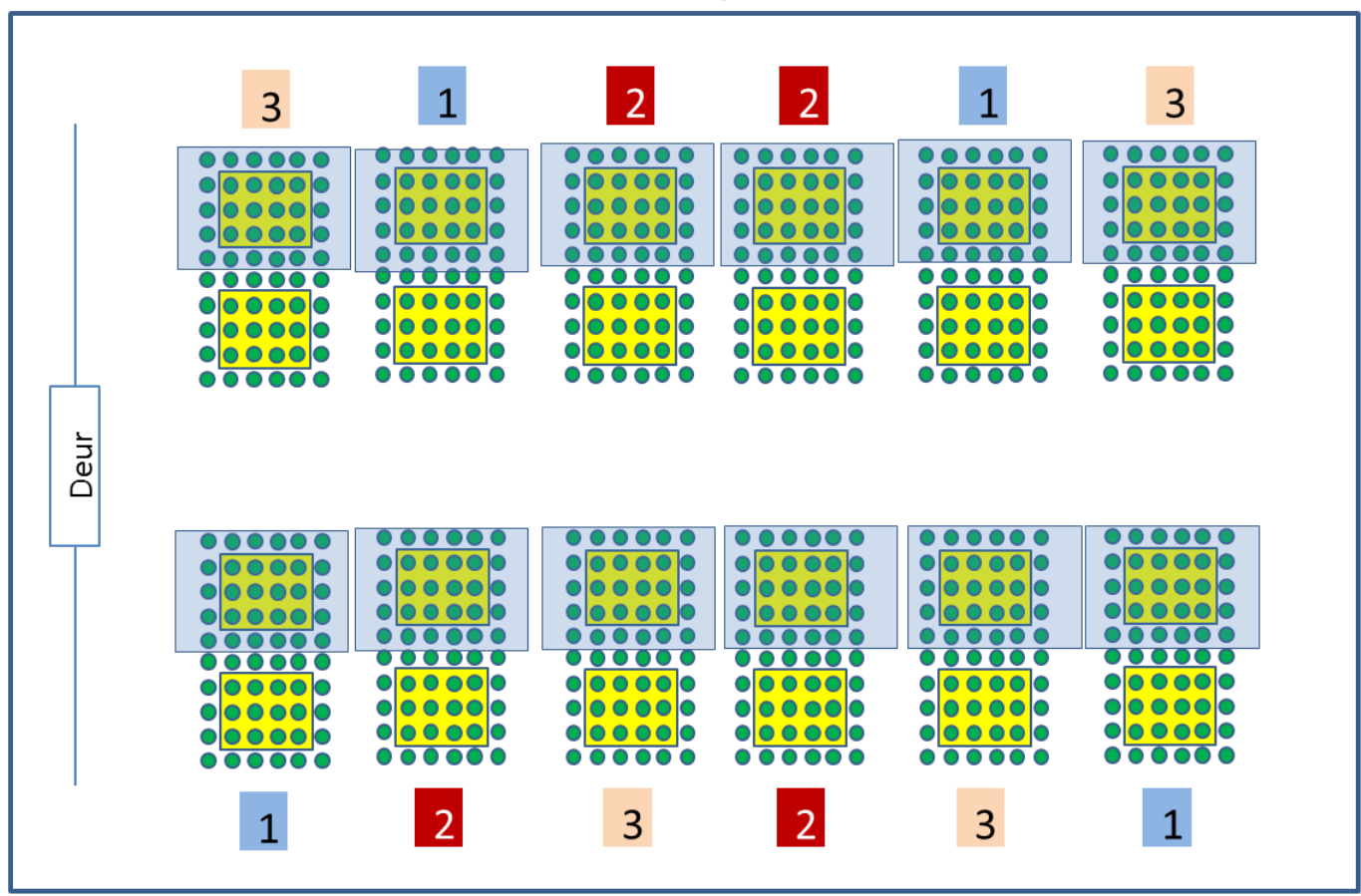

\section{Zuidzijde}

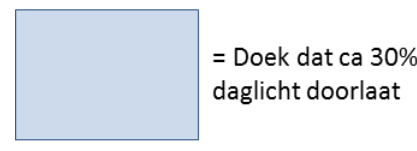
1 = Controle
2 = Verrode Led-belichting
3 = Rode Led-belichting

De te bestuderen planten (de overige zijn 'randrijen')

Figuur 4.18 Kasinrichting met twaalf roltafels, elk voorzien van LED-armaturen (of dummies voor de controle-groepen) en van elkaar gescheiden met lichtdichte schermen. Op elke tafel stonden 6 rijen van 10 planten in individuele potten op potaarde (aangeduid met de groene stippen). De noordzijde van elke tafel was afgeschermd met doek dat $30 \%$ van het daglicht tegenhield.

\begin{tabular}{|c|c|c|c|c|}
\hline Plantgroep & Led-regime & Licht-niveau (daglicht) & INA? & \# planten \\
\hline$A$ & (Controle) geen stuurlicht & $100 \%$ & $\mathrm{Ja}$ & 6 \\
\hline B & (Controle) geen stuurlicht & $100 \%$ & Neen & 6 \\
\hline c & (Controle) geen stuurlicht & $30 \%$ & $\mathrm{Ja}$ & 6 \\
\hline \multirow[t]{2}{*}{$\mathrm{D}$} & (Controle) geen stuurlicht & $30 \%$ & Neen & 6 \\
\hline & \multicolumn{2}{|c|}{ Aantal planten per tafel (excl. randrijen): } & & 24 \\
\hline $\mathrm{E}$ & Verrood & $100 \%$ & $\mathrm{Ja}$ & 6 \\
\hline $\mathrm{F}$ & Verrood & $100 \%$ & Neen & 6 \\
\hline G & Verrood & $30 \%$ & Ja & 6 \\
\hline \multirow[t]{2}{*}{$\mathrm{H}$} & Verrood & $30 \%$ & Neen & 6 \\
\hline & \multicolumn{2}{|c|}{ Aantal planten per tafel (excl. randrijen): } & & 24 \\
\hline 1 & Rood & $100 \%$ & $\mathrm{Ja}$ & 6 \\
\hline j & Rood & $100 \%$ & Neen & 6 \\
\hline K & Rood & $30 \%$ & Ja & 6 \\
\hline \multirow[t]{2}{*}{$\mathrm{L}$} & Rood & $30 \%$ & Neen & 6 \\
\hline & \multicolumn{2}{|c|}{ Aantal planten per tafel (excl. randrijen): } & & 24 \\
\hline
\end{tabular}

Figuur 4.19 Voorafgaande aan de meeldauwinfectie waren in 4-voud bovenstaande 12 plantgroepen te onderscheiden. 


\begin{tabular}{|c|c|c|c|c|c|c|}
\hline Behandeling & \multicolumn{2}{|c|}{ Fase } & & & Aantal planten per tafel & Tafel \\
\hline No. & \multicolumn{2}{|c|}{ Na inoculatie } & Licht-niveau (daglicht) & INA? & (excl. randrijen) & (Led) \\
\hline 1 & geen stuurlicht & geen stuurlicht & $100 \%$ & $\mathrm{Ja}$ & 2 & \\
\hline 2 & geen stuurlicht & geen stuurlicht & $100 \%$ & Neen & 2 & \\
\hline 3 & geen stuurlicht & geen stuurlicht & $30 \%$ & Ja & 2 & \\
\hline 4 & geen stuurlicht & geen stuurlicht & $30 \%$ & Neen & 2 & \\
\hline 5 & Verrood & geen stuurlicht & $100 \%$ & Ja & 2 & \\
\hline 6 & Verrood & geen stuurlicht & $100 \%$ & Neen & 2 & \\
\hline 7 & Verrood & geen stuurlicht & $30 \%$ & $\mathrm{Ja}$ & 2 & Controle \\
\hline 8 & Verrood & geen stuurlicht & $30 \%$ & Neen & 2 & \\
\hline 9 & Rood & geen stuurlicht & $100 \%$ & $\mathrm{Ja}$ & 2 & \\
\hline 10 & Rood & geen stuurlicht & $100 \%$ & Neen & 2 & \\
\hline 11 & Rood & geen stuurlicht & $30 \%$ & $\mathrm{Ja}$ & 2 & \\
\hline \multirow[t]{2}{*}{12} & Rood & geen stuurlicht & $30 \%$ & Neen & 2 & \\
\hline & & & & & 24 & \\
\hline & & & & , & & \multirow{13}{*}{ Verrood } \\
\hline$\frac{13}{14}$ & Verrood & Verrood & $\frac{100 \%}{100 \%}$ & Ja & $\frac{2}{2}$ & \\
\hline$\frac{14}{15}$ & Verrood & Verrood & $\frac{100 \%}{30 \%}$ & $\frac{\text { Neen }}{\text { Ja }}$ & 2 & \\
\hline 15 & Verrood & Verrood & $30 \%$ & $\mathrm{Ja}$ & 2 & \\
\hline 16 & Verrood & Verrood & $30 \%$ & Neen & 2 & \\
\hline 17 & geen stuurlicht & Verrood & $100 \%$ & $\mathrm{Ja}$ & 2 & \\
\hline 18 & geen stuurlicht & Verrood & $100 \%$ & Neen & 2 & \\
\hline 19 & geen stuurlicht & Verrood & $30 \%$ & $\mathrm{Ja}$ & 2 & \\
\hline 20 & geen stuurlicht & Verrood & $30 \%$ & Neen & 2 & \\
\hline 21 & Rood & Verrood & $100 \%$ & $\mathrm{Ja}$ & 2 & \\
\hline 22 & Rood & Verrood & $100 \%$ & Neen & 2 & \\
\hline 23 & Rood & Verrood & $30 \%$ & $\mathrm{Ja}$ & 2 & \\
\hline \multirow[t]{2}{*}{24} & Rood & Verrood & $30 \%$ & Neen & 2 & \\
\hline & & & & & 24 & \\
\hline & & & & & & \\
\hline 25 & Rood & Rood & $100 \%$ & $\mathrm{Ja}$ & 2 & \multirow{12}{*}{ Rood } \\
\hline 26 & Rood & Rood & $100 \%$ & Neen & 2 & \\
\hline 27 & Rood & Rood & $30 \%$ & $\mathrm{Ja}$ & 2 & \\
\hline 28 & Rood & Rood & $30 \%$ & Neen & 2 & \\
\hline 29 & geen stuurlicht & Rood & $100 \%$ & $\mathrm{Ja}$ & 2 & \\
\hline 30 & geen stuurlicht & Rood & $100 \%$ & Neen & 2 & \\
\hline 31 & geen stuurlicht & Rood & $30 \%$ & Ja & 2 & \\
\hline 32 & geen stuurlicht & Rood & $30 \%$ & Neen & 2 & \\
\hline 33 & Verrood & Rood & $100 \%$ & $\mathrm{Ja}$ & 2 & \\
\hline 34 & Verrood & Rood & $100 \%$ & Neen & 2 & \\
\hline 35 & Verrood & Rood & $30 \%$ & $\mathrm{Ja}$ & 2 & \\
\hline 36 & Verrood & Rood & $30 \%$ & Neen & 2 & \\
\hline
\end{tabular}

Figuur 4.20 Na de meeldauwinfectie waren in 4-voud bovenstaande 36 plantgroepen te onderscheiden.

Drie dagen na INA-bespuiting werden in de ochtend $(T=0)$ van elke plantgroep uniforme mengmonsters genomen aan het uiteinde van het bovenste volledig gestrekte samengestelde blad en onmiddellijk in vloeibare stikstof ingevroren en bij $-80^{\circ} \mathrm{C}$ bewaard voor monsteranalyse (in totaal 48 monsters op $\mathrm{T}=0$ ). In de middag van $\mathrm{T}=0$ (dus na bemonstering) werden de planten met meeldauw geïnoculeerd (homogene bespuiting van het gewas met $10^{4}$ conidia per $\mathrm{ml}$ suspensie, vers bereid uit met echte meeldauw aangetaste tomatenplanten). De ochtend na meeldauw-inoculatie werden per afzonderlijk blok en binnen beide PAR-groepen drie via loting bepaalde setjes van twee planten die met INA waren behandeld en drie via loting bepaalde setjes van twee planten die niet met INA waren behandeld van tafel (dus van LED-regime) verwisseld. Een week na meeldauwinoculatie werd 's ochtends $(T=1)$ een nieuwe bemonstering uitgevoerd. Het ging hier om 12 bladmonsters per tafel, elk samengesteld uit blaadjes van 2 planten. Bemonsteringswijze als bovenbeschreven. Door de uitwisselingsactie was het aantal van elkaar te onderscheiden behandelingen toegenomen naar 36 stuks zoals aangegeven in figuur 4.20. Omdat de proef in 4-voud uitgevoerd werd, kwam het totaal op $T=1$ te nemen monsters op 144 stuks. Circa 11 -14 dagen na meeldauwinoculatie werd bij alle planten individueel (288 stuks) de meeldauwaantasting op het tweede, derde en vierde blad-etage (geteld vanaf de cotylen) bepaald door telling van het aantal meeldauwvlekjes per samengesteld blad. Tevens werden plantlengtes en versgewicht van de bovengrondse delen bepaald, en werden chlorofyl gehaltes gemeten (SPAD-metingen; Minolta SPAD 502 PlusChlorofyl Meter). In de randrijen werden in 4-voud de bladoppervlaktes van het tweede derde en vierde samengestelde blad (vanaf de cotylen) bepaald. De bladmonsters werden geanalyseerd op expressie van PR-1, PR-2, en SA. 


\subsubsection{Resultaten en conclusies}

De verschillende LED- en PAR-behandelingen vertoonden significante effecten op de strekking en de biomassa van de tomatenplanten. Figuur 4.21 geeft een indruk van de verschillen in plantlengte en plantvolume voorafgaande aan de behandeling met elicitor (INA). Figuren 26 en 27 tonen de plantlengtes en bovengrondse versgewichten na afloop van het experiment. Vanzelfsprekend leidde 70\% PAR-reductie tot een dramatisch verminderde biomassa. Behandeling met INA had een significant reducerend effect op zowel plantlengte als biomassa figuur 4.22 en 4.23). Uit deze fysiologische responsen kan veilig geconcludeerd worden dat de planten zowel de PAR-, de LED- en de INA-behandelingen daadwerkelijk ervaren hebben.

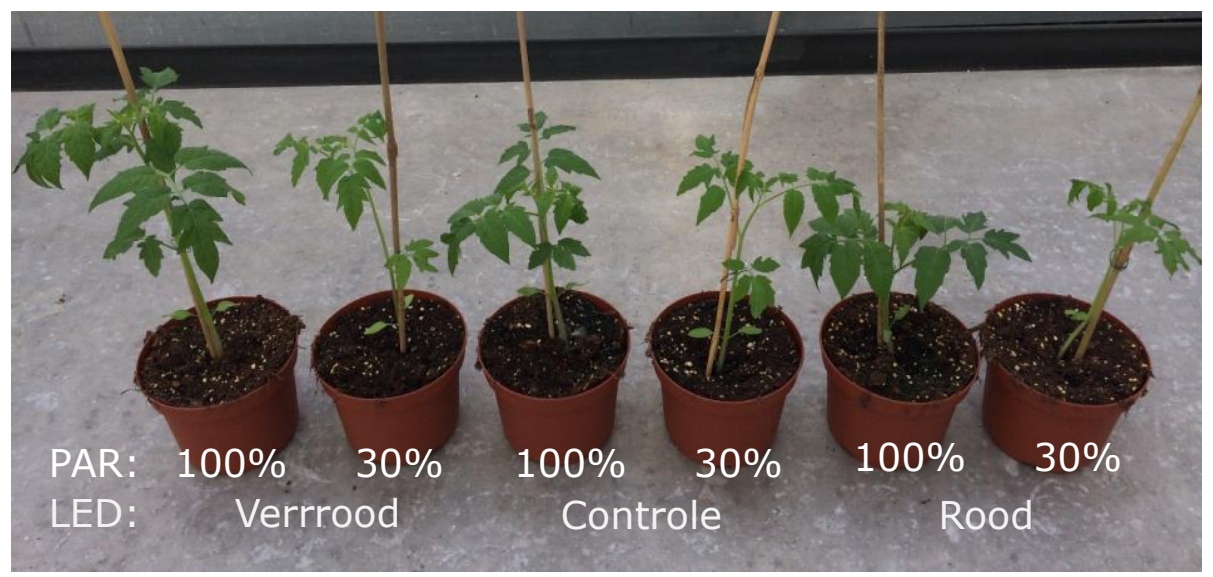

Figuur 4.21 Effect van de LED-behandelingen onder $30 \%$ en $100 \%$ PAR.

\begin{tabular}{rl|c|c|c|c|c|c|c|c|} 
Na inoculatie: & Geen LED & Verrood & Rood & Geen LED & Verrood & Rood & Geen LED & Verrood & Rood \\
Vóór inoculatie: & \multicolumn{3}{c|}{ Geen LED } & \multicolumn{3}{c|}{ Verrood } & \multicolumn{3}{c|}{ Rood } \\
\hline
\end{tabular}

160

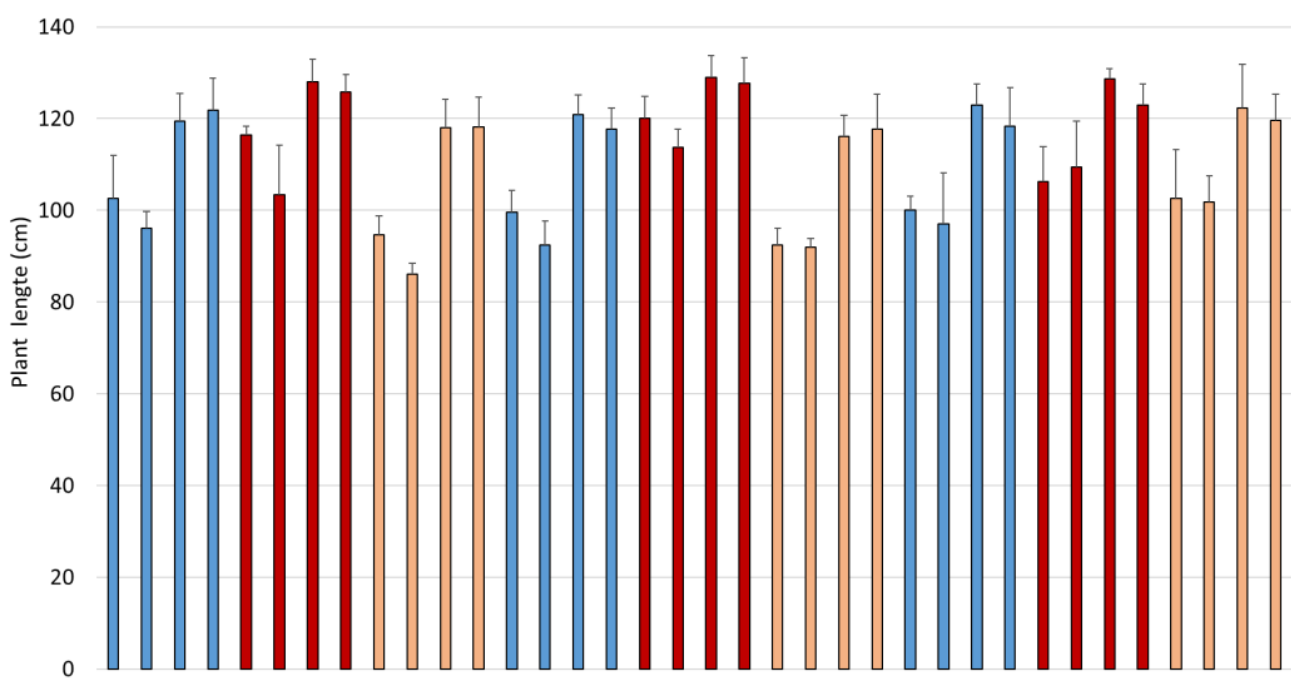

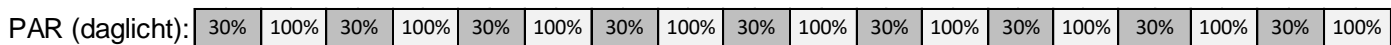

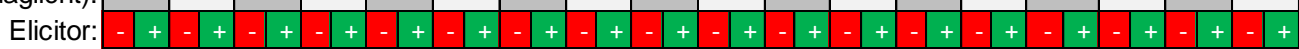

Figuur 4.22 Gemiddelde plantlengte van de 36 verschillende behandelingsgroepen na afloop van het experiment. De bij elke kolom behorende combinatie van 4 behandelingen is af te lezen boven de grafiek (LED-regime voor en na meeldauwinoculatie) en onder de grafiek (PARhoeveelheid en geen INA (rood '-')/wel INA (groen '+')). 


\begin{tabular}{rl|c|c|c|c|c|c|c|c|} 
Na inoculatie: & Geen LED & Verrood & Rood & Geen LED & Verrood & Rood & Geen LED & Verrood & Rood \\
\hline Vóór inoculatie: & \multicolumn{3}{c|}{ Geen LED } & \multicolumn{5}{c|}{ Verrood } \\
\cline { 2 - 5 }
\end{tabular}

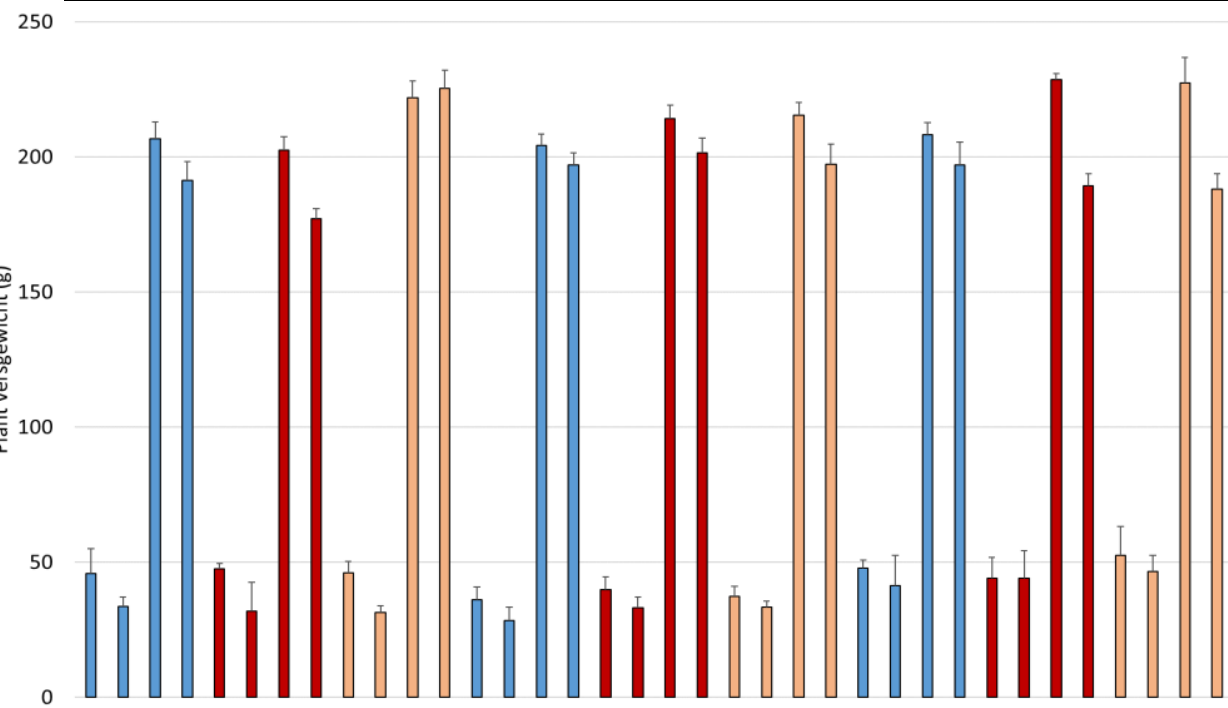

\begin{tabular}{|c|c|c|c|c|c|c|c|c|c|c|c|c|c|c|c|c|c|c|} 
PAR (daglicht): & $30 \%$ & $100 \%$ & $30 \%$ & $100 \%$ & $30 \%$ & $100 \%$ & $30 \%$ & $100 \%$ & $30 \%$ & $100 \%$ & $30 \%$ & $100 \%$ & $30 \%$ & $100 \%$ & $30 \%$ & $100 \%$ & $30 \%$ & $100 \%$ \\
\hline
\end{tabular} Elicitor:

Figuur 4.23 Gemiddeld bovengronds plantgewicht van de 36 verschillende behandelingsgroepen na afloop van het experiment. De bij elke kolom behorende combinatie van 4 behandelingen is af te lezen boven de grafiek (LED-regime voor en na meeldauwinoculatie) en onder de grafiek (PAR-hoeveelheid en geen INA (rood '-')/wel INA (groen '+')).

\begin{tabular}{|c|c|c|c|c|c|c|c|c|c|}
\hline \multirow{2}{*}{$\begin{array}{l}\text { Na inoculatie: } \\
\text { Vóór inoculatie: }\end{array}$} & Geen LED & Verrood & Rood & Geen LED & Verrood & Rood & Geen LED & Verrood & Rood \\
\hline & & Geen LED & & & Verrood & & \multicolumn{3}{|c|}{ Rood } \\
\hline
\end{tabular}

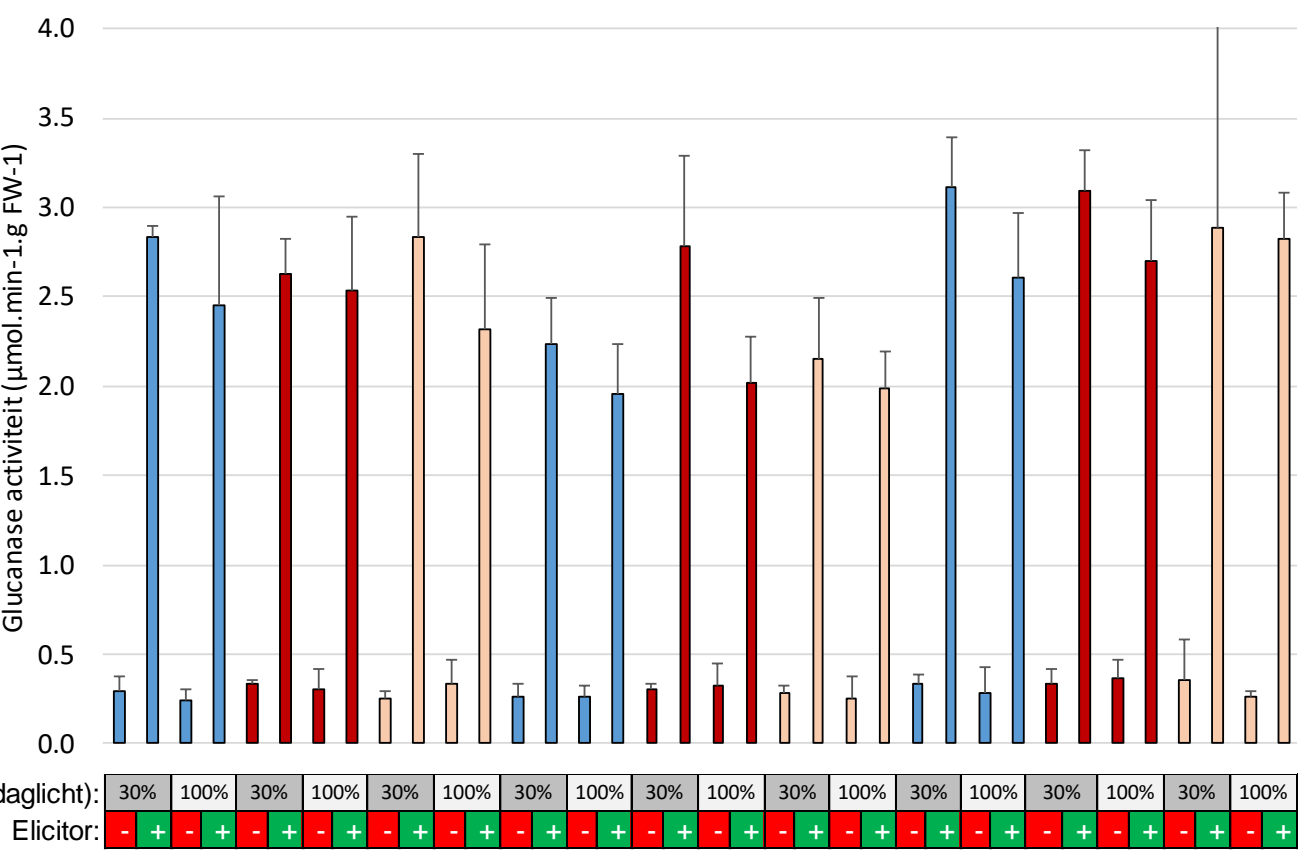

Figuur 4.24 Gemiddelde PR2-expressie geïnduceerd door de 36 verschillende behandelingscombinaties een week na meeldauwinoculatie $(T=1)$, gemeten in termen van glucanaseactiviteit. De bij elke kolom behorende combinatie van 4 behandelingen is af te lezen boven de grafiek (LED-regime voor en na meeldauwinoculatie) en onder de grafiek (PAR-hoeveelheid en geen INA (rood '-')/wel INA (groen ' + ')). Lsd=0.405; $n=4$.

De glucanase-activiteit (PR2) direct voorafgaande aan het moment van meeldauwinoculatie $(T=0)$ lag bij alle 36 behandelingsgroepen op het basisniveau van ongeveer $0.4 \mu \mathrm{mol} \cdot \mathrm{min}^{-1} \cdot \mathrm{g}^{-1}$. Figuur 4.24 toont de glucanase-activiteit (PR2) een week na meeldauwinoculatie $(T=1)$. De sterkste bijdrage aan de PR2-inductie werd geleverd door de behandeling met INA. Daarnaast 
was er een significant effect van PAR en een significante interactie tussen PAR en INAbehandeling: bij het lage PAR-niveau (30\% PAR) was de PR2-inductie van INA in alle groepen iets sterker dan bij het hoge PAR-niveau (100\% PAR). Er werd geen significant effect op PR2expressie vastgesteld van de LED-behandelingen toegepast na de meeldauwinoculatie. De LEDbehandelingen voorafgaande aan de meeldauwinoculatie daarentegen vertoonden een zeer sterk significant effect op de PR2-expressie. Gemiddeld was de PR2-expressie van de groepen die voorafgaande aan de meeldauwinfectie met rood stuurlicht waren belicht hoger dan die van de corresponderende controlegroepen (geen LED vóór inoculatie); de PR2-expressie van de groepen die voorafgaande aan de meeldauwinoculatie aan verrood stuurlicht bloot stonden vertoonden gemiddeld de laagste PR-inductie (figuur 4.24). Tevens was er een significante interactie van INA met de LED-behandeling vóór meeldauwinoculatie.

\begin{tabular}{rl|c|c|c|c|c|c|c|c|} 
Na inoculatie: & Geen LED & Verrood & Rood & Geen LED & Verrood & Rood & Geen LED & Verrood & Rood \\
Vóór inoculatie: & \multicolumn{3}{|c|}{ Geen LED } & \multicolumn{3}{c|}{ Verrood } & \multicolumn{3}{c|}{ Rood } \\
\hline
\end{tabular}

25

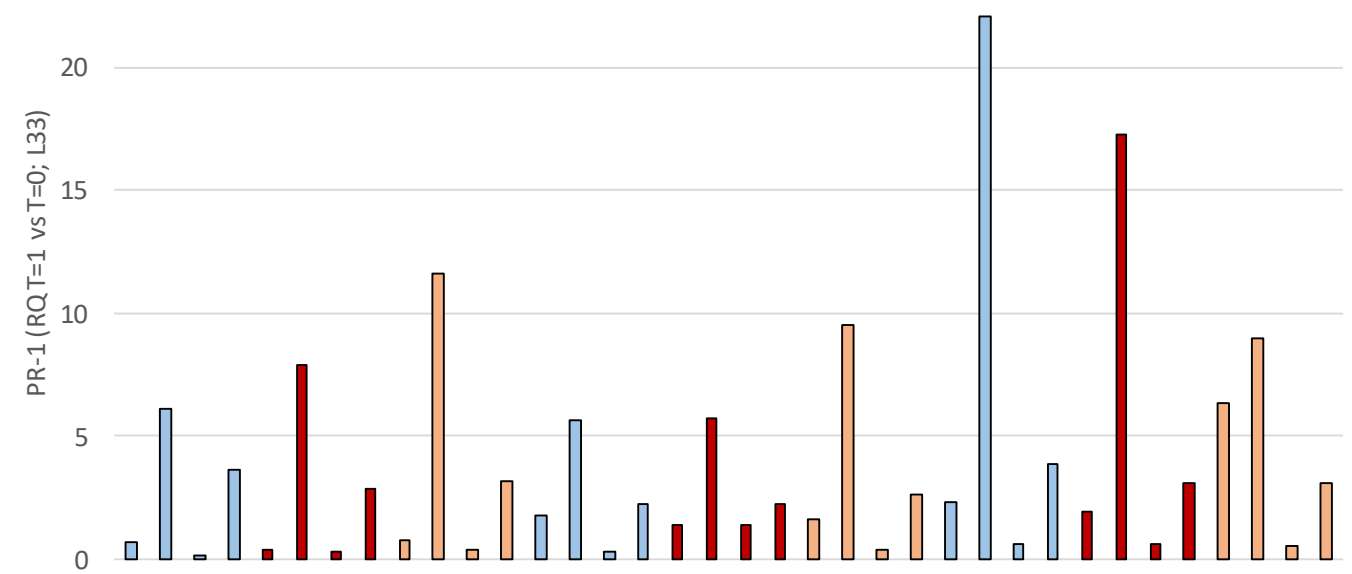

\begin{tabular}{|c|c|c|c|c|c|c|c|c|c|c|c|c|c|c|c|c|c|c|} 
PAR (daglicht): & $30 \%$ & $100 \%$ & $30 \%$ & $100 \%$ & $30 \%$ & $100 \%$ & $30 \%$ & $100 \%$ & $30 \%$ & $100 \%$ & $30 \%$ & $100 \%$ & $30 \%$ & $100 \%$ & $30 \%$ & $100 \%$ & $30 \%$ & $100 \%$ \\
\hline
\end{tabular}

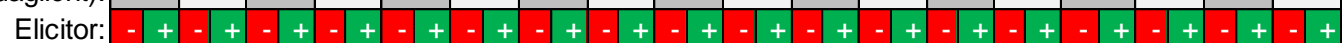

Figuur 4.25 De relatieve toename van PR1-expressie tussen $T=0$ (vlak voor meeldauwinoculatie) en $T=1$ (een week na meeldauwinoculatie), genormaliseerd ten opzichte van de expressie van het huishoudgen L33. De bij elke kolom behorende combinatie van 4 behandelingen is af te lezen boven de grafiek (LED-regime voor en na meeldauwinoculatie) en onder de grafiek (PAR-hoeveelheid en geen INA (rood '-')/wel INA (groen '+')). Lsd=7.718; $n=4$.

Figuur 4.25 en 4.26 tonen de relatieve hoeveelheid van het gemeten PR1-RNA op T=1 (zes dagen na meeldauwinoculatie) ten opzichte van $\mathrm{T}=0$ (enkele uren vóór meeldauwinoculatie), waarbij genormaliseerd is ten opzichte van de expressie van het 'huishoudgen' L33 (figuur 29) en het 'huishoudgen' Ef1a (figuur 30). De sterkste bijdrage aan de PR1-inductie werd geleverd door de behandeling met INA. Daarnaast werd er zowel na normalisatie van PR1 tegen L33 als tegen Ef1a een significant effect gevonden van PAR en een significante interactie tussen PAR en INA-behandeling: bij het lage PAR-niveau (30\% PAR) was de PR1-inductie van INA in alle groepen iets sterker dan bij het hoge PAR-niveau (100\% PAR). Er werd geen significant effect op PR1-expressie vastgesteld van de LED-behandelingen toegepast na de meeldauwinoculatie. De LED-behandelingen voorafgaande aan de meeldauwinoculatie daarentegen vertoonden een significant effect op de PR1-expressie genormaliseerd tegen L33. Gemiddeld was de PR1expressie van de groepen die voorafgaande aan de meeldauwinfectie met rood stuurlicht waren belicht hoger dan die van de corresponderende controlegroepen (geen LED vóór inoculatie); de PR1-expressie van de groepen die voorafgaande aan de meeldauwinoculatie aan verrood stuurlicht bloot stonden vertoonden gemiddeld de laagste PR-inductie (figuur 4.25). Dit effect was echter niet significant wanneer de PR1-expressie genormaliseerd werd tegen expressie van het 'huishoudgen' Ef1a (figuur 4.26). 


\begin{tabular}{rl|l|l|l|l|c|c|c|c|} 
Na inoculatie: & Geen LED & Verrood & Rood & Geen LED & Verrood & Rood & Geen LED & Verrood & Rood \\
\hline Vóór inoculatie: & \multicolumn{3}{|c|}{ Geen LED } & \multicolumn{3}{c|}{ Verrood } \\
\hline
\end{tabular}

30

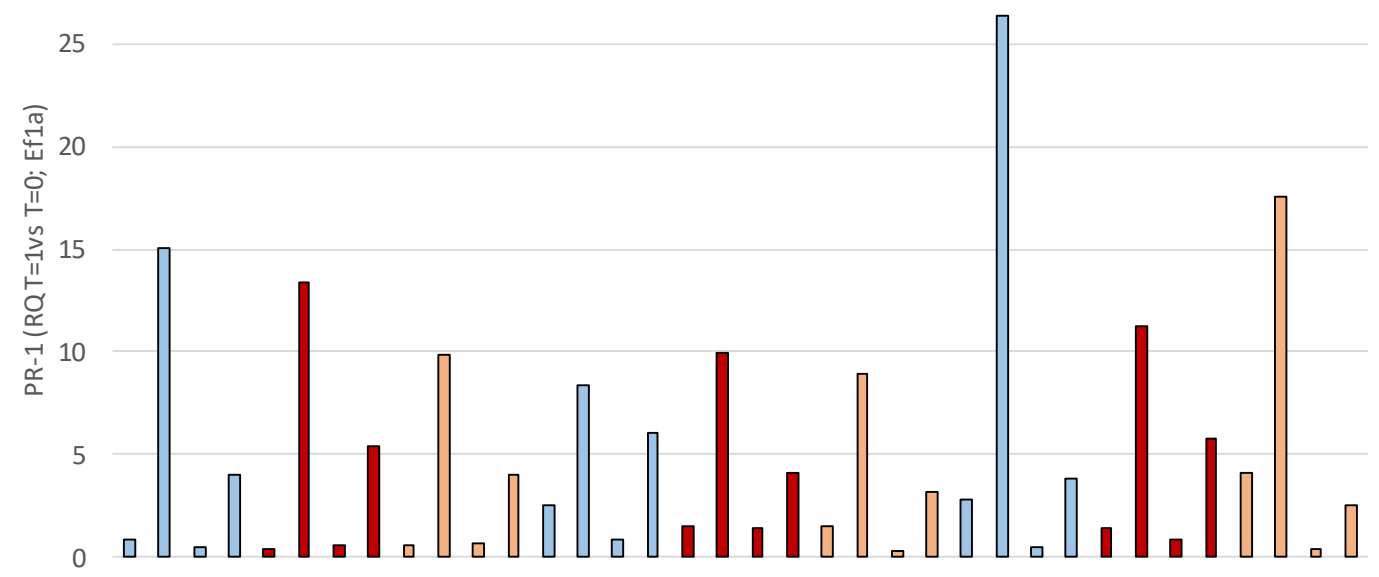

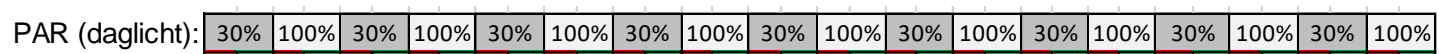

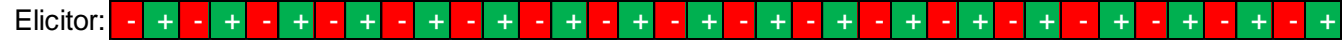

Figuur 4.26 De relatieve toename van PR1-expressie tussen $T=0$ (vlak voor meeldauwinoculatie) en $T=1$ (een week na meeldauwinoculatie), genormaliseerd ten opzichte van de expressie van het huishoudgen Ef1a. De bij elke kolom behorende combinatie van 4 behandelingen is af te lezen boven de grafiek (LED-regime voor en na meeldauwinoculatie) en onder de grafiek (PAR-hoeveelheid en geen INA (rood '-')/wel INA (groen '+')). Lsd=9.667; $n=4$.

De salicylzuur(SA)-gehaltes bleken opnieuw allemaal zeer laag ( $<1 \mathrm{ng} / \mathrm{g}$ versgewicht; zie figuur 4.27). Het tijdstip ( $T=0$ vs $T=1$ ) had een significant effect op de SA-gehaltes: na meeldauwinoculatie werden hogere SA-gehaltes gevonden. Op grond van literatuurgegevens was de verwachting (paragraaf 4.3.1) dat onder hogere PAR hogere SA-gehaltes gevormd zouden worden. Dat bleek overwegend het geval te zijn (figuur 4.27), maar dit PAR-effect was net niet significant. Wel werd een significant INA-effect gevonden, waarbij het opmerkelijk is dat de groepen die niet met INA behandeld waren een hoger SA-gehalte bezaten.

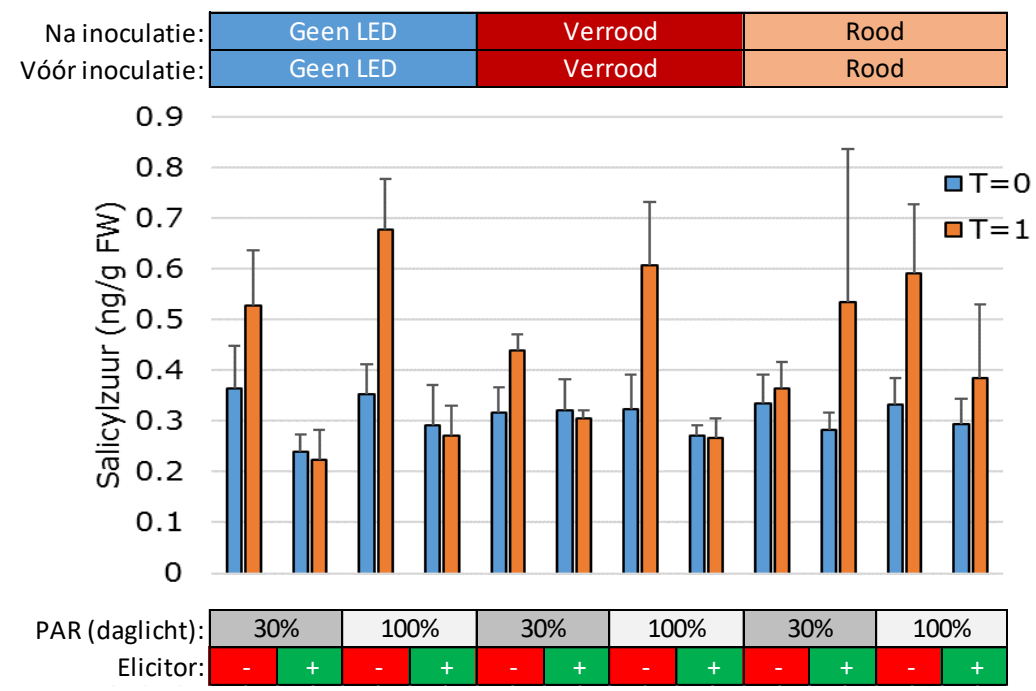

Figur 4.27 Gehalte vrij salicylzuur enkele uren voor $(T=0)$ en een week na $(T=1)$ meeldauwinoculatie, uitgedrukt in ng per $g$ versgewicht bladmonster. De bij elke kolom behorende combinatie van 4 behandelingen is af te lezen boven de grafiek (LED-regime voor en na meeldauwinoculatie) en onder de grafiek (PAR-hoeveelheid en geen INA (rood '-')/wel INA (groen ' + ')). Lsd=0.135; $n=4$. 
De meeldauw ontwikkelde zich in alle behandelingsgroepen als witte, uniforme myceliumvlekjes van ongeveer gelijke grootte. Dit maakte het mogelijk om de meeldauwschade te kwantificeren door het tellen van de absolute aantallen vlekjes. De meeste vlekjes waren aanwezig op het tweede samengestelde blad (geteld vanaf de cotylen), wat de waarneming op dit blad-etage nauwkeuriger maakte. Omdat grote bladeren meer inoculum opvangen dan kleinere, is gecorrigeerd voor de verschillen in bladoppervlakte die ten tijde van het inoculeren ontstaan waren als gevolg van de verschillende belichtingsbehandelingen, wat resulteerde in relatieve dichtheden van meeldauwvlekken. Figuur 4.28 toont de dichtheden van meeldauwvlekken op het tweede blad-etage van de plantengroepen die blootgesteld waren aan de 36 verschillende behandelingscombinaties. Er werd een significant INA-effect gevonden, waarbij de groepen die met INA behandeld waren een lagere meeldauwdichtheid vertoonden dan de onbehandelde groepen. Ook was er een significant PAR-effect: minder meeldauw bij hogere PAR. Interessant was het significante effect van de LED-belichting vóór inoculatie. Evenals met PR2- en PR1expressie correleerde deze factor in de volgorde van verrood stuurlicht - geen stuurlicht - rood stuurlicht positief met de onderdrukking van meeldauwschade. En ook hier werd geen significant effect gevonden van de LED-belichting na inoculatie.

\begin{tabular}{|c|c|c|c|c|c|c|c|c|c|}
\hline & LED & Verrood & Rood & Geen LED & Verrood & Roo & Geen LED & Verrood & Rood \\
\hline
\end{tabular}

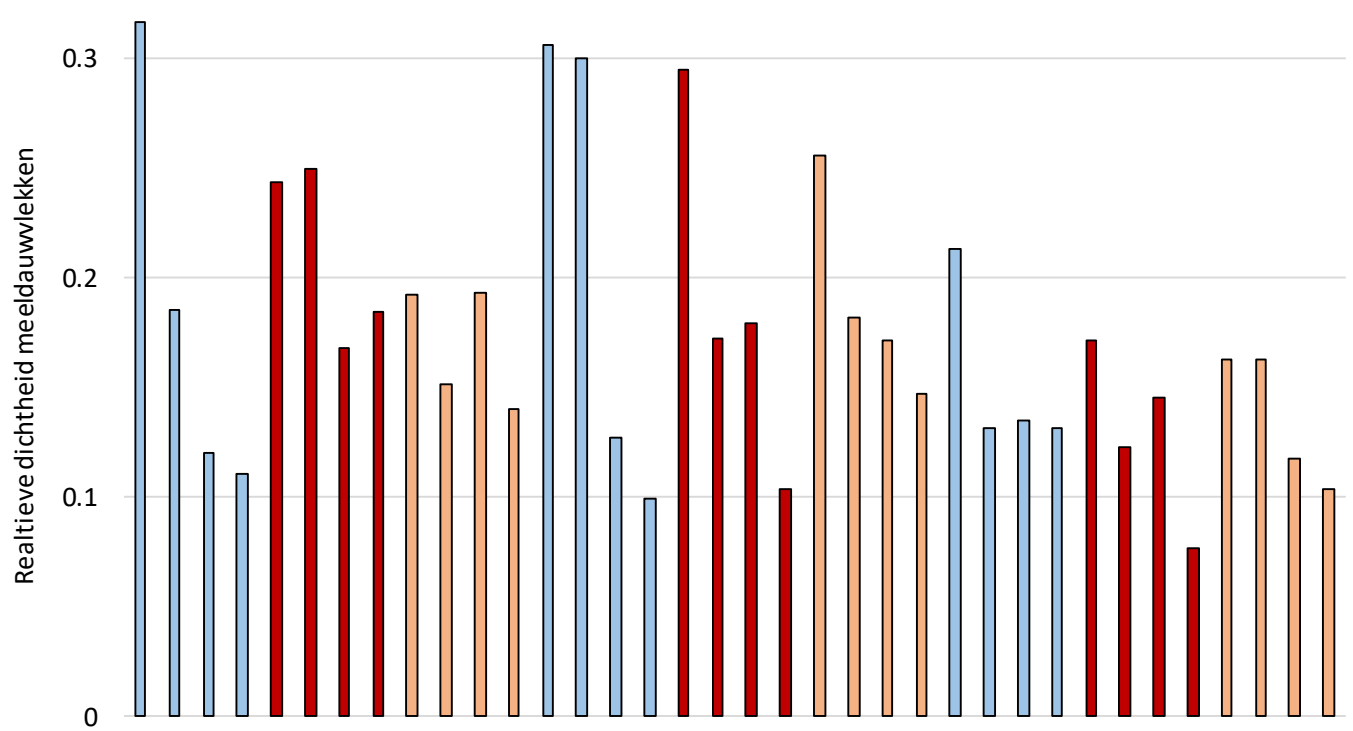

PAR (daglicht): \begin{tabular}{|c|c|c|c|c|c|c|c|c|c|c|c|c|c|c|c|c|c|}
$30 \%$ & $100 \%$ & $30 \%$ & $100 \%$ & $30 \%$ & $100 \%$ & $30 \%$ & $100 \%$ & $30 \%$ & $100 \%$ & $30 \%$ & $100 \%$ & $30 \%$ & $100 \%$ & $30 \%$ & $100 \%$ & $30 \%$ & $100 \%$ \\
\hline
\end{tabular}

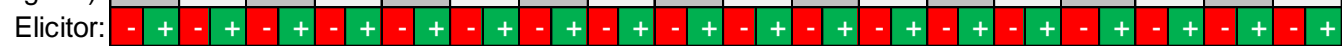

Figuur 4.28 Relatieve dichtheid van meeldauwvlekken op het tweede blad-etage van de plantengroepen die blootgesteld waren aan de 36 verschillende behandelingscombinaties. De bij elke kolom behorende combinatie van 4 behandelingen is af te lezen boven de grafiek (LEDregime voor en na meeldauwinoculatie) en onder de grafiek (PAR-hoeveelheid en geen INA (rood '-')/wel INA (groen '+')). Lsd=0.131; $n=4$.

In dit kasexperiment is geprobeerd de fase voorafgaande aan meeldauwinoculatie en de fase daarna van elkaar te onderscheiden. De resultaten wijzen er op dat de PR2-expressie beïnvloedt wordt door de LED-belichting in de eerste fase, en niet door de LED-belichting in de tweede fase. Dit leek ook het geval te zijn voor de PR1-expressie (genormaliseerd tegen L33). Mogelijk staat de receptiviteit van de plant voor de SAR-elicitor onder controle van het fytochroom, of is het primings-mechanisme dat door de elicitor in gang gezet wordt door fytochroom gereguleerd. In dit beeld past de waarneming dat de meeldauwontwikkeling eveneens beïnvloedt wordt door het stuurlicht dat werd toegediend vóór meeldauwinoculatie. Dat er geen LED-effect toegediend na inoculatie werd waargenomen, suggereert dat de meeldauwontwikkeling ongevoelig is voor 
het toegediende stuurlicht. Opmerkelijk is dat de SA-gehaltes onveranderlijk relatief laag waren en negatief correleerde met de INA-behandeling. De sterke afhankelijkheid van het PAR-niveau op de SA-productie zoals voor andere systemen gerapporteerd, kon hier niet bevestigd worden, hoewel PAR wel een duidelijk effect had op SAR-expressie en meeldauwschade. Mogelijk wordt SAR niet slechts door SA-gehaltes maar ook in belangrijke mate door de gehaltes (of de receptiviteit) van SA-receptoren gereguleerd, of vindt modulatie van het SAR-signaal downstream van SA plaats. Hoe dan ook, de SA-gehaltes vormen een slechte voorspeller van de SAR-respons.

\subsection{Effect van stuurlicht voor en na priming}

\subsubsection{Inleiding}

In het kasexperiment beschreven in hoofdstuk 4.3 werd onderzocht of de fase voorafgaand aan meeldauwinoculatie met betrekking tot de reactie op rood stuurlicht onderscheiden kan worden van de fase na meeldauwinfectie. De resultaten wezen op een onderscheid: de expressie van PR1 en PR2, en de bescherming tegen meeldauw bleken verhoogd door toediening van rood stuurlicht in de fase voorafgaand aan meeldauwinoculatie, terwijl geen effect van rood stuurlicht op deze variabelen gevonden werd bij toediening in de fase na meeldauwinoculatie. Om meer duidelijkheid over het mechanisme te verkrijgen, werd in het hier te bespreken experiment geprobeerd om de fase voorafgaande aan meeldauwinoculatie verder op te splitsen, namelijk in de fase voorafgaande aan priming (fase $A$ in figuur $X$ ), en de fase tussen priming en meeldauwinoculatie (fase $B$ in figuur 4.29). Mogelijk beïnvloedt stuurlicht de receptiviteit voor elicitors, of worden de processen die door priming geïnitieerd worden gestimuleerd of geremd door stuurlicht. Om fase A en B van elkaar te kunnen onderscheiden, werden groepen tomatenplanten onder verschillende stuurlichtregimes opgekweekt en na behandeling met elicitor over de verschillende stuurlichtbehandelingen herverdeeld. Vanaf het moment van meeldauwinoculatie werden de stuurlichtbehandelingen bij alle plantgroepen uitgeschakeld, zodat na meeldauwinoculatie slechts de normale PAR-belichting (daglicht) overbleef. De proef werd in 4-voud uitgevoerd met 3 elicitors (INA, BABA en Inssimo) en een onbehandelde controlegroep.

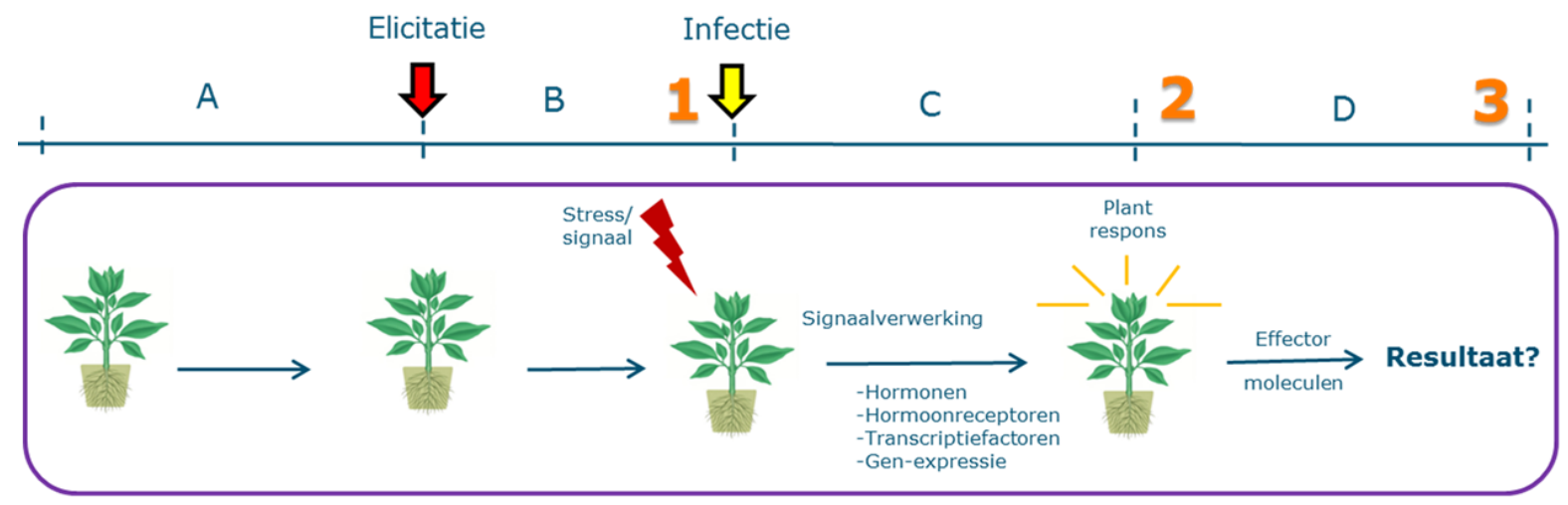

Figuur 4.29 Stuurlichtbehandeling gedurende de fase voorafgaande aan priming (elicitatie; fase $A$ ) beïnvloedt mogelijk andere processen dan gedurende de fase tussen priming en meeldauwinoculatie (fase $B$ ). In dit experiment werden gedurende fase $A$ en $B$ verschillende stuurlichtkwaliteiten toegepast gedurende fase $A$ en $B$, terwijl gedurende fase $C$ en $D$ (de periode na meeldauwinoculatie) géén stuurlicht werd toegediend. 


\subsubsection{Uitvoering van het experiment}

Het experiment vond plaats in september/oktober 2018 in een kascompartiment (144 $\mathrm{m}^{2}$ ) van Wageningen UR te Bleiswijk. Het gewas was tomaat (cv Komeett, bij de start ca 5 weken oud vanaf zaaidatum). Het experiment was opgezet in 4 blokken van elk drie roltafels, waarvan steeds één tafel was voorzien van rode LED-modules $\left(5 \mu \mathrm{mol} . \mathrm{m}^{-2} \cdot \mathrm{s}^{-2}\right.$ op $30 \mathrm{~cm}$ boven de tafel), één tafel was voorzien van verrode LED-modules $\left(50 \mu \mathrm{mol} . \mathrm{m}^{-2} \cdot \mathrm{s}^{-2}\right.$ op $30 \mathrm{~cm}$ boven de tafel), en één tafel was voorzien van dummy-armaturen die geen licht afgaven. De LED-modules en armaturen hingen op 2 meter boven de tafels en waren aangeschakeld van 7:00 tot 24:00 uur. De tafels waren onderling van elkaar afgeschermd met lichtdichte kunststof gordijnen aangebracht aan de oost-, west- en noordzijde van elke tafel, zodanig dat LED-licht niet naastgelegen tafels kon bereiken. De planten ontvingen daglicht, niet aangevuld met PARbijbelichting.

Gedurende het experiment stonden op elk van de twaalf roltafels 60 planten (6 rijen van 10), individueel opgepot in potgrond. Van elk van de acht groepen die met rode en verrode LEDs werden belicht, werden gedurende het experiment 24 planten behandeld en bemonsterd, en van elk van de vier controle-groepen die geen LED-licht ontvingen werden gedurende het experiment 36 planten behandeld en bemonsterd. De overige planten fungeerden als randrijen. De te bemonsteren planten waren voorzien van labels zodat hun posities in het compartiment te herleiden waren. De planten ontvingen standaardvoedingsoplossing middels eb- en vloedgift. Temperatuursinstellingen waren $20^{\circ} \mathrm{C}$ van 9:00 - 18:00 uur en $18^{\circ} \mathrm{C}$ van 18:00 - 9:00 uur.

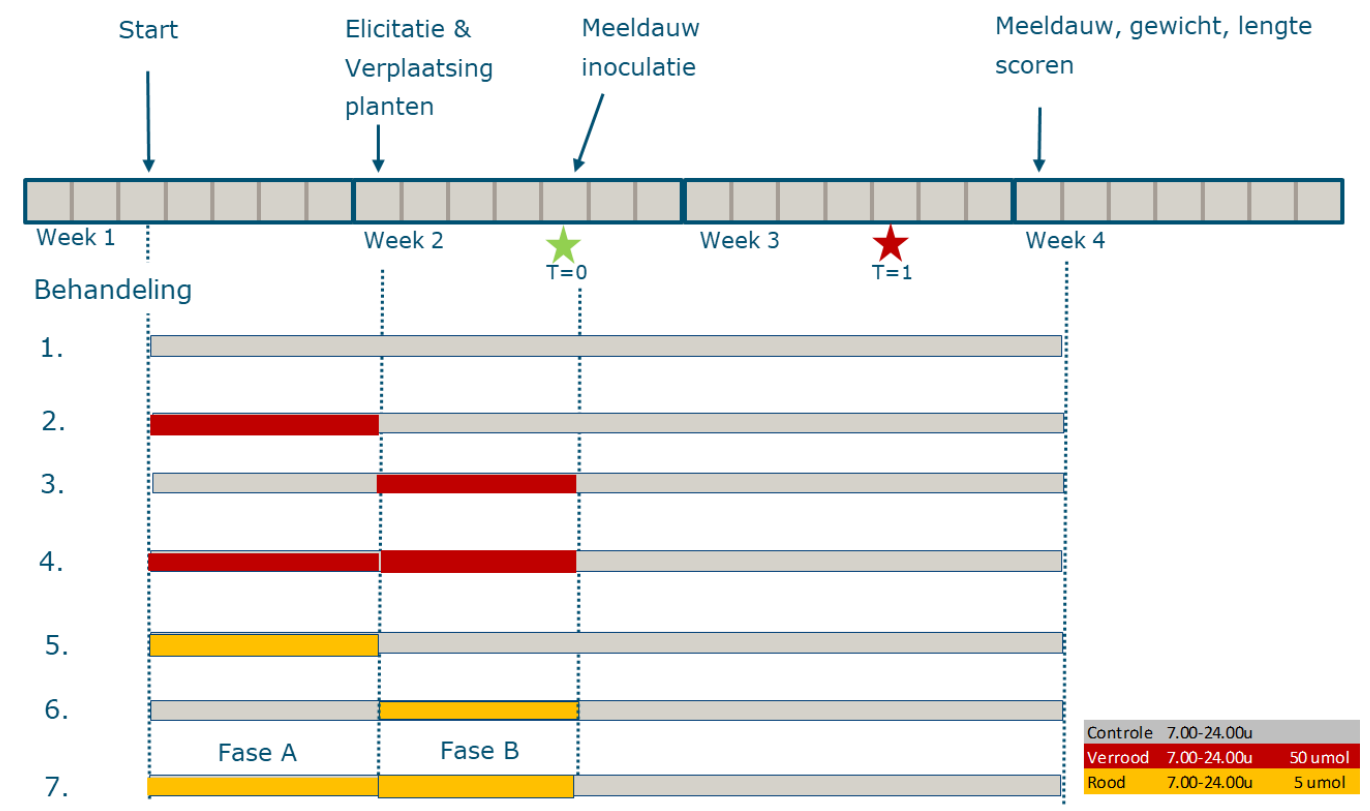

Figur 4.30 Chronologisch schema van de proefopzet. De planten ondergingen in de week voorafgaande aan elicitatie (fase A) rode, verrode of geen LED-stuurlicht. In de week na elicitatie tot aan de inoculatie met meeldauw stonden de planten bloot aan hetzelfde LEDregime, òf aan een variant daarvan (door ze binnen elk blok van roltafel te wisselen). Op deze wijze werden zeven verschillende $L E D$-behandelingen verwezenlijkt. In de ochtend van de meeldauwinoculatie (die 's middags werd uitgevoerd) werden bladmonsters genomen $(T=0)$. Een week later werden opnieuw bladmonsters genomen $(T=1)$. Ongeveer 11 dagen na meeldauwinoculatie werd de meeldauwbedekking gescoord (aantal meeldauwvlekjes per $4^{\text {de }}$ samengesteld blad, geteld vanaf de cotylen) en gewicht en lengte van het bovengrondse plantdeel opgemeten.

De proef werd gestart door de circa 5 weken oude planten onder de verschillende lichtregimes op de roltafels te plaatsen. Na circa 1 week werden tussen 9:00 en 12:00 uur de desbetreffende groepen met elicitor behandeld. INA $(1 \mathrm{mM})$ werd toegediend middels bladbespuiting van de 
onderste twee echte bladeren; BABA ( $5 \mathrm{mM}$ ) en Inssimo (in de voorgeschreven etiketdosering van $50 \mathrm{mg}$ per liter) werden toegediend door bespuiting van de gehele bovengrondse plant. Aldus ontstonden binnen elk blok 4 groepen (INA, BABA, Inssimo, en onbehandeld) van elk 6 planten onder rood en verrood licht, en van elk 9 planten zonder LED-belichting. Dezelfde dag vond binnen elk van de 4 blokken herverdeling van de planten plaats over de tafels (zie figuur 4.31), waarbij per groepje er 3 planten van tafel wisselde. Met deze herverdeling werd bereikt dat de zeven LED-behandelingen ( $1 \mathrm{t} / \mathrm{m} \mathrm{7}$, zie figuur 4.31) verwezenlijkt werd: behandelingen met al dan niet rood, verrood, of geen LED-belichting in procesfase A en B. Gedurende dit verhuisproces ondervond elke plant minstens één onvermijdelijke fysieke verplaatsing binnen dezelfde tafel. Vier dagen na priming werden in de ochtend $(T=0)$ van elke plantgroep uniforme mengmonsters genomen aan het uiteinde van het bovenste volledig gestrekte samengestelde blad, onmiddellijk ingevroren en bij $-80^{\circ} \mathrm{C}$ bewaard voor monsteranalyse. In de namiddag van dezelfde dag $(\mathrm{T}=0)$ werd het gehele gewas met echte meeldauw (Oidium lycopersicum) geïnoculeerd (homogene bespuiting met $7.5 \times 10^{3}$ conidia per $\mathrm{ml}$ suspensie, vers bereid uit met echte meeldauw aangetaste tomatenplanten). Op de dag voorafgaande aan de meeldauwinoculatie werden per tafel bij 10 planten uit de randrijen de bladoppervlakten bepaald van het $3^{\text {de }}$ en $4^{\text {de }}$ samengestelde blad (bladetage geteld vanaf de cotylen). Zeven dagen na meeldauwinoculatie $(T=1)$ werden van elke plantgroep uniforme mengmonsters genomen aan het uiteinde van het bovenste volledig gestrekte samengestelde blad, onmiddellijk ingevroren en bij $-80^{\circ} \mathrm{C}$ bewaard voor monsteranalyse. Tien dagen na meeldauwinoculatie werd bij alle planten de meeldauwaantasting van het gehele $4^{\text {de }}$ blad (bladetage geteld vanaf de cotylen) bepaald door telling van het aantal aanwezige meeldauwvlekjes per samengesteld blad. Tevens werden plantlengtes en versgewichten van het bovengrondse plantdeel bepaald. De bladmonsters werden geanalyseerd op expressie van PR-1 en PR-2.

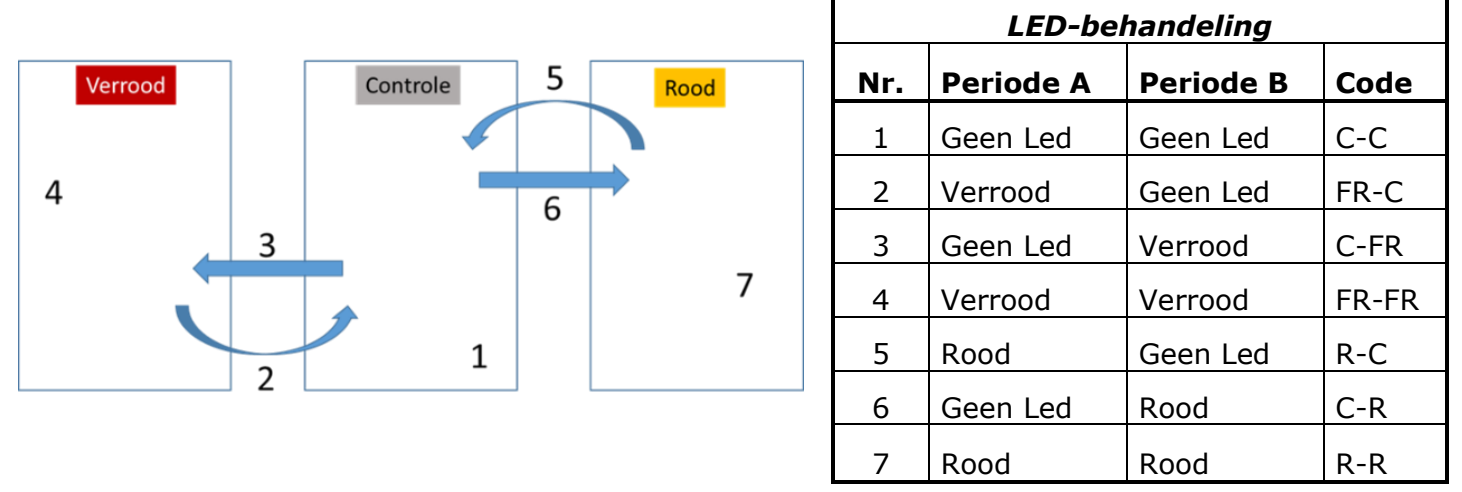

Figuur 4.31 Schematische weergave van de verplaatsing van de planten (links) resulterend in de verschillende LED-behandelingen (rechts). Op de dag waarop de planten geprimed werden met elicitors, werden per blok steeds 3 planten per elicitor-groepje van de tafel zonder LEDbelichting omgewisseld met een corresponderend groepje van 3 planten van de tafels die met rood en met verrood LED-licht belicht werden. Tegelijkertijd bleven op elke tafel 3 planten per elicitor-groepje staan. Op deze wijze ontstonden per elicitor-behandeling 7 groepen planten die de verschillende $L E D$-regimes ondergingen zoals weergegeven in de tabel rechts.

\subsubsection{Resultaten en conclusies}

Hoewel de dagelijkse LED-behandelingen over een relatieve korte periode toegepast waren (tot het moment van meeldauwinoculatie), konden niettemin meetbare LED-effecten terug gevonden worden in de geproduceerde biomassa (versgewicht) en in de lengte van de planten. Figuur 4.32 laat zien dat de groepen die (deels) met rode LEDs belicht waren na afloop van het experiment een wat hoger gemiddeld versgewicht bezaten dan de groepen die geen LEDbelichting ontvangen hadden of (deels) met verrode LEDs belicht waren. De planten die uitsluitend verrode LED-belichting ontvangen hadden, waren zoals verwacht gemiddeld het meest gestrekt; de lengteverschillen tussen deze groep en de controle groep en de groep die 
uitsluitend rood licht ontvingen zijn echter niet significant (figuur 4.33). Opmerkelijk is dat de groepen die na priming een gewijzigde LED-belichting ondergingen gemiddeld iets minder gestrekt waren dan de groepen die geen LED-belichting, of uitsluitend verrood licht, of uitsluitend rood LED-licht ontvingen (figuur 4.33); de tussentijdse wijziging van stuurlicht rondom het moment van priming lijkt dus een remmend effect te hebben op de plantstrekking.
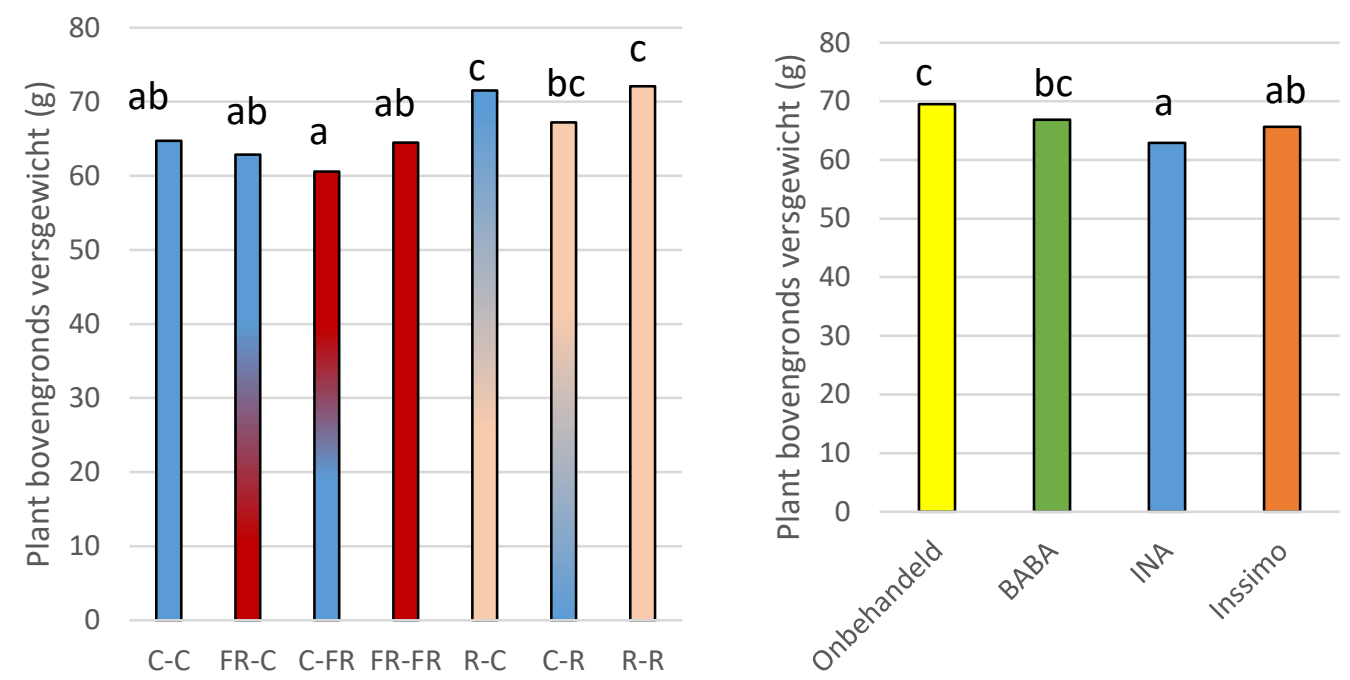

Figuur 4.32 Effecten van de verschillende LED-behandelingen (linkerfiguur) en de verschillende elicitors (rechterfiguur) op het versgewicht van de planten na afloop van het experiment. Codes voor de LED-behandelingen: $C-C=$ geen LED voor en geen LED na priming; $F R-C=$ verrood voor en geen $L E D$ na priming; $C-F R=$ geen $L E D$ voor en verrood na priming; $F R-F R=$ verrood voor en verrood na priming; $R-C=$ rood voor en geen $L E D$ na priming; $C-R=$ geen $L E D$ voor en rood na priming; $R-R$ - rood voor en rood na priming. Waarden met verschillende letters zijn significant verschillend.
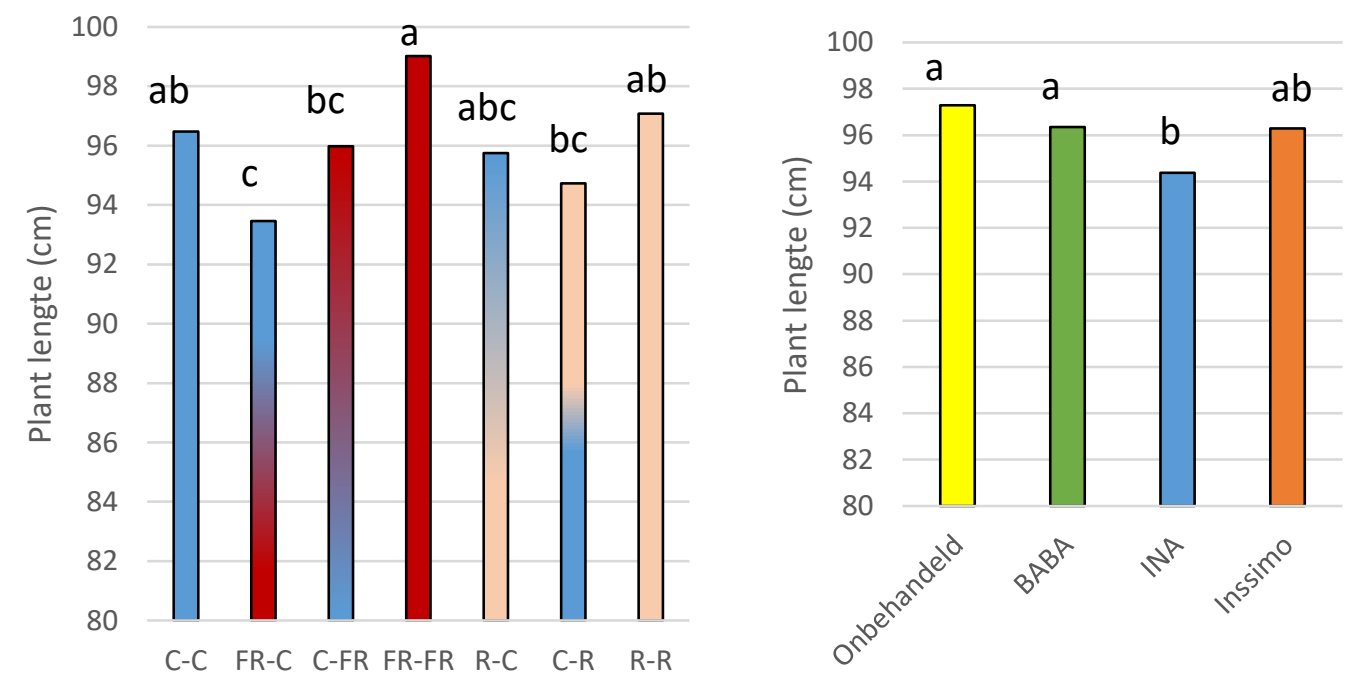

Figuur 4.33 Effecten van de verschillende LED-behandelingen (linkerfiguur) en de verschillende elicitors (rechterfiguur) op de lengte van de planten na afloop van het experiment. $N B$. De verticale assen beginnen bij $80 \mathrm{~cm}$. Codes voor de $L E D$-behandelingen: $C-C=$ geen $L E D$ voor en geen $L E D$ na priming; $F R-C=$ verrood voor en geen $L E D$ na priming; $C-F R=$ geen $L E D$ voor en verrood na priming; $F R-F R=$ verrood voor en verrood na priming; $R-C=$ rood voor en geen $L E D$ na priming; $C-R=$ geen $L E D$ voor en rood na priming; $R-R$ - rood voor en rood na priming. Waarden met verschillende letters zijn significant verschillend. 
Van de toegediende elicitors bleek alleen INA een significant effect op de plantontwikkeling te vertonen: zowel het versgewicht als de plantlengte was ten opzichte van de onbehandelde controlegroepen geringer bij de met INA behandelde groepen (figuur 4.32 en figuur 4.33). Dit negatieve effect op de groei is conform hetgeen in eerdere experimenten gevonden is. Inssimo en BABA vertoonden in dit experiment gemiddeld een gering, niet significant negatief effect op versgewicht en plantlengte.
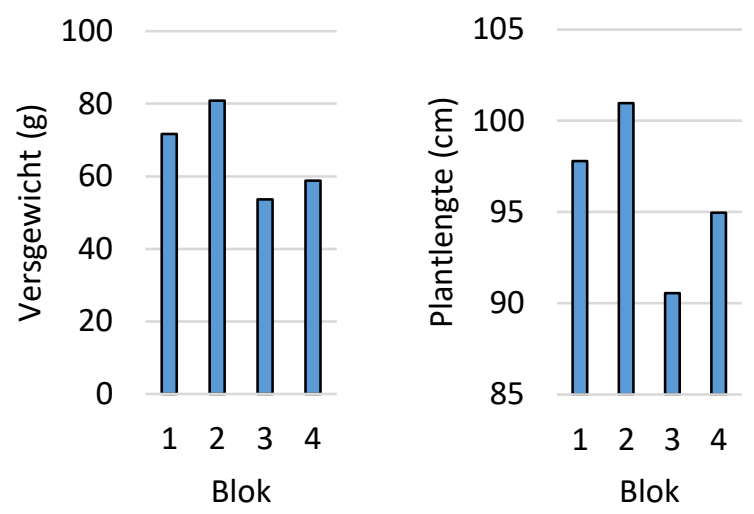

Figuur 4.34 Blokeffecten op gemiddeld versgewicht (linkerfiguur; Isd=3.49) en lengte (rechterfiguur; Isd=1.98) van de planten na afloop van het experiment. NB. De verticale as in de rechterfiguur start op $84 \mathrm{~cm}$.

Behalve LED-regime en toegepaste elicitor bleek ook het blok waarin de planten waren opgesteld een significante factor te zijn voor versgewicht en plantlengte. De planten in blokken 3 en 4, die aan de zuidzijde van het kascompartiment lagen, waren gemiddeld substantieel en significant lichter en korter dan de planten uit blokken 1 en 2, die aan de noordzijde van het kascompartiment lagen (figuur 4.34). Een mogelijke verklaring hiervoor is dat het afgeschermde, naastgelegen compartiment aan de zuidzijde met betrekking tot de langs het zuiden lopende zon aan blokken 3 en 4 meer schaduw bezorgde dan aan blokken 1 en 2 , en dat laatstgenoemde blokken dus meer fotosynthetisch actief licht ontvingen.
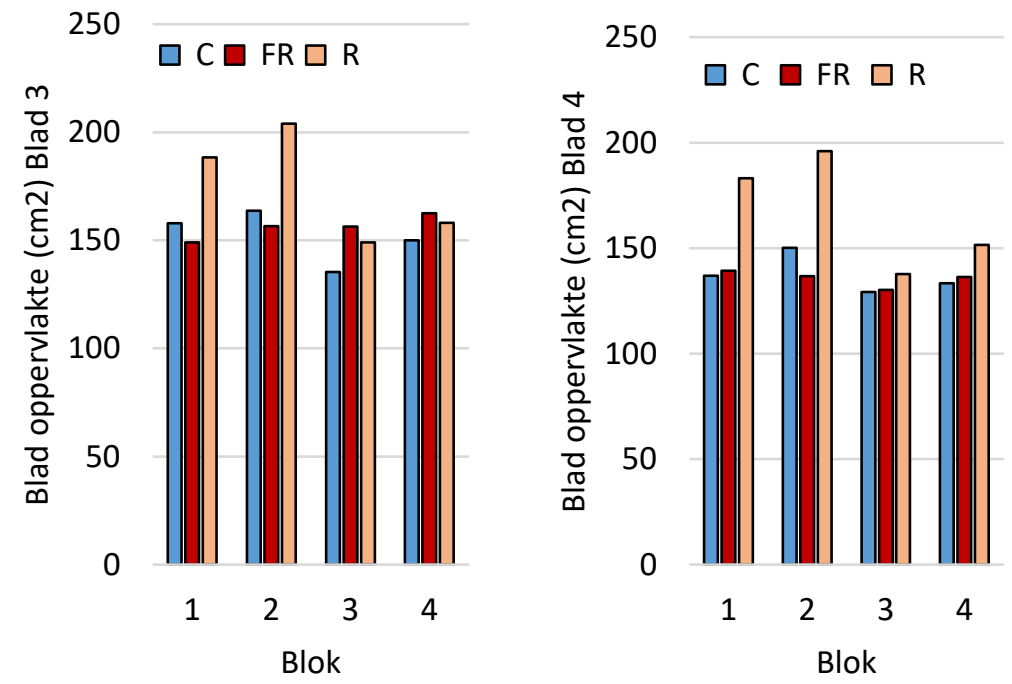

Figuur 4.35 Effecten van de LED-belichting op het bladoppervlakte van het derde samengestelde blad (linkerfiguur; Isd=20) en het vierde samengestelde blad (rechterfiguur; Isd=26), weergegeven per experimenteel blok.

Op de dag voorafgaande aan de meeldauwinoculatie werden bladoppervlakten bepaald, zodat de uiteindelijke meeldauwdichtheid (aantal meeldauwspots per bladoppervlak) berekend kon worden. Omdat het om een destructieve meetmethode ging, werd ze per tafel uitgevoerd op 10 
planten uit de randrijen. Het betreft de oppervlakten van het derde en vierde samengestelde blad (geteld vanaf de cotylen). Figuur 4.35 laat zien dat de oppervlakte-ontwikkeling van deze twee blad-etages significant sterker was onder de rode LED-belichting dan bij de groepen die met verrood of niet met LEDs belicht waren, en dat ook hier sprake was van een blokeffect: blok 1 en 2 vertoonden dit stimulerende effect van rode LEDs wel, en blok 3 en 4 niet.
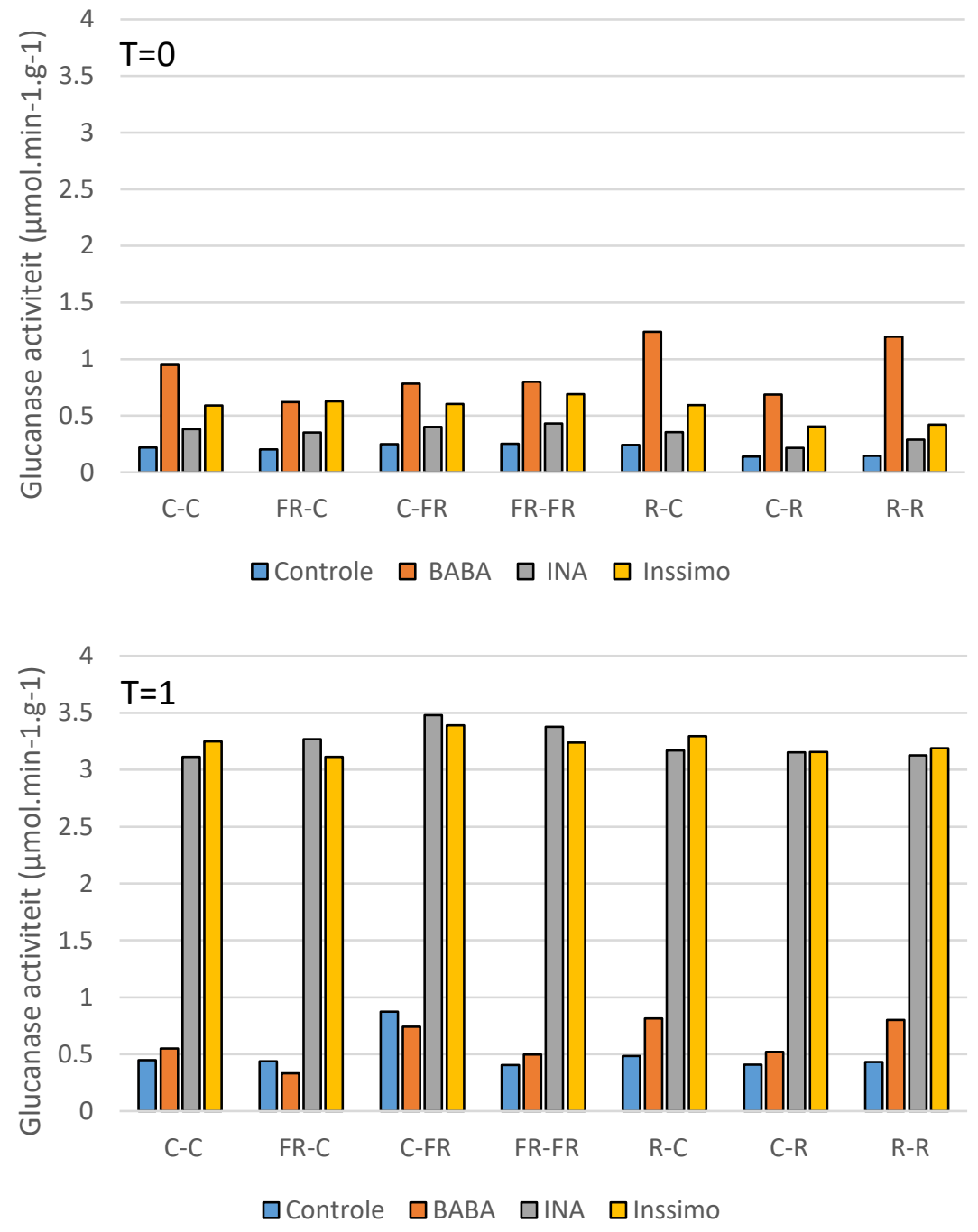

Figuur 4.36 Gemiddelde expressie van glucanase-activiteit (PR-2) als functie van de LEDbehandelingen en toegediende elicitor, gemeten op $T=0$ (bovenste figuur; Isd=0.25) en op $T=1$ (onderste figuur; Isd=0.31), dus vóór $(T=0)$ en na $(T=1)$ meeldauwinoculatie. Zie voor de codes van de $L E D$-behandelingen het onderschrift van figuur 4.32 .

De bovenste grafiek in figuur 4.36 toont de glucanase-activiteit (PR-2) gemeten vier dagen na toediening van de elicitors en voorafgaande aan de meeldauwinoculatie $(T=0)$. Te zien is dat onder alle LED-regimes de plantgroepen die met INA behandeld waren ten opzichte van de onbehandelde controle-groepen een miniem verhoogde glucanase-activiteit bezaten; hetzelfde gold in iets sterkere mate voor de groepen die met Inssimo behandeld waren, en het sterkste gold dit (significant effect) voor de BABA-groepen, met name bij die BABA-groepen die voorafgaande aan de toediening met elicitors aan rood licht hadden blootgestaan (figuur 4.36, bovenste grafiek). De onderste grafiek in figuur 4.36 toont de glucanase-activiteit (PR-2) gemeten zeven dagen nà de meeldauwinoculatie $(T=1)$. Vergelijking van beide grafieken leert dat de glucanase-activiteit onder alle LED-regimes na de meeldauwinoculatie sterk geïnduceerd was in de plantgroepen die met INA en de groepen die met Inssimo behandeld waren; de onbehandelde controle vertoonde in reactie op de meeldauwinoculatie slechts een geringe inductie. Opmerkelijk is dat de glucanase-expressie bij de groepen die met BABA behandeld waren op $T=1$ lager was dan op $T=0$; de expressie lijkt hier dus enigermate afgenomen te zijn 
na meeldauwinfectie. Er werd een gering LED-effect waargenomen: de groepen die na priming belicht waren met verrode LEDS vertoonden een klein, maar niettemin statistisch significant hogere glucanase-activiteit op $T=1$ dan de overige groepen. Figuur 4.37 laat zien dat er nauwelijks blokeffecten waren, en blokken 1 en 2 zich hier nauwelijks onderscheidden van blokken 3 en 4 , zoals wel het geval was met betrekking tot versgewicht en plantlengte.

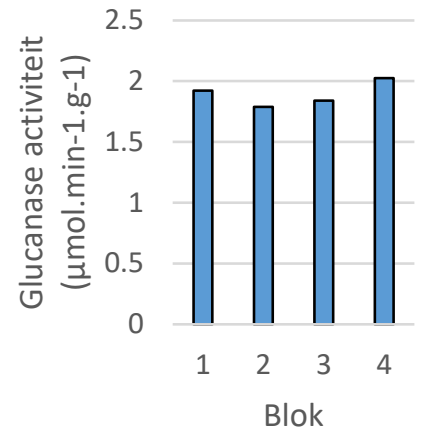

Figuur 4.37 Blokeffect op de glucanase-activiteit gemeten op $T=1 . L s d=0.116$.

Om het effect van de LED- en elicitor-behandelingen op de expressie van PR1 te bepalen, werd de relatieve hoeveelheid PR1-RNA (relatief ten opzichte van de hoeveelheid RNA toebehorend aan min of meer gelijkmatig aanwezige huishoudgenen) bepaald vóór meeldauwinoculatie $(T=0)$ en na meeldauwinoculatie $(T=1)$. Met deze data werd vervolgens de toegenomen relatieve PR1expressie op $\mathrm{T}=1$ berekend ten opzichte van de relatieve PR1-expressie op $\mathrm{T}=0$. Figuur 4.38 toont die toename van PR1-expressie, genormaliseerd met het huishoudgen EF1a, terwijl figuur 4.39 dezelfde data toont verkregen na normalisatie met het huishoudgen $L 33^{1}$. Beide figuren vertonen nagenoeg hetzelfde beeld, met een significant elicitor-effect op de PR1-expressie, die het sterkst was in de plantgroepen behandeld met INA, en het geringst (bijna afwezig) in de groepen behandeld met BABA. Er werd geen significant effect gevonden van de LEDbehandelingen op de PR1-expressie. Wel was de PR1-inductie na priming met INA significant sterker bij de plantgroepen die voorafgaande aan priming rood LED-licht ontvingen ( $R-C)$ dan bij de plantgroepen die voorafgaande aan priming verrood LED-licht ontvingen (FR-C). Dit patroon was echter afwezig bij de groepen die met Inssimo behandeld waren. Er was geen significant blok-effect.

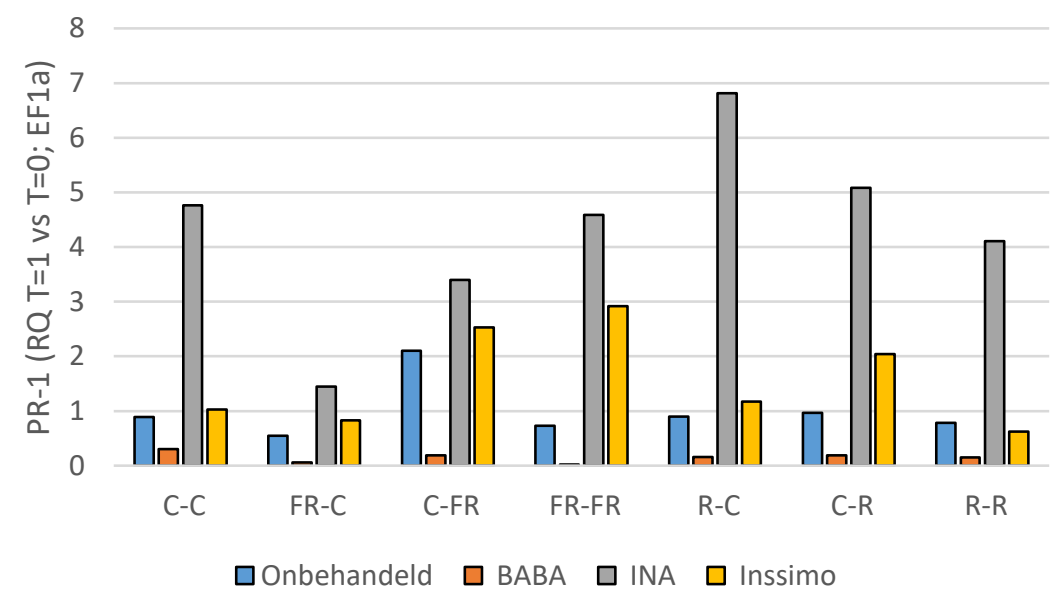

Figuur 4.38 De relatieve toename van PR1-expressie tussen $T=0$ (vlak voor meeldauwinoculatie) en $T=1$ (zeven dagen na meeldauwinoculatie), genormaliseerd ten opzichte van de expressie van het huishoudgen EF1a. Lsd=2.66. Zie voor de codes van de $L E D-$ behandelingen het onderschrift van figuur 4.32 .

\footnotetext{
${ }^{1}$ In beide gevallen werd één en hetzelfde meetpunt, toebehorend aan de INA/C-FR behandeling uit blok 1 , buiten de berekeningen gehouden omdat het hier om een evidente uitbijter ging met respectievelijk een 15 - en 8 -voudige afwijking van het gemiddelde van de herhalingen uit de overige 3 blokken).
} 


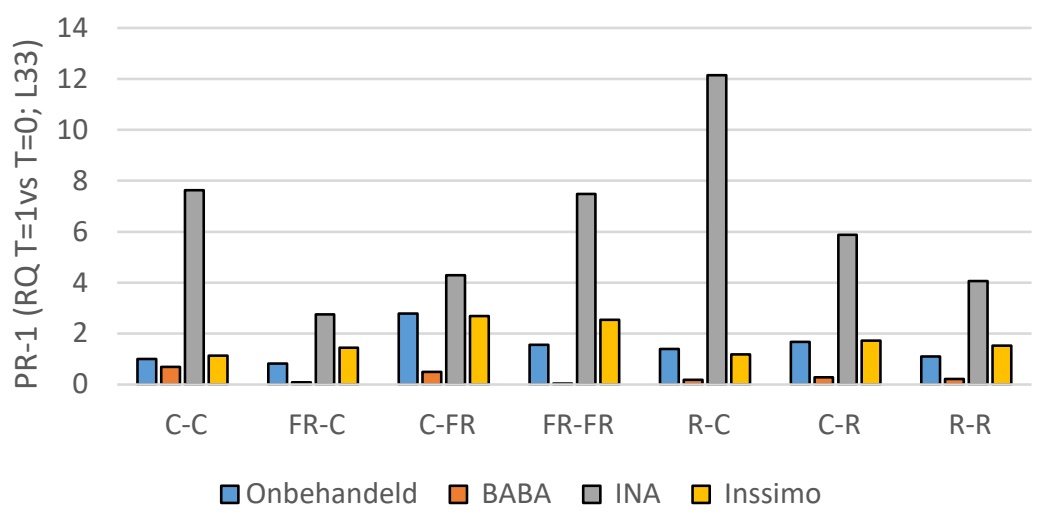

Figuur 4.39 De relatieve toename van PR1-expressie tussen $T=0$ (vlak voor meeldauwinoculatie) en $T=1$ (zeven dagen na meeldauwinoculatie), genormaliseerd ten opzichte van de expressie van het huishoudgen $L 33$. Lsd=5.11. Zie voor de codes van de $L E D-$ behandelingen het onderschrift van figuur 4.32 .

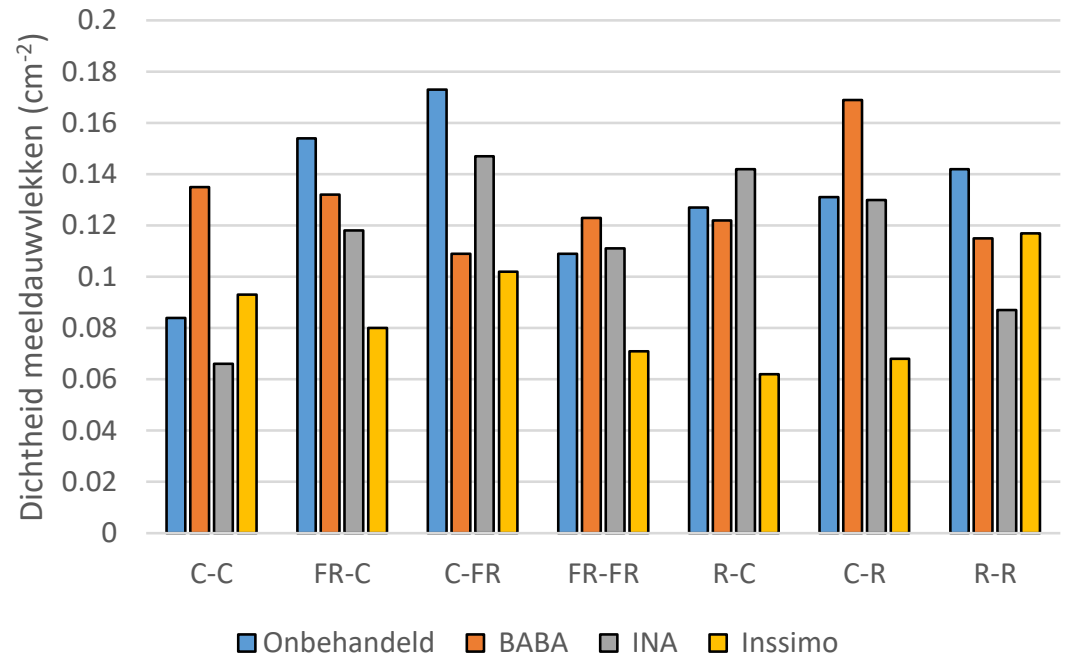

Figuur 4.40 Gemiddelde dichtheden van de meeldauwvlekken op het $4^{\text {de }}$ samengestelde blad tien dagen na inoculatie als functie van de toegediende elicitor en de LED-belichting. $L s d=0.0625$. Zie voor de codes van de LED-behandelingen het onderschrift van figuur 4.32.

Op de tiende dag na meeldauwinoculatie was de meeldauwontwikkeling in het gewas zodanig dat op het vierde samengestelde blad (geteld vanaf de cotylen) uniforme, individuele witte myceliumvlekjes van ongeveer gelijke doorsnede waarneembaar waren in telbare aantallen (tussen 0 en 87 vlekjes per blad). Omdat het aantal conidiën dat tijdens de inoculatie door een blad opgevangen wordt evenredig is met de grootte van het betreffende bladoppervlak op dat moment, dient als maat voor de meeldauwaantasting het aantal vlekken per bladoppervlakte, dus de dichtheid van de meeldauwvlekken, gebruikt te worden. Hiertoe waren de dag voorafgaande aan de meeldauwinoculatie oppervlaktemetingen uitgevoerd aan het $4^{\text {de }}$ blad van 10 planten in de randrijen (figuur 4.35) wat voor elk blok de gemiddelde bladoppervlakte opleverde voor de plantgroepen die bloot stonden aan LED-behandeling 1 (C-C), 4 (FR-FR) en 7 $(R-R)$; de gemiddelde bladoppervlakte voor de plantgroepen die bloot stonden aan LEDbehandeling 2 (FR-C) en 3 (C-FR) werden berekend door het gemiddelde te nemen van die van de groepen 1 en 4 , en de gemiddelde bladoppervlakte voor de plantgroepen die bloot stonden aan LED-behandeling $5(R-C)$ en $6(C-R)$ werden berekend door het gemiddelde te nemen van 
die van de groepen 1 en $7^{2}$. Figuur 4.40 toont voor elke LED/elicitor-behandelcombinatie de gemiddelde $(n=4)$ dichtheden van de meeldauwvlekjes op het $4^{\text {de }}$ blad.

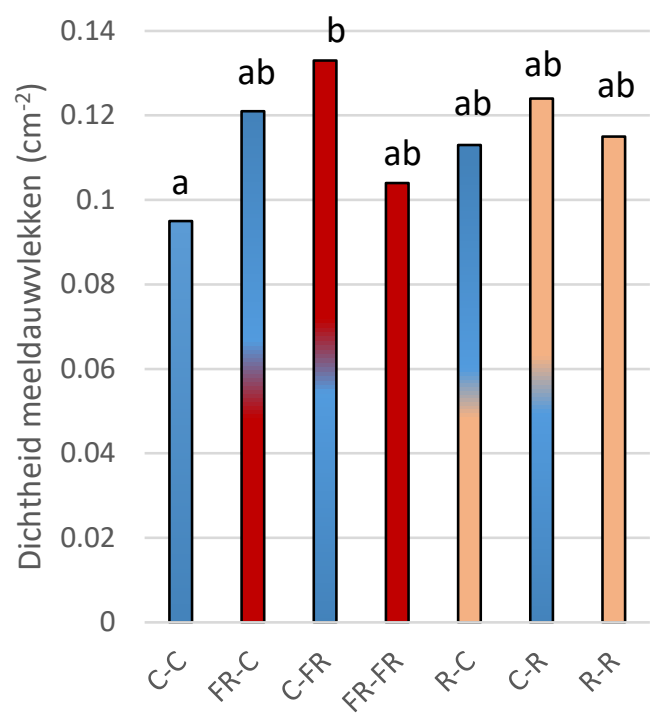

Figuur 4.41 Gemiddelde dichtheden van de meeldauwvlekken op het $4^{\text {de }}$ samengestelde blad tien dagen na inoculatie als functie van de LED-belichting. Waarden met gelijke letters zijn niet significant verschillend. Zie voor de codes van de LED-behandelingen het onderschrift van figuur 4.32 .

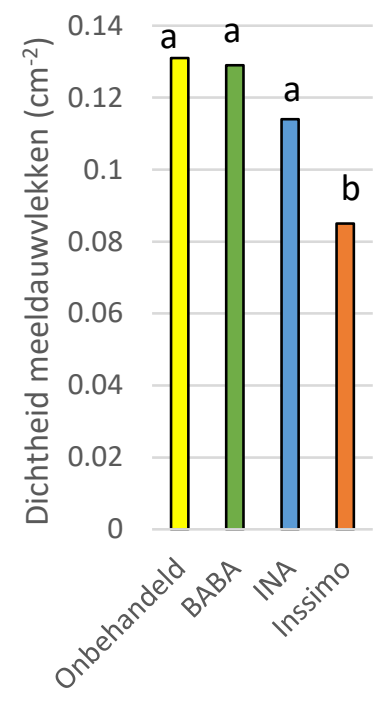

Figur 4.42 Gemiddelde dichtheden van de meeldauwvlekken op het $4^{\text {de }}$ samengestelde blad tien dagen na inoculatie als functie van elicitorbehandeling. Waarden met gelijke letters zijn niet significant verschillend.

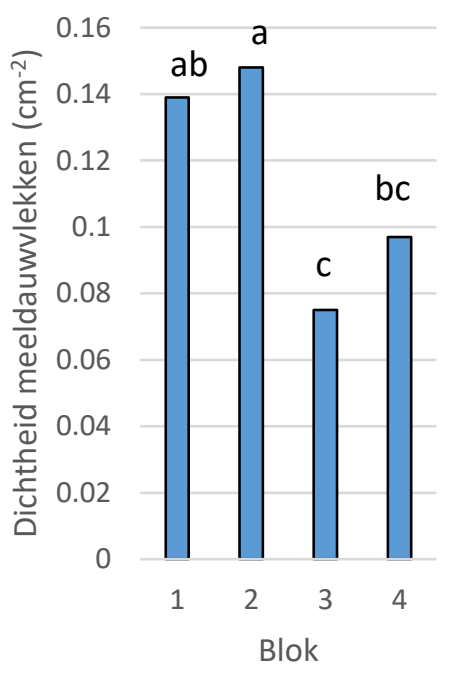

Figuur 4.43 Blok-effecten op de gemiddelde dichtheden van de meeldauwvlekken op het $4^{\text {de }}$ samengestelde blad tien dagen na inoculatie. Waarden met gelijke letters zijn niet significant verschillend.

\footnotetext{
2 Hierbij wordt de aanname gehanteerd dat de verschillen in bladgrootte tussen de groepen uitsluitend ontstaat onder invloed van de LEDs, dus gedurende de periode van LED-toediening, en dat de toename van de bladoppervlakteverschillen lineair in de tijd verloopt.
} 
Er werd geen significant LED-effect ten aanzien van de meeldauwontwikkeling gevonden. Figuur 4.41 toont dat uitsluitend de groepen die geen LED belichting voor èn verrood belichting na priming ontvangen hadden (C-FR) gemiddeld een significant hogere meeldauwdichtheid vertoonden dan de groepen die in het geheel geen LED-belichting (C-C) hadden gekregen.

Er werd een significant effect gevonden van de gebruikte elicitor. De dichtheid van meeldauwvlekjes was in de groepen die behandeld waren met Inssimo gemiddeld $40 \%$ lager dan in de onbehandelde controlegroepen (figuur 4.42); de meeldauwdichtheid in de met INA behandelde groepen was weliswaar gemiddeld lager dan in de onbehandelde groepen, maar dit effect was niet significant; BABA had geen effect (figuur 4.42).

Opvallend was dat de aantallen meeldauwvlekken in de experimentele blokken 1 en 2 bijna twee keer hoger waren dan in blokken 3 en 4, wat resulteerde in een significant blokeffect ten aanzien van de dichtheid van meeldauwvlekken (figuur 4.43). Hierboven werd al een blokeffect vastgesteld ten aanzien van plantlengte en versgewicht, dat vermoedelijk een gevolg was van geringere zoninstraling aan de zuidzijde van het kascompartiment. Een geringere hoeveelheid PAR bevordert echter meeldauwaantasting (zie hoofdstuk 4.3). Omdat de vlekkengrootte in alle blokken min of meer uniform waren, is het waarschijnlijk dat het blokeffect hier toegeschreven moet worden aan verschillen in inoculatiecondities, zoals bijvoorbeeld de in het gewas heersende luchtvochtigheid direct na inoculeren. Nadere analyse van de data wees uit dat dit blokeffect geen wezenlijke invloed heeft op de hierboven beschreven conclusies over LED- en elicitor-effecten op meeldauwontwikkeling.

In dit kasexperiment is geprobeerd LED-stuurlichteffecten in de fase voorafgaande aan priming (fase $A$ in figuur 4.29) en de onmiddellijke fase na priming (fase $B$, tot moment van meeldauwinoculatie) van elkaar te onderscheiden. Op basis van de waarnemingen kan dat onderscheid niet gemaakt worden: er werd immers geen duidelijk LED-effect opgeroepen ten aanzien van SAR-expressie en meeldauwontwikkeling. Verschillen in plantlengte vormen een indicatie of de planten stuurlichtverschillen gedetecteerd en verwerkt hebben: verrood stuurlicht doet planten strekken, rood stuurlicht remt strekking. De lengtegroei van de verschillende plantgroepen in reactie op de zeven verschillende LEDregimes geven geen consistente bevestiging dat dit fytochroom-effect in alle plantgroepen verwezenlijkt is: de tussentijdse wijziging van stuurlicht rondom het moment van priming lijkt in dit experiment in alle gevallen een remmend effect te hebben op de plantstrekking (zie figuur 4.33). Een andere factor die het trekken van conclusies compliceert, zijn de geconstateerde blokeffecten. Wel bevestigt het experiment opnieuw dat toepassing van inducers van SAR tot een substantiële reductie van echte-meeldauwschade kunnen leiden. Hierbij onderscheidde BABA zich van INA en Inssimo wederom als ineffectief: althans met een eenmalige bladtoediening van 5 mM BABA werd onder de omstandigheden van dit experiment geen SAR-inductie en geen meeldauwonderdrukking vastgesteld.

\subsection{Inductie van SAR bij enkele siergewassen onder stuurlicht}

\subsubsection{Inleiding}

In de voorgaande experimenten was het onderzoek voornamelijk uitgevoerd met het modelgewas tomaat. De vraag is hoe de diverse stuurlichtbehandelingen uitpakken op SAR-elicitatie in andere gewassen dan tomaat. In dit experiment werden daarom trays met zaailingen van viola, petunia en gerbera blootgesteld aan rood, verrood of geen stuurlicht en met de elicitor 2,6-dichloro isonicotinezuur (INA) behandeld. In het experiment werden tevens circa 3 weken oude tomatenplanten meegenomen. $\mathrm{Na}$ elicitatie volgde inoculatie met echte meeldauw (tomaat en gerbera). Voor petunia en viola waren geen meeldauw conidia beschikbaar en daarom werden deze plantjes "geïnoculeerd" middels een bespuiting met $0.5 \mathrm{mM}$ salicylzuur. De SAR-respons werd bepaald aan de hand van de glucanaseactiviteit (PR2), waarvan eerder in het project was vastgesteld dat deze ook in viola en petunia goed meetbaar is. Omdat het experiment plaats vond op praktijklokatie van Florensis BV werd het experiment afgebroken vóór het moment dat meeldauwmycelium tot ontwikkeling kwam. 


\subsubsection{Uitvoering van het experiment}

Het experiment vond plaats in november 2016 in een kascompartiment van Florensis BV te Hendrik Ido Ambacht. De proefopstelling (figuur 4.44) omvatte 6 ruime veldjes (ca $5 \times 5 \mathrm{~m}$ ) met van elk gewas 2 trays met zaailingen (Gerbera Revoltion F1 Bicolour Tyellow Orange; Petunia Grandiflora Parade Plus F1 White; Viola F1 Sorbet XP Yellow Blotch Exp), of jonge planten (tomaat cv Komeett in potaarde). De veldjes waren van elkaar gescheiden met lichtdicht folie. Exact midden boven de veldjes hingen LED-lampen die geen licht (Controlegroepen A), rood licht (ca. $5 \mu \mathrm{mol} . \mathrm{s}^{-1} \cdot \mathrm{m}^{-2}$ op tray-hoogte; B) of verrood licht (ca. 5 $\mu \mathrm{mol} . \mathrm{s}^{-1} \cdot \mathrm{m}^{-2}$ op tray-hoogte; C) uitzonden. Deze stuurlichtbehandelingen werden dagelijks toegepast van 7:00 tot 23:00 uur. Verder ontvingen de planten normaal daglicht (november) aangevuld met bijbelichting (100 $\mu \mathrm{mol} . \mathrm{s}^{-1} \cdot \mathrm{m}^{-2}$ ) die aanstond van 4:00 uur s' ochtends tot vóór zonsondergang (ca. 16:00 uur). Twee weken na zaaien werden de planten in het kascompartiment onder de belichting geplaatst. $\mathrm{Na}$ ca. anderhalve week werd aan de helft van de trays de elicitor toegediend. Bij de tomatenplanten gebeurde dit aan de onderste twee echte bladeren; bij gerbera, petunia en viola werd de gehele tray homogeen beneveld. Vier dagen na INA-toediening $(T=0)$ werd $s^{\prime}$ ochtends van elke tray bladmateriaal bemonsterd (mengmonsters van 3 planten van tomaat, van 24 zaailingen van gerbera, van 10 zaailingen van petunia, en van 12 zaailingen van viola). De monsters werden onmiddellijk ingevroren en bevroren bewaard $\left(-80^{\circ} \mathrm{C}\right)$ tot aan het moment van analyse. In de middag van dezelfde dag van de eerste bladoogst werden ter plaatse van geïnfecteerd bladmateriaal van tomaat en gerbera verse suspensies van echte meeldauw-conidia bereid. Deze inocula werden onmiddellijk middels bespuiting aan de tomatenplanten $\left(10^{5}\right.$ conidia/ml) en gerbera-zaailingen $\left(6 \times 10^{4} \mathrm{conidia} / \mathrm{ml}\right)$ toegediend. De zaailingen van petunia en viola werden "geïnoculeerd" middels een bespuiting met $0.5 \mathrm{mM}$ salicylzuur. Zeven dagen na de eerste bladoogst werd de tweede bladmonstername gedaan $(T=1)$, op identieke wijze als de eerste. Na de tweede bladoogst werden bij de tomatenplanten aan gestrekt blad per plant 2 chlorofyl gehalte-bepalingen uitgevoerd g (SPAD-metingen; Minolta SPAD 502 PlusChlorofyl Meter) en werden van elk gewas monsters genomen voor drooggewichtsbepalingen.

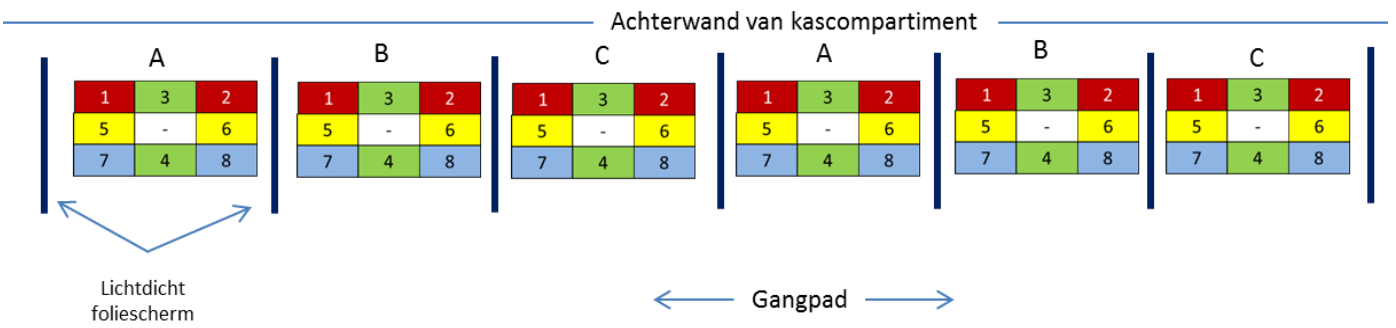

Figuur 4.44 Proefopstelling. Het experiment omvatte 6 veldjes met elk 8 trays ( $1 \mathrm{t} / \mathrm{m}$ 8), namelijk twee trays voor elk gewas. De ene tray werd behandeld met INA, de ander tray bleef onbehandeld met INA.

\subsubsection{Resultaten en conclusies}

De verschillende LED-behandelingen resulteerden in significante verschillen in chlorofylgehalte (figuur 4.45) en significante verschillen in plantlengte tussen enerzijds de met verrood behandelde groepen en anderzijds de controle-groepen en de met rood licht behandelde groepen (figuur 4.46).

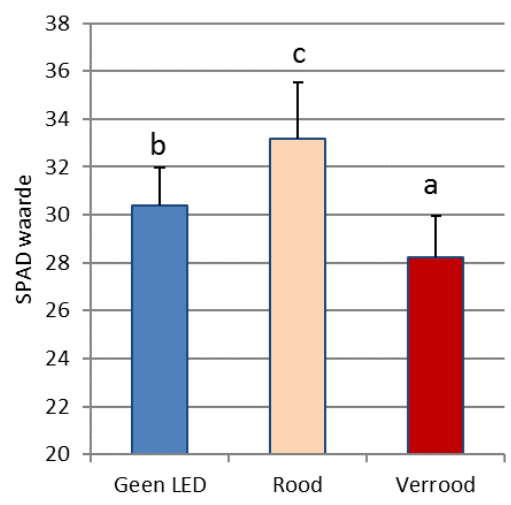

Figuur 4.45 Chlorofylgehalte van de tomatenplanten als functie van de $L E D$-behandelingen, bepaald aan het einde van het experiment, uitgedrukt in SPAD-waarden. Waarden met verschillende letters zijn significant verschillend. 


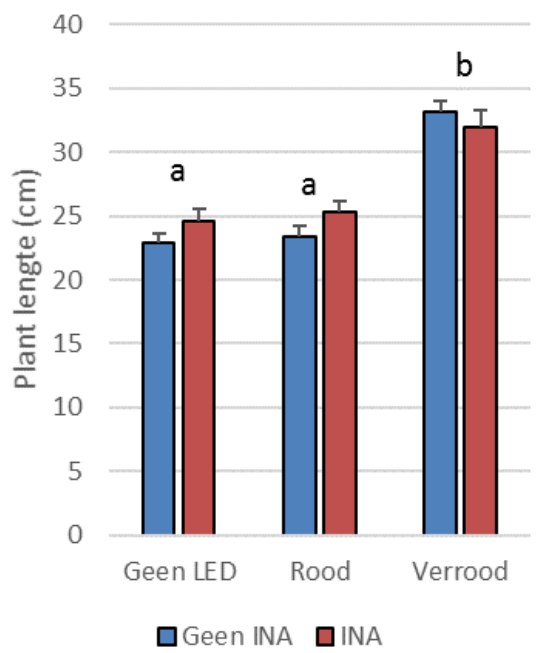

Figuur 4.46 Plantlengte van de tomatenplanten als functie van de LED- en INA-behandelingen. Waarden met verschillende letters zijn significant verschillend.

De LED-belichting en de INA-behandelingen hadden beide een significant effect op de biomassa-vorming van de planten zoals werd vastgesteld middels drooggewichtsbepalingen (figuur 4.47). De rode LEDbelichting bleek voor een lichte toename in biomassa te zorgen. Het lichte opbrengstverlies als gevolg van de INA-behandeling dat eerder al bij tomaat naar voren kwam, werd ook bij de drie siergewassen vastgesteld.

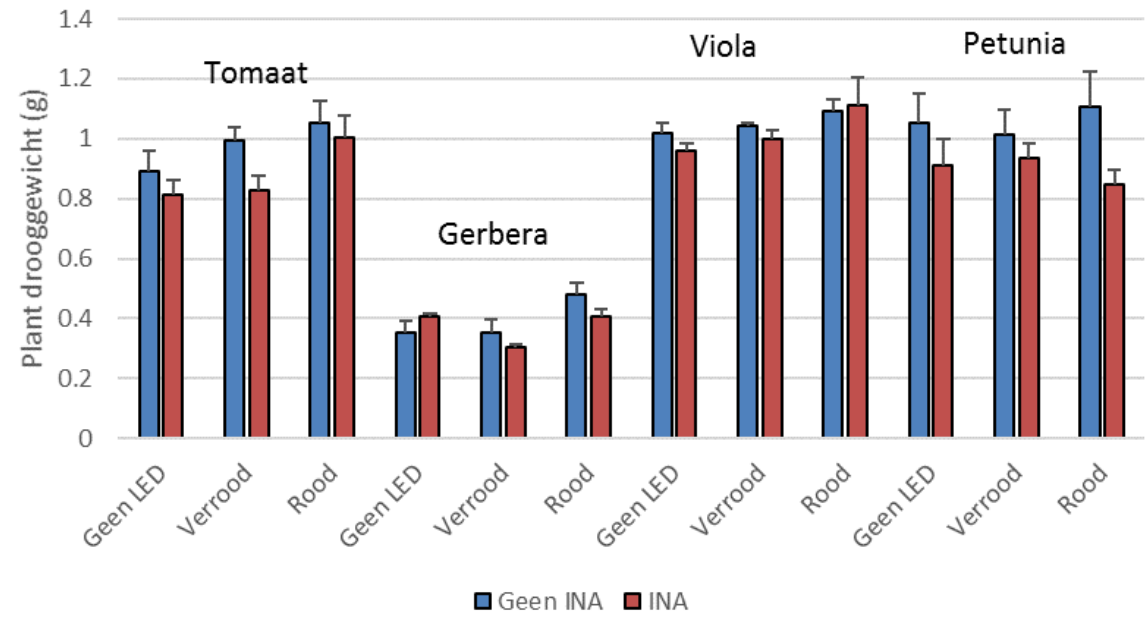

Figuur 4.47 Plantdrooggewichten van tomaat, gerbera, viola en petunia gevormd onder de verschillende $L E D$ - en INA-behandelingen en bepaald na afloop van het experiment. De grafiek geeft gemiddelde waarden weer van 2 planten (tomaat), 20 zaailingen (gerbera), 30 zaailingen (viola) en 20 zaailingen (petunia).

De glucanase-activiteit (PR2) bleek in alle behandelingsgroepen van petunia zodanig marginaal te zijn $\left(<0.1 \mu \mathrm{mol} . \mathrm{min}^{-1} \cdot \mathrm{g}^{-1}\right)$ dat hierop geen betrouwbare conclusies gebaseerd kunnen worden. Figuur 4.48 toont de glucanase-activiteit gemeten in viola, gerbera en tomaat. De glucanase-activiteit in de INAgeïnduceerde groepen van tomaat was circa drie maal hoger dan die in viola en in gerbera. Voor alle drie de gewassen werd een significant effect van de INA-behandeling waargenomen. Bij viola en tomaat was dat effect zowel op $T=0$ (voor inoculatie) als op $T=1$ (na inoculatie) te zien, bij gerbera alleen na inoculatie $(T=1)$. Behalve een significant elicitor-effect werd bij viola ook nog een significant LED-effect waargenomen, zowel op $\mathrm{T}=0$ als op $\mathrm{T}=1$, waarbij de gemiddelde PR2-activiteit het hoogst was onder 
rood licht, en het laagste onder verrood licht. Deze resultaten wijzen er op dat ook in het siergewas viola rood licht SAR-inductie kan bevorderen, zij het dat dit slechts in geringe mate is vergeleken met het effect van chemische elicitatie door INA.
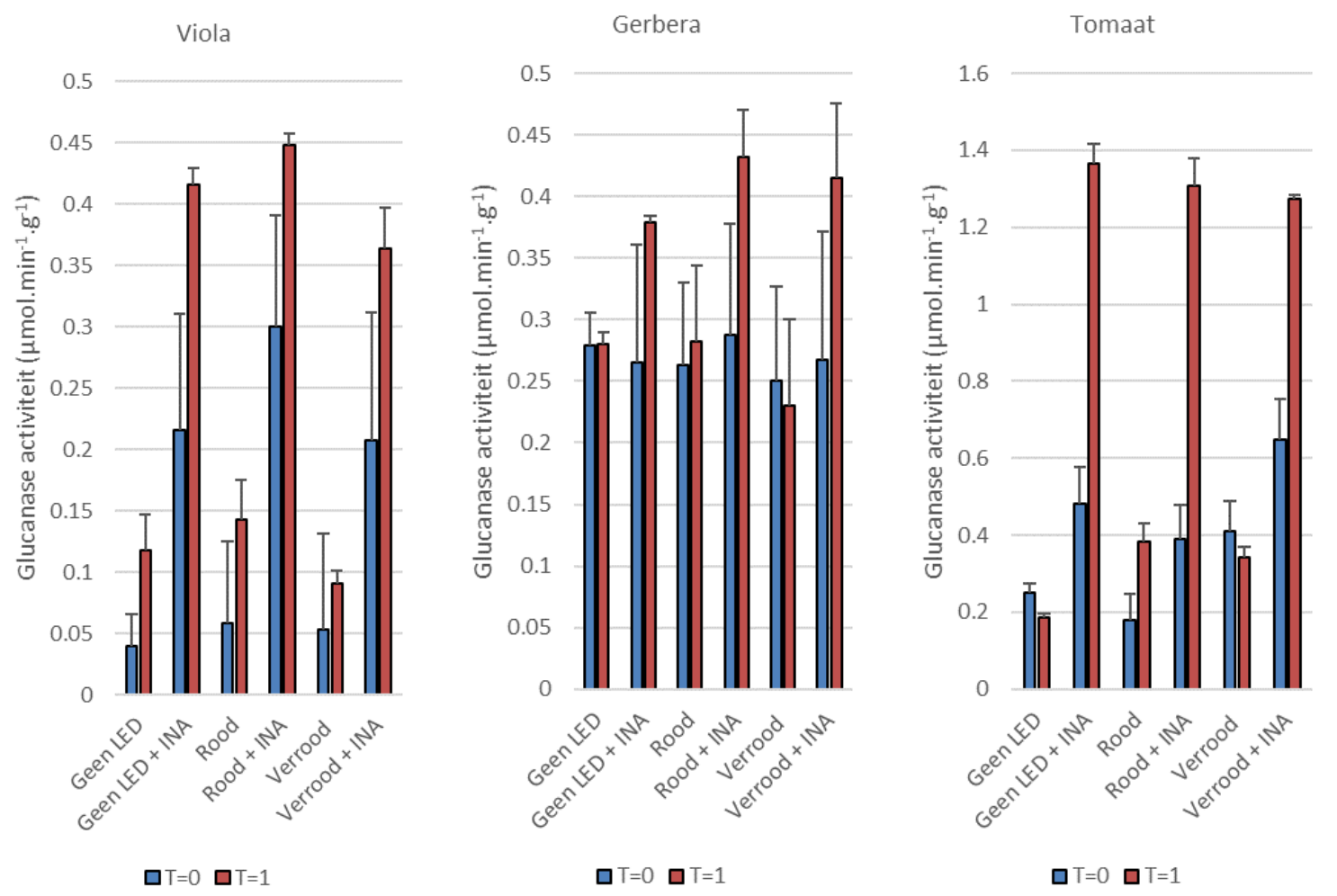

Figuur 4.48 PR2-expressie enkele uren voor $(T=0)$ en zes dagen na $(T=1)$ meeldauwinoculatie, gemeten in termen van glucanase-activiteit. $N=2$. Merk op dat de verticale schaal van de rechterfiguur (tomaat) circa drie keer groter is dan die van de beide andere figuren (viola en gerbera).

\subsection{Een eventuele rol van blauw licht}

\subsubsection{Inleiding}

In de hiervoor besproken experimenten is de mogelijke regulerende rol van rood (R) en verrood (FR) stuurlicht op de effectiviteit van elicitors voor de inductie van systemic acquired resistance (SAR) onderzocht. De resultaten sluiten aan bij literatuurgegevens die wijzen op een stimulerend effect van rood $(R)$ licht op inductie van SAR en op een rol daarbij van de rood/verrood-receptor (fytochroom) (zie hoofdstuk 2). De hier waargenomen SAR-effecten van rood stuurlicht zijn echter gering, vooral in vergelijking met de effecten die met de SAR-elicitors INA en Inssimo bereikt werden. Dit roept de vraag op welke stuurlichtcondities hier nog meer van belang kunnen zijn. In dit experiment is onderzocht of dit blauw licht is, dat gedetecteerd wordt door de groep van fotoreceptoren die bekend staan als cryptochroom.

Het fotosynthetisch apparaat van de plant absorbeert blauw (B) en rood licht (R) uit zonlicht/wit licht, waardoor in het gewas van boven naar beneden de R/FR-verhoudingen, maar ook de B/FR-verhoudingen verlaagd worden. In de donkerperiode, die normaliter ingeluid wordt met lage R/FR-verhoudingen, ontvangt het gewas uiteraard geen B, R of FR of enig ander licht. Over de relatie tussen B/cryptochroom en plantweerbaarheid is relatief weinig bekend. Wu en Yang (2010) vonden dat SAR positief gereguleerd wordt door cryptochroom 1 (CRY1). Griebel en Zeier (2008) vonden slechts een rol van fytochroom, en niet van cryptochroom bij SAR-expressie. Beide groepen deden hun experimenten met cryptochroom- 
gemankeerde Arabidopsis, maar onder verschillende daglengtes: Griebel en Zeier (2008) deden hun proeven met korte dag, terwijl Wu en Yang (2010) continue belichting toepasten. Deze laatsten speculeren, kort gezegd, dat de eersten daardoor de rol van cryptochroom bij SAR gemist hebben (Wu en Yang, 2010).

Wu en Yang (2010) presenteren een mogelijk mechanisme waarmee cryptochroom een regulerende rol zou kunnen spelen bij SAR. Centraal hierin staat COP1, een downstream component in de CRY1 signaaltransductieketen. COP1 ("Constitutive Photomorphogenic 1") faciliteert de afbraak van met name transcriptie-activatoren die fotomorfogenese en bloei reguleren (zie voor een review over COP1: Huang et al, 2014). De waarneming dat de expressie van pathogenesis related protein 1 (PR-1) en andere weerbaarheidsgerelateerde genen verhoogd zijn in cop-mutanten (Mayer et al, 1996) vormt echter een aanwijzing dat COP1 behalve fotomorfogenese ook SAR reguleert (door deze processen te onderdrukken). De activiteit van COP1 hangt af van haar subcellulaire translocatie, en van complexvorming met andere eiwitten, processen die beide onder controle lijken te staan van cryptochroom en fytochroom (Wei en Deng, 1996; Huang et al, 2014). De hypothese luidt samengevat dat blauw licht CRY1 aanzet tot afremming van de activiteit van de veronderstelde PR-onderdrukker COP1, met als resultaat dat SAR beter tot expressie komt.

In onze praktijkdoelstelling past geen continue belichting (geen 24 uur PAR per etmaal). Met het aflopen van de dagperiode loopt ook de mogelijkheid van de hierboven veronderstelde CRY1-controle van COP1 af. Het ligt daarom voor de hand om te onderzoeken of toediening van blauw stuurlicht in de donkerperiode de expressie van SAR doet verhogen, al dan niet in combinatie met rood stuurlicht en voorbehandeling met elicitor.

In dit experiment werden zaailingen van tomaat, gerbera en viola blootgesteld aan een dagperiode van 15 uur onder normale opkweekcondities in de kas. Daarbij werden groepen van deze plantjes tevens 24 uur per etmaal, dus continue blootgesteld aan blauw stuurlicht (400-500 nm; ca $5 \mu \mathrm{mol} . \mathrm{m}-2 . \mathrm{s}-1)$ en aan combinaties van blauw en rood stuurlicht. Controle-groepen ontvingen continue geen stuurlicht, of rood stuurlicht, of blauw met verrood stuurlicht, of uitsluitend verrood stuurlicht.

\subsubsection{Uitvoering van het experiment}

Het experiment vond in de periode november-december 2017 plaats in een kascompartiment van Florensis BV te Hendrik Ido Ambacht. Het werd in 2-voud uitgevoerd door het onmiddellijk na de eerste uitvoering te herhalen. De proefopstelling omvatte 6 ruime veldjes ( $\mathrm{At} / \mathrm{m} \mathrm{F}$; ca $5 \times 5 \mathrm{~m}$ ) die naast elkaar tegen de achterwand van een kascompartiment lagen en van elkaar gescheiden waren met lichtdicht folie. Het stuurlicht werd toegediend middels LED-lampen die exact midden boven elk te behandelen veldje hingen. De behandelingen bestonden uit (combinaties van) blauw (B), verrood (FR), rood (R), en geen (C) stuurlicht, zoals aangegeven in tabel 4.1. De LED-behandelingen beliepen 24 uur per etmaal (continue LED-belichting). Tevens stonden alle planten gedurende de proef bloot aan (a) normaal daglicht, en (b) standaard aanvullende groeibelichting (SON-T; 14 uur lichtperiode, start 5:30 uur, einde 16:30 uur; 42. $\mu \mathrm{mol} . \mathrm{m}-2 . \mathrm{s}-1$ ).

Tabel 4.1 De verschillende LED-behandelingen, continue toegepast (24 uur per etmaal).

\begin{tabular}{|c|c|c|c|c|}
\hline \multirow{2}{*}{ Veld } & \multirow{2}{*}{ Code } & \multicolumn{3}{|c|}{ LED-behandeling } \\
\cline { 3 - 5 } & & Blauw (B) & Ver rood (FR) & Rood (R) \\
\hline A & FR & - & $50 \mu \mathrm{mol} . \mathrm{m}^{-2} \cdot \mathrm{s}^{-1}$ & - \\
\hline B & B $+\mathrm{R}$ & $5 \mu \mathrm{mol} . \mathrm{m}^{-2} \cdot \mathrm{s}^{-1}$ & - & $5 \mu \mathrm{mol} . \mathrm{m}^{-2} \cdot \mathrm{s}^{-1}$ \\
\hline C & B & $5 \mu \mathrm{mol} . \mathrm{m}^{-2} \cdot \mathrm{s}^{-1}$ & - & - \\
\hline D & B $+\mathrm{FR}$ & $5 \mu \mathrm{mol} . \mathrm{m}^{-2} \cdot \mathrm{s}^{-1}$ & $50 \mu \mathrm{mol} . \mathrm{m}^{-2} \cdot \mathrm{s}^{-1}$ & - \\
\hline E & R & - & - & $5 \mu \mathrm{mol} . \mathrm{m}^{-2} \cdot \mathrm{s}^{-1}$ \\
\hline F & C & - & - & - \\
\hline
\end{tabular}

Bij de start van het experiment werden midden op elk veldje jonge in potgrond opgepotte tomatenplantjes (ca 3 weken oud), trays met gerbera plantjes in potgrond en trays met viola zaailingen 
in potgrond geplaatst (zie voor een impressie van een proefveldje de foto in figuur 6.1). Bevochtiging van de plantjes gebeurde door begieting met water. Figuur 4.49 toont schematisch de opzet en het verloop van het experiment. Vier dagen na de start van het experiment werd van elk gewas de helft van de planten middels bladbespuiting behandeld met de elicitor INA ( $1 \mathrm{mM}$ ); bij de tomatenplanten gebeurde dit aan de onderste twee echte bladeren, bij gerbera en viola werd per veldje een hele tray homogeen beneveld. Drie dagen na elicitor-toediening $(T=0)$ werd in de ochtend van elke groep planten bladmateriaal geoogst en direct ingevroren (mengmonsters van 6 tomatenplanten, en mengmonsters van random posities uit de viola en gerbera trays). Het geoogste bladmateriaal werd op droog ijs in bevroren toestand naar de WUR-locatie te Bleiswijk vervoerd, en daar opgeslagen bij $-80{ }^{\circ} \mathrm{C}$. In de middag van dezelfde dag $(T=0)$ werden de tomaten en gerbera planten middels verneveling van een homogene suspensie van echte meeldauw condiën geïnoculeerd (inoculum concentratie ca. $10^{5} \mathrm{cfu} / \mathrm{ml}$ ); de suspensies werden ter plaatse vers bereid uit sporulerend mycelium vanaf geïnfecteerd tomatenrespectievelijk gerbera-blad. Voor viola waren geen meeldauw conidiën beschikbaar en daarom werden deze plantjes "geïnoculeerd" middels een bespuiting met $0.5 \mathrm{mM}$ salicylzuur. Om de voor inoculatie benodigde hoge luchtvochtigheid te verwezenlijken werd elk veldje met water bevochtigd en gedurende circa de eerste 20 uur na toediening van het inoculum afgedekt met lichtdoorlatend folie. Zeven dagen na inoculatie $(T=1)$ werd in de ochtend de tweede bladoogst uitgevoerd, op identieke wijze als de eerste. Het geoogste bladmateriaal werd opgeslagen bij -80 oC. Direct na de tweede bladoogst $(T=1)$ werden de tomaten- en gerberaplanten overgebracht naar een kascompartiment van WUR in Bleiswijk waar het inoculum onder standaard daglichtcondities (geen stuurlicht) tot sporulerend mycelium kon uitgroeien. Twee weken na inoculatie werd de mate van meeldauwaantasting bij tomaat beoordeeld door het aantal meeldauwvlekken op het $3^{\text {de }}$ samenstelde blad (geteld vanaf de cotylen) te tellen; tevens werd van elk van deze bladeren het bladoppervlakte opgemeten. In het eerste experiment werd dit gedaan bij 8 planten, in het tweede experiment bij 16 planten. Vier weken na inoculatie werd de meeldauwschade bij gerbera beoordeeld.
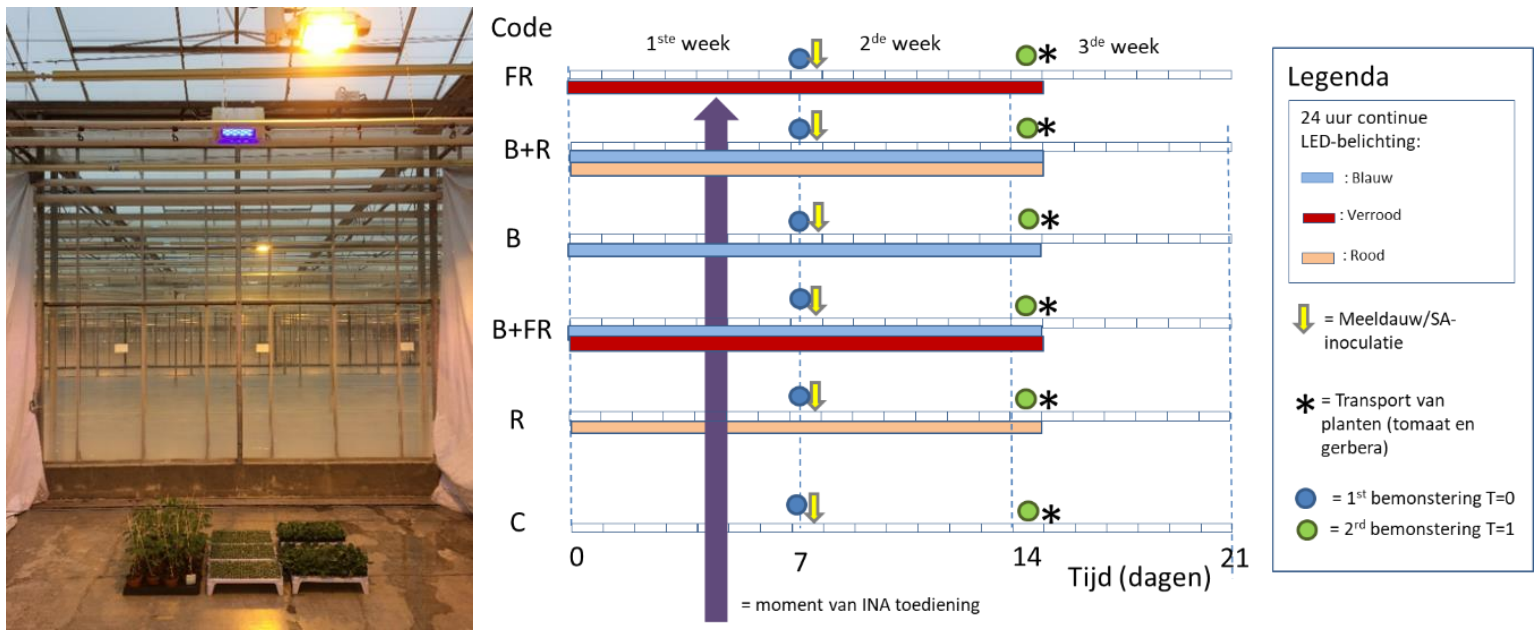

Figuur 4.49 Foto: Impressie van een proefveldje met van links naar rechts tomatenplanten, viola, en gerbera. Rechterfiguur: schematische weergave van de proefopzet en het verloop van het experiment. Aan het begin van de derde week werden de tomaten- en gerberaplanten naar een kascompartiment in Bleiswijk vervoerd waar het mycelium tot ontwikkeling kwam en de meeldauwaantasting gemeten werd.

\subsubsection{Resultaten en conclusies}

De effecten van de gecombineerde LED- en elicitor-behandelingen op de expressie van systemic acquired resistance (SAR) werden bij tomaat bepaald aan de hand van de expressie op $\mathrm{T}=0$ (vlak voorafgaande aan meeldauwinoculatie) en $T=1$ (een week na meeldauwinoculatie) van de SAR-merkers PR1 en PR2 (B1,3 -glucanase-activiteit), en bij viola en gerbera aan de hand van de expressie op $T=0$ en $T=1$ van alleen PR2 (B-1,3-glucanase-activiteit). 
De expressie van PR1 werd gemeten door de in het blad op $T=0$ en $T=1$ aanwezige hoeveelheid mRNA van PR1 te bepalen ten opzichte van de min of meer constant aanwezige hoeveelheid mRNA toebehorend aan de huishoudgenen L33 en EF1a. Met deze data werd vervolgens de toegenomen relatieve PR1expressie op $T=1$ berekend ten opzichte van de relatieve PR1-expressie op $T=0$. Figuur 4.50 toont de resultaten van de eerste tomatenproef, met in de linkerfiguur de PR1 expressie genormaliseerd met EF1a, en in de rechterfiguur de PR1 expressie genormaliseerd met L33. Deze resultaten duiden er op (1) dat PR1 nauwelijks geïnduceerd werd in de controlegroep (C) en in de groepen die continue aan rood licht blootgesteld waren ( $R$ en $B+R$ ), en (2) dat PR1 geïnduceerd werd in de groepen die continue blootgesteld waren aan verrood (FR), blauw (B), of een combinatie daarvan ( $F R+B)$. De data tonen geen consistent inducerend effect van de elicitor INA (figuur 4.50). De PR1 data van de tweede tomatenproef, weergegeven in figuur 4.51, wijken sterk af van die van de eerste proef. In nagenoeg alle groepen is er nauwelijks een toename van de PR1-expressie te zien tussen $T=0$ en $T=1$. Dit komt doordat de relatieve hoeveelheden PR1 mRNA op T=0 reeds op het niveau lagen van de relatieve hoeveelheden PR1 mRNA op $T=1$, die overigens min of meer gelijk waren aan die van $T=1$ uit de eerste proef (data hier niet getoond). Dit betekent dat de SAR-inductie in de tweede proef waarschijnlijk reeds voorafgaande aan de meeldauwinoculatie was ingetreden; de oorzaak hiervan is onbekend. Statistische evaluatie van de gemiddelden uit beide proeven is daarom achterwege gelaten.
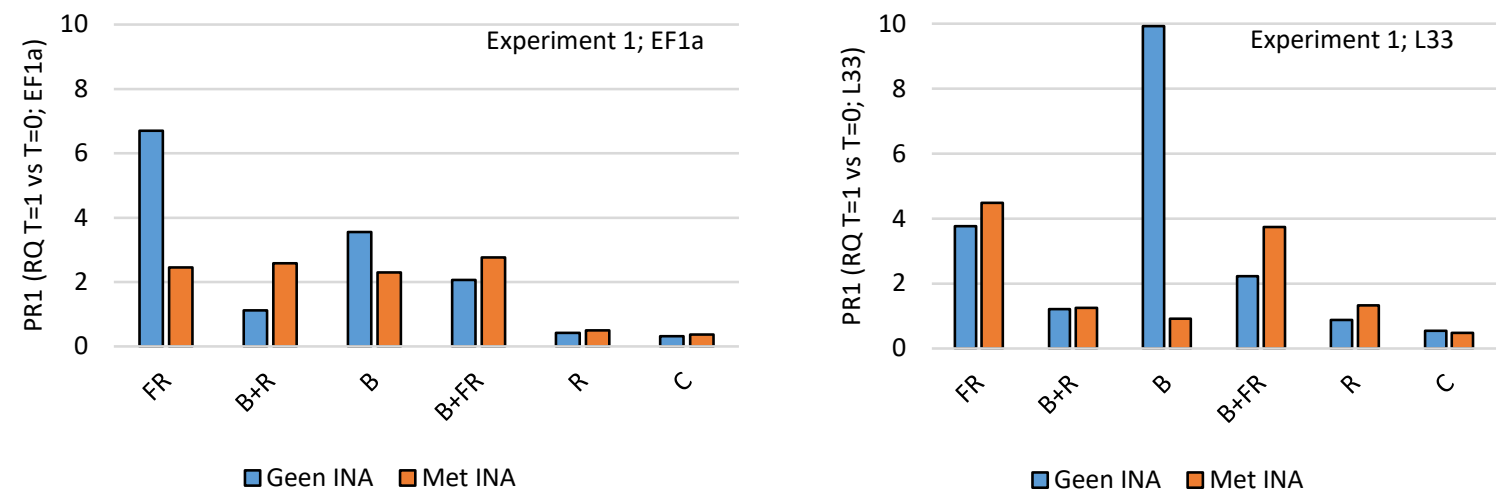

Figuur 4.50 De relatieve toename van PR1-expressie in tomaat, zonder en met INA-behandeling, in de eerste proef tussen $T=0$ (vlak voor meeldauwinoculatie) en $T=1$ (zeven dagen na meeldauwinoculatie), genormaliseerd ten opzichte van de expressie van het huishoudgen EF1a (linkerfiguur) en het huishoudgen L33 (rechterfiguur). Zie voor de codes van de LED-behandelingen tabel 4.1.
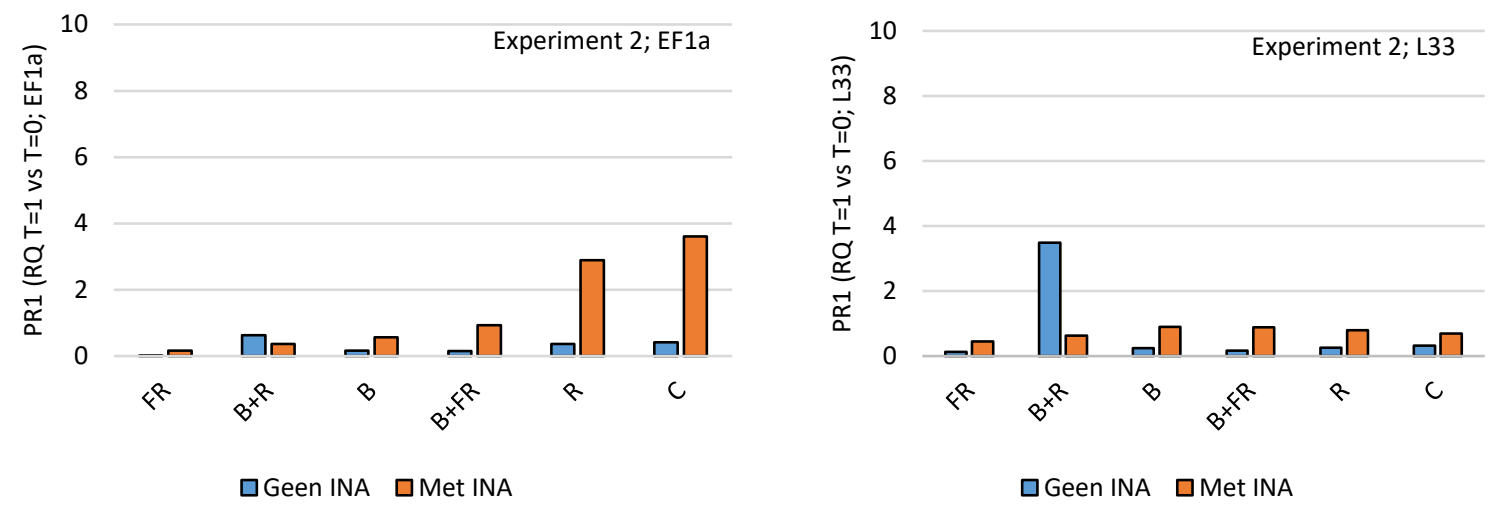

Figuur 4.51 De relatieve toename van PR1-expressie in tomaat, zonder en met INA-behandeling, in de tweede proef tussen $T=0$ (vlak voor meeldauwinoculatie) en $T=1$ (zeven dagen na meeldauwinoculatie), genormaliseerd ten opzichte van de expressie van het huishoudgen EF1a (linkerfiguur) en het huishoudgen L33 (rechterfiguur). Zie voor de codes van de LED-behandelingen tabel 4.1.

Figuur 4.52 toont de glucanase-activiteit die in de eerste (linkerfiguur) en tweede proef (rechterfiguur) in het tomatenblad op $\mathrm{T}=0$ en op $\mathrm{T}=1$ gemeten werd. Te zien is dat de glucanase expressie-niveaus in de tweede proef voorafgaande aan de meeldauwinoculatie $(T=0)$ gemiddeld in de tweede proef veel hoger liggen dan in de eerste proef, en dat ze die van de groepen die niet met INA behandeld waren zelfs overstegen. Deze waarnemingen bevestigen dat de SAR-inductie bij de tomatenplanten in de tweede 
proef waarschijnlijk reeds voorafgaande aan de meeldauwinoculatie was ingetreden. Uit deze data is geen conclusie te trekken over enig LED-effect op PR2-expressie. Wel blijkt uit deze resultaten een sterk en consistent positief effect van de elicitor op de PR2-expressie. Statistische evaluatie van de data uit beide experimenten gezamenlijk wijst op een significant INA-effect, geen significant LED-effect, en geen significante interactie tussen INA- en LED-behandeling.

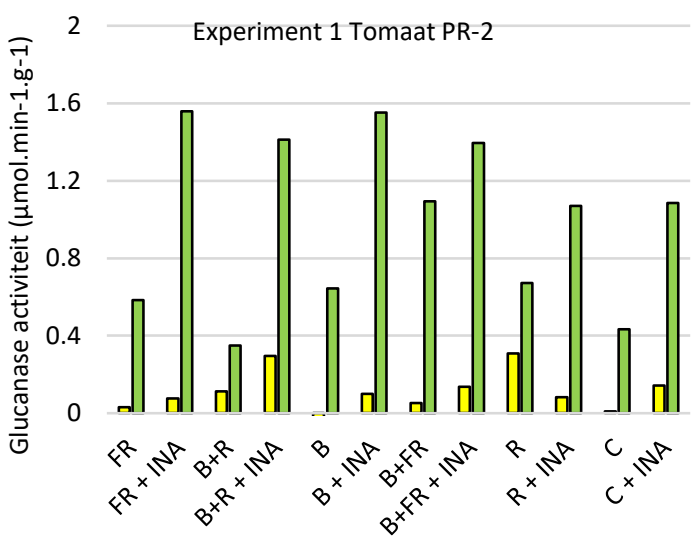

口T0 口T1

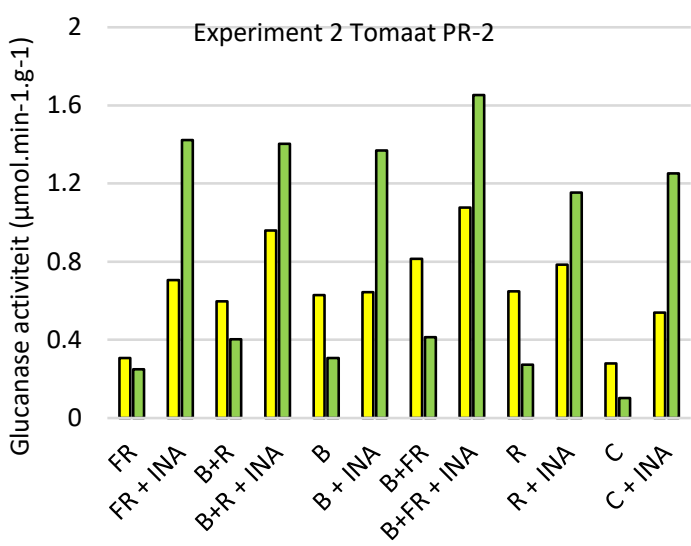

口T0 घT1

Figuur 4.52 Activiteit van B-1,3-glucanase in tomaat, zonder en met INA-behandeling, op T=0 (voor meeldauw-inoculatie) en $T=1$ (na meeldauwinoculatie) in de eerste proef (linkerfiguur) en in de tweede proef (rechterfiguur). Zie voor de codes van de LED-behandelingen tabel 6.1; "+INA" = behandeld met INA.

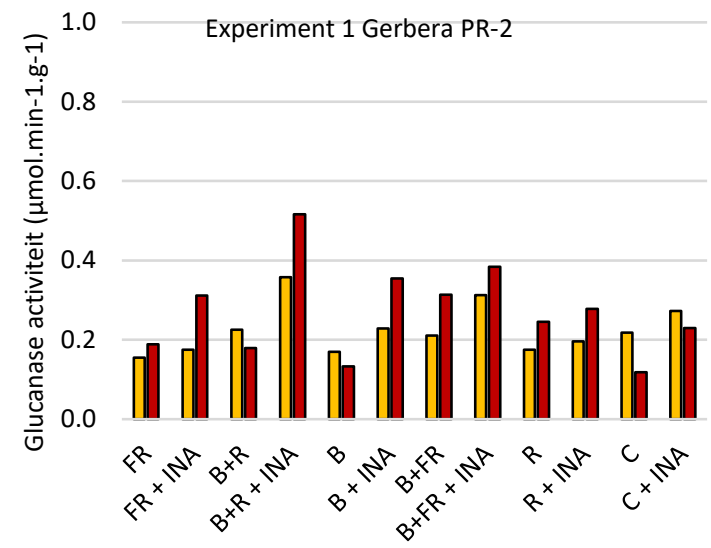

$\square \mathrm{T0} \square \mathrm{T} 1$

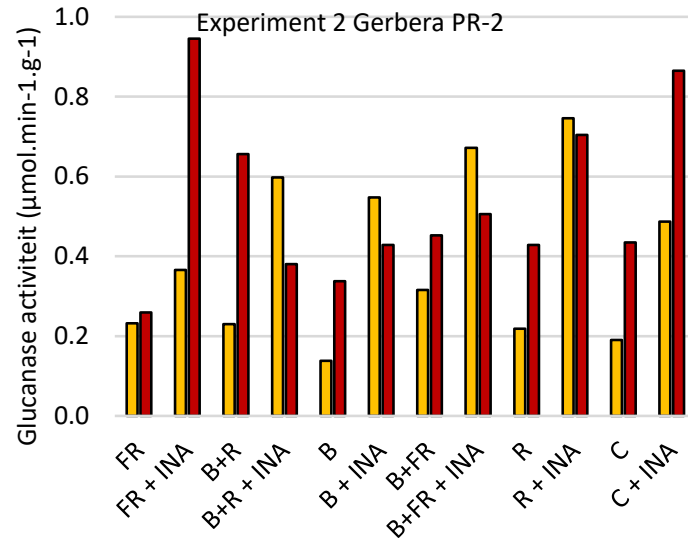

$\square \mathrm{TO} \square \mathrm{T} 1$

Figuur 4.53 Activiteit van B-1,3-glucanase in gerbera, zonder en met INA-behandeling, op $T=0$ (voor meeldauw-inoculatie) en $T=1$ (na meeldauwinoculatie) in de eerste proef (linkerfiguur) en in de tweede proef (rechterfiguur). Zie voor de codes van de LED-behandelingen tabel 6.1; "+INA" = behandeld met INA.

De glucanase-metingen in gerbera blad gaven min of meer hetzelfde beeld, zij het dat de onderlinge verschillen tussen de groepen minder groot zijn (figuur 4.53); kennelijk hebben de gerbera-planten in de tweede proef eveneens een SAR-inductie ondergaan voorafgaande aan de meeldauw-inoculatie $(T=0)$. Ook bij gerbera blijkt INA effectief geweest als primer van SAR. De data laten geen conclusie toe over enig LED-effect. 


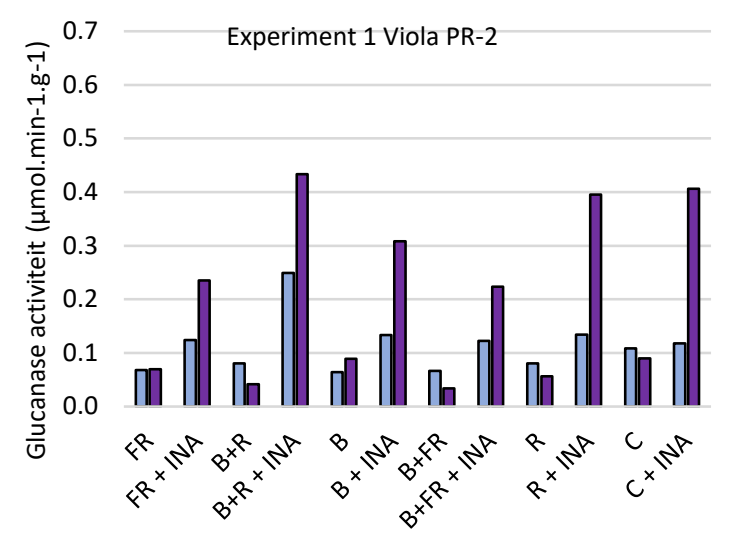

口T0 घT1

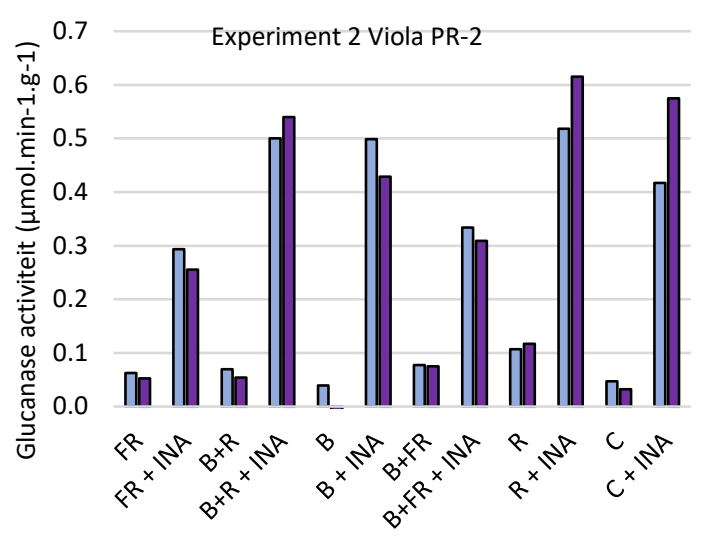

口T0 घT1

Figuur 4.54 Activiteit van B-1,3-glucanase in viola, zonder en met INA-behandeling, op $T=0$ (voor meeldauw-inoculatie) en $T=1$ (na meeldauwinoculatie) in de eerste proef (linkerfiguur) en in de tweede proef (rechterfiguur). Zie voor de codes van de LED-behandelingen tabel 6.1; "+INA" = behandeld met INA.

Voor het oproepen van de SAR-respons werd bij viola geen meeldauw-inoculum gebruikt, maar een bespuiting met salicylzuur. Voor de viola-groepen die met INA behandeld waren, lijkt deze alternatieve inoculatie in de eerste proef gewerkt te hebben, want de glucanase-activiteit was in al die groepen hoger op $T=1$ dan op $T=0$ (zie de linkerfiguur van figuur 4.54). In de tweede proef werden echter geen duidelijke verschillen in PR2-expressie waargenomen tussen de monsters van T=0 en $T=1$ omdat ook hier weer relatief hoge glucanase-activiteit tot expressie kwam op $\mathrm{T}=0$ (figuur 4.54., rechterfiguur). Ook bij viola lijkt dus in de tweede proef al inductie van SAR plaats gevonden te hebben voorafgaande aan $T=0$. En ook blijkt bij viola zowel in de eerste als tweede proef dat INA effectief was als primer van SAR. Er werd geen significant LED-effect bij Viola vastgesteld.

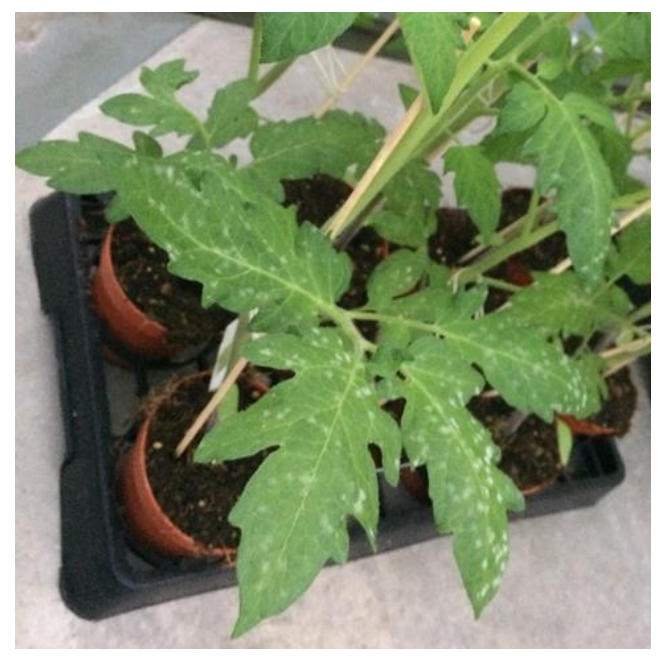

Figuur 4.55 Mycelium van echte meeldauw op tomaat, twee weken na inoculatie.

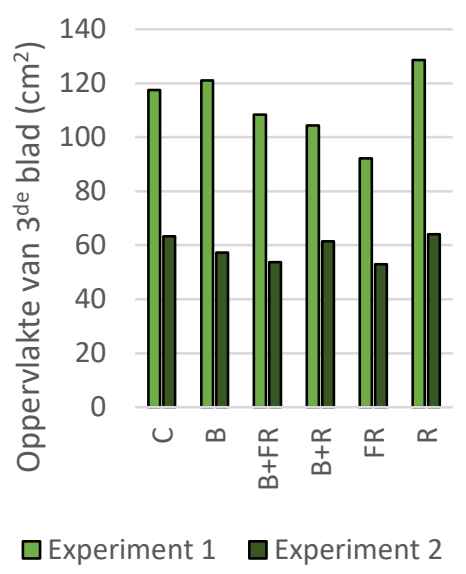

Figur 4.56 Gemiddelde bladoppervlakten in het eerste en het tweede experiment van de groepen die de verschillende $L E D$-regimes ondergaan hadden

Twee weken na meeldauw-inoculatie vertoonden de tomatenplanten min of meer uniforme, van elkaar te onderscheiden myceliumvlekjes (figuur 4.55). Bij elke individuele plant werd het aantal vlekjes bepaald dat aanwezig was op het $3^{\text {de }}$ samengestelde blad (geteld vanaf de cotylen) en werd de oppervlakte van dat blad opgemeten. Figuur 4.56 laat zien dat de gemiddelde oppervlakte van dit $3^{\text {de }}$ samengestelde blad in het eerste experiment ongeacht de LED-behandeling substantieel groter was dan in het tweede experiment. Het aantal meeldauwvlekken op dit $3^{\text {de }}$ blad was in het tweede experiment echter hoger dan in het eerste experiment (vergelijk de linkergrafieken uit figuur 4.57 en 4.58). Door van elk individueel $3^{\text {de }}$ blad het aantal vlekjes te delen door de bladoppervlakte werd de 
dichtheid van meeldauwvlekjes verkregen; deze zijn voor beide experimenten weergegeven in de rechtergrafieken van figuren 4.57 en 4.58. Statistische analyse van de data toont tussen beide experimenten onzekerheidsverschillen omtrent LED- en INA-effect. In het eerste experiment was een significant INA-effect aanwezig (Fpr=0.006), maar geen LED-effect $(F p r=0.132)$ ten aanzien van de meeldauwdichtheden: behalve in de groepen die verrood LED-licht ontvingen, had INA in alle overige groepen een meeldauwonderdrukkend effect (figuur 4.57). In het tweede experiment was geen significant INA-effect aanwezig (Fpr=0.52), maar wel een significant LED-effect ( Fpr=0.005), en een significante interactie tussen INA- en LED-behandeling ( $F p r=0.037)$ : alle groepen op één na die niet met INA behandeld waren, vertoonden een significant hogere meeldauwdichtheid dan de groep die aan blauw LED-licht had blootgestaan (figuur 4.58). Figuur 6.11 toont de gemiddelde meeldauwdichtheden berekend met de data van beide experimenten tezamen; hier is sprake van een significant LED-effect, een significante interactie tussen INA- en LED-behandeling ( $F p r=0.003$, respectievelijk 0.021), maar net geen significant INA-effect $(\mathrm{Fpr}=0.059)$.
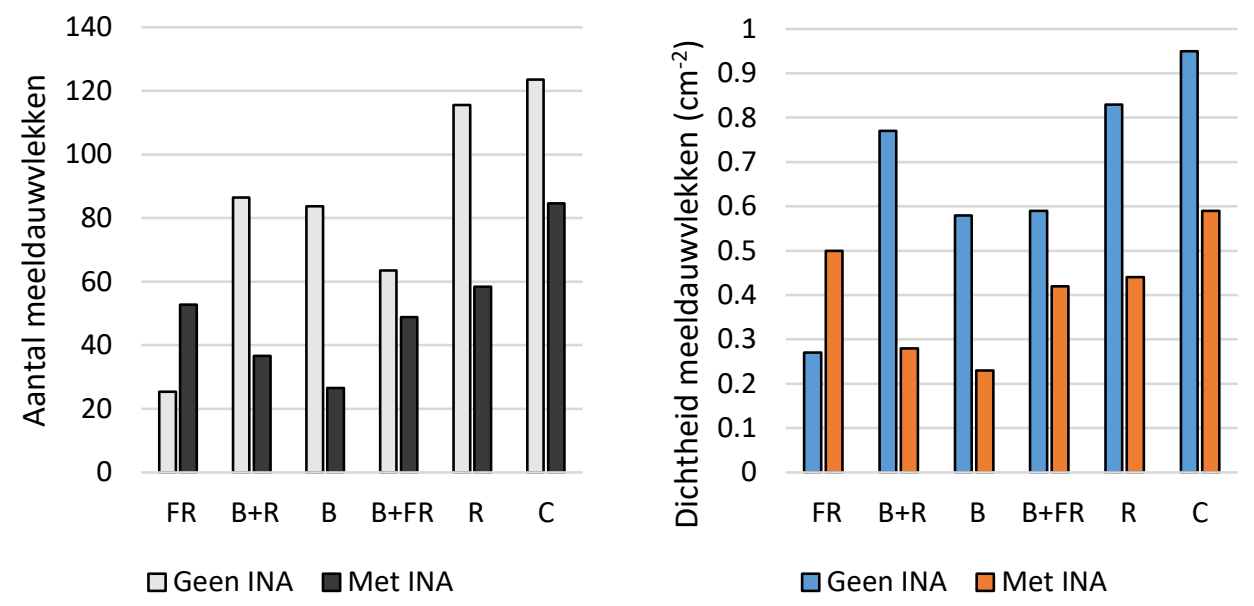

Figuur 4.57 Meeldauwaantasting van het $3^{\text {de }}$ blad (geteld vanaf de cotylen) van de tomatenplanten in experiment 1, uitgedrukt in het gemiddeld aantal meeldauwvlekken op het blad (links; Isd=67) en uitgedrukt in de gemiddelde dichtheid van de meeldauwvlekken op het blad (rechts; Isd=0.44). $n=8$. Zie voor de codes van de $L E D$-behandelingen tabel 4.1 .
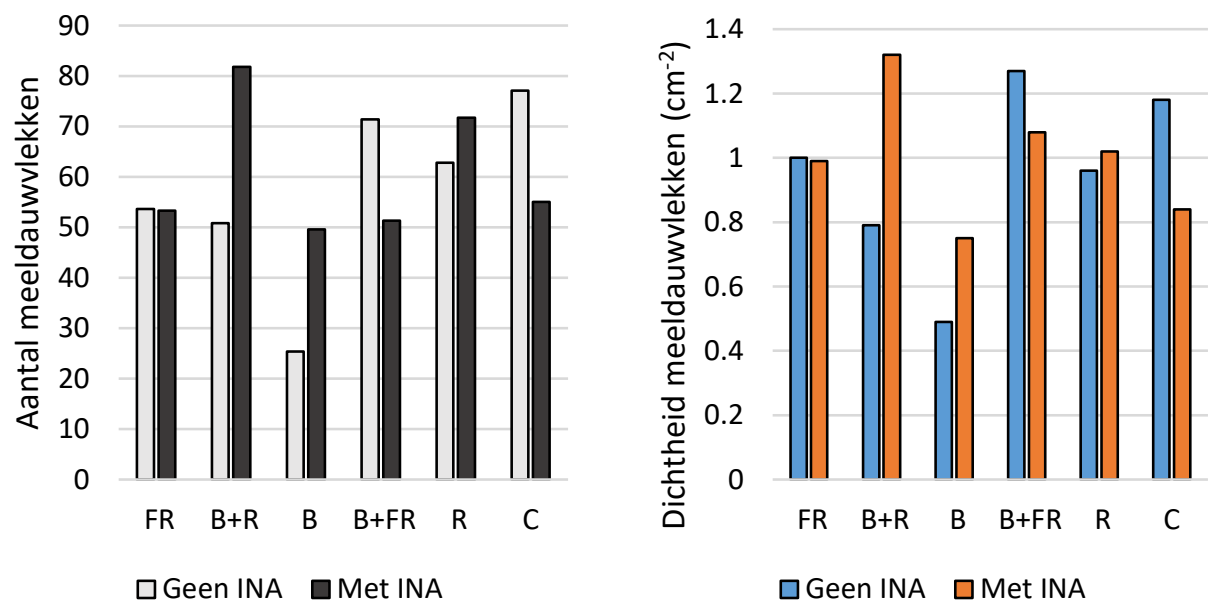

Figuur 4.58 Meeldauwaantasting van het $3^{\text {de }}$ blad (geteld vanaf de cotylen) van de tomatenplanten in experiment 2, uitgedrukt in het gemiddeld aantal meeldauwvlekken op het blad (links; Isd=29) en uitgedrukt in de gemiddelde dichtheid van de meeldauwvlekken op het blad (rechts; Isd=0.40). $n=16$. Zie voor de codes van de LED-behandelingen tabel 4.1.

De meeldauwontwikkeling in de gerberaplanten was veel trager dan die in de tomatenplanten. Ongeveer een maand na inoculatie werd meeldauwmycelium op het geberablad waargenomen. Deze planten bleken echter ook ernstige Botrytis-schade te vertonen. Omdat dit het trekken van betrouwbare conclusies omtrent behandelingseffecten op echte meeldauw verhinderd, worden deze waarnemingen hier verder buiten beschouwing gelaten. 


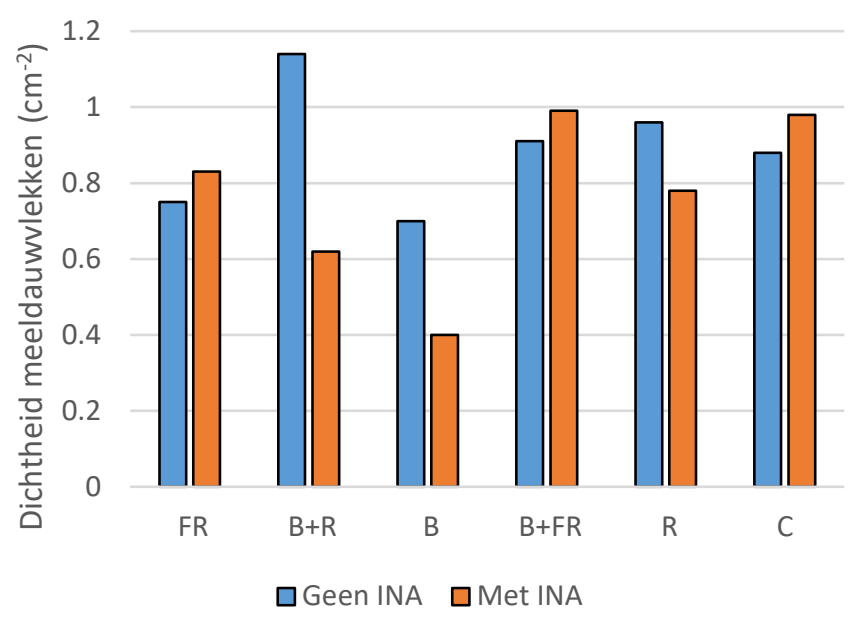

Figuur 4.59 Meeldauwaantasting van het $3^{\text {de }}$ blad (geteld vanaf de cotylen) van de tomatenplanten uitgedrukt in de gemiddelde dichtheid van de meeldauwvlekken op het blad berekend met de gezamenlijke data uit experiment $1(n=8)$ en $2(n=16)$. Lsd=0.30. Zie voor de codes van de LED-behandelingen tabel 4.1.

In dit experiment is onderzocht of toepassing van blauw stuurlicht een mogelijke rol zou kunnen spelen bij de inductie van SAR. Op basis van literatuurgegevens werd ingeschat dat een dergelijk effect het sterkst naar voren zou komen bij continue LED-stuurlicht (zie hoofdstuk 4.6.1). In tegenstelling tot de hiervoor beschreven experimenten werd in dit experiment daarom continue LEDstuurlicht (24 uur per etmaal) toegepast. Het experiment werd in tweevoud uitgevoerd door het onmiddellijk te herhalen. De resultaten laten zien dat bij de herhaling bij alle drie de gewassen een gelijksoortige verstoring was opgetreden, omdat ze alle drie een sterke inductie van SAR-merkers lieten zien voorafgaande aan de inoculatie met meeldauw. Wellicht hebben de planten in het tweede experiment tussentijds blootgestaan aan een onbekende stress-factor. De onzekerheid over de verkregen data maakt het lastig om algemene conclusies te trekken. De resultaten bevestigen in ieder geval de effectiviteit van INA ten aanzien van inductie van SAR(-merkers) en meeldauwonderdrukking. Verder lijkt blauw stuurlicht onder de toegepaste condities nauwelijks bij te dragen aan SAR-inductie, maar wel onderdrukking van meeldauw te bevorderen. Het verdient daarom aanbeveling om nader te onderzoeken of blauw stuurlicht wellicht direct inwerkt op het infectieproces en op de ontwikkeling van de schimmel. 


\section{$5 \quad$ Conclusie}

De centrale onderzoeksvraag van dit project was of de effectiviteit van chemische elicitors beïnvloed kan worden met rood en verrood stuurlicht, en zo ja, of dit fenomeen in de praktijk benut kan worden voor geïntegreerde bestrijding (IPM). Om hier enig inzicht in te verkrijgen werd een reeks van min of meer uniforme kasexperimenten uitgevoerd met groepen van jonge tomatenplanten als modelgewas, aangevuld met gerbera en enkele perkplanten. Het beoogde weerbaarheidseffect beperkte zich tot systemic acquired resistance (SAR), een universeel weerbaarheidssysteem dat met name bescherming biedt tegen biotrofe schimmels. In dit geval is gewerkt met echte meeldauw.

Het complexe systeem van een opgroeiend gewas dat geprimed wordt met een elicitor en dat besmet raakt met een pathogeen omvat diverse processen, die mogelijk elk op hun eigen wijze invloed ondergaan van het toe te passen stuurlicht, en in theorie onder hetzelfde stuurlicht een tegengesteld eindresultaat kunnen bevorderen. Zo zou een bepaalde kwaliteit stuurlicht bijvoorbeeld de plantweerbaarheid kunnen stimuleren, maar ook de virulentie van het pathogeen kunnen begunstigen, met nul effect als netto eindresultaat. Daarom is gekozen voor een proefopzet waarbij stuurlicht toegediend kon worden tijdens de verschillende procesfasen: de fase waarin mogelijk de receptiviteit voor de elicitor beïnvloed wordt, de fase tussen priming en inoculatie met het pathogeen, en de fase waarin plant en pathogeen interactie met elkaar hebben. Om onderscheid te kunnen maken tussen enerzijds de inductie van SAR, en anderzijds de onderdrukking van het pathogeen, werden zowel de expressie van SAR-merkers, als de meeldauwschade opgemeten.

Hoewel het hier om onderzoek met een fundamenteel karakter gaat, zijn de experimenten met het oog op het eventuele praktijkbelang zo veel mogelijk onder praktijkcondities uitgevoerd: in een kascompartiment onder daglicht, eventueel bijbelicht met SON-T, met normale dag- en nachtperiodes. Hieruit vloeide praktisch voort dat de stuurlichttoediening steeds in de eerste uren van de donkerperiode viel, soms al beginnend in de dagperiode, en soms continue doorlopend in de nacht. De rood- en verrood-LED-doseringen waren in alle experimenten respectievelijk $5 \mu \mathrm{mol} . \mathrm{m}-2 . \mathrm{s}-1$ en 50 $\mu \mathrm{mol} . \mathrm{m}-2 . \mathrm{s}-1$ en leidde tot een meetbaar fytochroomeffect op de strekking van de planten.

De experimenten lieten zien dat priming middels toediening van elicitors tot een significante (verhoogde) expressie van SAR(-merkers) leidde. Werkzaam waren Inssimo en 2,6dichloroisonicotinezuur (INA). Althans in de hier gebruikte doseringen en onder de hier toegepaste condities bleken probenazole, B-aminoboterzuur (BABA), salicylzuur, en Hicure niet effectief voor SARinductie. De experimenten lieten tevens zien dat SAR-inductie niet altijd gepaard gaat met (gedeeltelijke) onderdrukking van de meeldauwontwikkeling. Behalve SAR-expressie spelen ook andere factoren een belangrijke rol voor meeldauwinfectie en -ontwikkeling, zoals de relatieve luchtvochtigheid in het gewas, en de beschikbaarheid van nutriënten voor het pathogeen. SARinductie is dus geen absolute garantie voor een betere bescherming tegen het pathogeen. Dat er geen effect van stuurlicht toegediend na inoculatie werd waargenomen, suggereert dat althans de meeldauwontwikkeling op zichzelf ongevoelig is voor het toegediende rode/verrode stuurlicht.

Salicylzuur (SA) fungeert lokaal in de plant als hormoon in de SAR-regulatie (SA is géén systemisch signaalmolecuul). Op basis van eerder onderzoek werd verondersteld dat SAR-inductie gepaard gaat met verhoogde concentraties SA. In dit project kon dit niet bevestigd worden en werden uitsluitend relatief lage SA-concentraties gemeten (vrij en geconjugeerd). Een verklaring hiervoor is niet gevonden. Een op basis van literatuurgegevens veronderstelde rol van de hoeveelheid fotosynthetisch actieve straling (PAR) kon niet worden aangetoond. Mogelijk wordt SAR niet slechts door SA-gehaltes maar ook in belangrijke mate door de gehaltes of receptiviteit van SA-receptoren gereguleerd, of vindt modulatie van het SAR-signaal downstream van SA plaats. Waargenomen werd dat planten blootgesteld aan relatief lagere PAR-niveaus weliswaar een sterkere SAR-respons vertoonden, maar niettemin een significant hogere meeldauwdichtheid op het blad ontwikkelden. Kennelijk hadden hier andere factoren dan SAR-expressie de overhand.

De resultaten lieten een significant stuurlicht-effect zien op de expressie van SAR(-merkers), waarbij rood stuurlicht (hoge R/FR-verhouding) in vergelijking tot verrood stuurlicht en geen stuurlicht een stimulerend effect had op SAR-expressie. Deze waarneming sluit aan bij de in de literatuur gerapporteerde rol van fytochroom bij SAR. Tevens werd waargenomen dat dit stuurlicht-effect onder 
de hier toegepaste condities bewerkstelligd werd in de fase voorafgaande aan de meeldauwinoculatie. Daarbij correleerde toepassing van stuurlicht vóór inoculatie in de volgorde van verrood stuurlicht geen stuurlicht - rood stuurlicht positief met onderdrukking van meeldauw. Deze stuurlicht-effecten op SAR-expressie en meeldauwontwikkeling zijn echter aanzienlijk geringer dan de effecten bewerkstelligd door de elicitors INA en Inssimo. Er werd geen consistente interactie of synergistisch effect van het stuurlicht en de elicitors aangetoond; de effecten lijken additief te zijn.

De experimenten met gerbera, petunia en viola lieten zien dat althans gerbera en viola kwalitatief dezelfde SAR-expressie vertoonden in reactie op de stuurlicht- en elicitor-behandelingen. Dit past bij de algemeen geaccepteerde aanname dat SAR en SAR-regulatie binnen het plantenrijk een tamelijk universeel weerbaarheidssysteem is. De bevindingen voor tomaat lijken dus ook relevant te zijn voor sierteeltgewassen.

In dit onderzoek is met het doel kennis over het mechanisme te verwerven onderscheid gemaakt tussen de chronologische procesfasen. In de praktijksituatie, bij een voortdurende ziektedruk, zullen deze fasen in het gewas tegelijkertijd lopen. Het middels stuurlicht beïnvloeden van de verschillende fasen afzonderlijk zal dus in de praktijk niet mogelijk zijn. De resultaten wijzen er op dat dit geen probleem hoeft te zijn: rood stuurlicht (hoge R/FR-verhoudingen) effectief voor SAR-inductie en meeldauwonderdrukking in de ene fase, bleek voor beiden niet antagonistisch in de andere fase.

In onze experimenten bleken de effectieve elicitors consequent in staat SAR inductie te bevorderen. Niet in alle gevallen ging dit gepaard met meeldauwonderdrukking. Niettemin is het gebruik van elicitors voor IPM in de praktijk wel degelijk interessant omdat de meeldauwonderdrukking die hiermee bereikt kan worden substantieel bleek. Die conclusie geldt echter niet voor de bijdrage die stuurlicht in onze experimenten leverde: er werd weliswaar onder invloed van rood stuurlicht SARinductie waargenomen en soms ook onderdrukking van meeldauwschade, maar die effecten waren relatief gering. Anderzijds betekent dit dat toepassing van rood of verrood stuurlicht voor geheel andere doeleinden dan weerbaarheidsinductie in de praktijk geen serieuze negatieve consequenties zal hebben voor de effectiviteit van eventueel gelijktijdig tegen meeldauw toe te passen elicitors.

Opgemerkt zij dat bovenstaande conclusies betrekking hebben op SAR en echte meeldauw; hoe andere weerbaarheidssystemen, geprimed met andere effectieve elicitors, en gericht tegen andere typen van pathogenen en plagen onder de hier aangelegde condities reageren, is in dit project niet onderzocht. 


\section{Chemische en moleculaire analyse- protocollen}

\subsection{Bladmonstername en monstervoorbewerking}

Ten behoeve van salicylzuur- en jasmonzuur-bepalingen, en de analyses waarin de expressie van PR1 en PR2 gevolgd werd, werden bladmonsters genomen. In de experimenten met het modelgewas tomaat werden hiertoe steeds boven in meerdere planten per monster uniform uit de eerste, volledig ontvouwen samengestelde bladeren blaadjes genomen en samengevoegd tot monsters van circa 3 gram. Bemonstering van de overige gewassen geschiedde door at random blad(delen) weg te knippen van meerdere planten per monster. De monsters werden onmiddellijk ingevroren in vloeibare stikstof en bewaard bij $-80^{\circ} \mathrm{C}$ tot aan de verwerking voor analyse van PR1, PR2 en salicylzuur. Om de monsters geschikt te maken voor efficiënte extractie werden ze in bevroren toestand met een diepgevroren vijzel en mortier tot een zeer fijn poeder fijngemalen, en in de juiste porties afgewogen.

\subsection{Glucanase-assay}

De gebruikte assay ter bepaling van $\beta$-1,3-glucanase activiteit in enzympreparaten van vers bevroren en fijngemalen bladmateriaal is een stopped colorimetrische assay met het natuurlijke polysaccharide laminarine uit Laminaria digitata (Sigma L9634) als substraat. Hydrolyse van de $\beta-1,3-$ glucaanverbindingen tussen de suikereenheden van laminarine resulteert in de vorming van reducerende suikermonomeren en -oligomeren. Deze reducerende suikers werden gekwantificeerd na reactie met een reagens van dinitrosalicylic acid (DNSA-reagens: 1 gram 3,5-dinitrosalicylzuur in 20 $\mathrm{ml} 2 \mathrm{~N} \mathrm{NaOH}$ en $20 \mathrm{~g}$ sodium potassium tartrate tetrahydrate aangevuld met water tot $100 \mathrm{ml}$; Miller, 1959), wat resulteert in een product dat gedetecteerd kan worden bij $540 \mathrm{~nm}$. De enzymactiviteit wordt uitgedrukt in het aantal molen reducerende suikers gevormd per minuut per hoeveelheid versgewicht plantmateriaal. Om de absorptie om te kunnen rekenen naar hoeveelheden geproduceerde reducerende suikers werd een ijklijn gemaakt met glucose.

Bereiding van enzympreparaat uit vers bevroren bladmateriaal: aan $0.50 \mathrm{~g}$ bevroren en fijngemalen bladmateriaal werd $5 \mathrm{ml}$ extractiebuffer toegevoegd $(50 \mathrm{mM}$ sodium acetate buffer $\mathrm{pH} 5.5$ inclusief 10 $\mathrm{mM}$ sodium metabisulfiet, $100 \mu \mathrm{g} / \mathrm{ml}$ bovine serum albumine, en $2 \%(\mathrm{w} / \mathrm{v}$ ) polyvinylpolypyrrolidone). Dit mengsel werd 30 seconden gehomogeniseerd met een ultraturrax-apparaat. Vervolgens werd 1,5 $\mathrm{ml}$ van het homogenaat gecentrifugeerd (Eppendorfcentrifuge, 8 minuten, 15,000 rpm); het heldere supernatant werd gebruikt als enzympreparaat.

Uitvoering van de enzym-assay: $25 \mu$ lenzympreparaat werd 120 minuten geincubeerd met $1 \%$ laminarine in $150 \mu \mathrm{l} 50 \mathrm{mM}$ natriumacetaat-buffer $\mathrm{pH} 5.5 \mathrm{bij} 40^{\circ} \mathrm{C}$. De reactie werd gestopt door toevoeging van $350 \mu$ l DNSA-reagens, waarna het mengsel onmiddellijk 5 minuten verhit werd bij 100 ${ }^{\circ} \mathrm{C}$. Na afkoeling tot kamertemperatuur werd de absorptie van de oplossing bepaald bij $540 \mathrm{~nm}$.

\subsection{Bepaling van PR1-expressie in tomaat}

RNA werd geïsoleerd met behulp van de RNeasy Plant Mini Kit (74904, Qiagen) volgens het protocol van de fabrikant. Het uitgangsmateriaal was $\pm 100 \mathrm{mg}$ in vloeibare stikstof vermalen tomatenblad. Het RNA werd geëlueerd in $50 \mu$ nuclease vrij water en bewaard bij $-20{ }^{\circ} \mathrm{C}$ tot verdere verwerking. Na RNA isolatie werd $1 \mu \mathrm{l}$ van het geïsoleerde RNA behandeld met DNase I,amplification grade (18068015, Invitrogen) volgens het bijgesloten protocol van de kit. Om te controleren of tijdens de DNase behandeling daadwerkelijk al het DNA was afgebroken, werd $1 \mu \mathrm{l}$ van het behandelde RNA op een $1 \%$ agarosegel gecontroleerd. Van het behandelde RNA werd $7 \mu$ gebruikt als template voor cDNA 
synthese. cDNA werd gesynthetiseerd met de iScript Reverse Transcription Supermix (1708841, BioRad). Het cDNA werd 5 maal verdund in nuclease vrij water voor gebruik in de qPCR reactie. De samenstelling van de qPCR reactiemix was als volgt: 1 x SYBR Premix Ex Taq (TaKaRa), $0.2 \mu \mathrm{M}$ forward primer, $0.2 \mu \mathrm{M}$ reverse primer (tabel 6.1), $2 \mu \mathrm{l}$ cDNA en aangevuld tot $20 \mu \mathrm{l}$ met nuclease vrij water. De qPCR reactie werd uitgevoerd in een Quantstudio 12K Flex Real-Time PCR apparaat (ThermoFisher) volgens het volgende reactieprogramma: 1) $\left.60 \mathrm{sec} 95^{\circ} \mathrm{C}, 2\right) 40 \mathrm{cycli}$ van $10 \mathrm{sec} 95$ ${ }^{\circ} \mathrm{C}$ en $40 \mathrm{sec} 60^{\circ} \mathrm{C}$ en 3 ) een default smeltcurve. Elk cDNA monster werd in tweevoud geanalyseerd met alle 3 de primersets.

Tabel 6.1 Overzicht van de primers die tijdens de analyse gebruikt zijn.

\begin{tabular}{|c|c|c|c|}
\hline primer naam & sequentie $\left(5^{\prime} \rightarrow 3^{\prime}\right)$ & gen & database $\mathrm{nr}$. \\
\hline $\begin{array}{l}\text { SIPR1a4_F } \\
\text { SIPR1a4_R }\end{array}$ & $\begin{array}{l}\text { GTGTCCGAGAGGCCAGACTA } \\
\text { CATTGTTGCAACGAGCCCGA }\end{array}$ & Pathogenesis related protein 1 & $\begin{array}{l}\text { PRJNA413174 } \\
\text { (chr 9) }\end{array}$ \\
\hline $\begin{array}{l}\text { Ef1a_F } \\
\text { Ef1a_R }\end{array}$ & $\begin{array}{l}\text { ACAGGCGTTCAGGTAAGGAA } \\
\text { GAGGGTATTCAGCAAAGGTCTC }\end{array}$ & Elongation factor 1-alpha & $\begin{array}{l}\text { PRJNA413174 } \\
(\mathrm{chr} 6)\end{array}$ \\
\hline $\begin{array}{l}\text { L33_F } \\
\text { L33_R }\end{array}$ & $\begin{array}{l}\text { GGGAAGAGGCTGGGATACATC } \\
\text { AGGAGGCAAATTGGACTTGAAC }\end{array}$ & 60S ribosomal protein L33-B & $\begin{array}{l}\text { PRJNA413174 } \\
\text { (chr 3) }\end{array}$ \\
\hline
\end{tabular}

Voor de PR1 bepalingen in het experiment van september 2018 werd van bovenstaand protocol afgeweken op de volgede punten: de qPCR reactiemix was $1 \times$ PerfeCTa SYBR Green Supermix (QuantaBio), en het reactieprogramma was: (1) $150 \mathrm{sec} 95^{\circ} \mathrm{C}$, (2) $40 \mathrm{cycli}$ van $10 \mathrm{sec} 95^{\circ} \mathrm{C}$ en 40 $\sec 60^{\circ} \mathrm{C}$ en (3) een default smeltcurve.

\subsection{Bepaling van salicylzuur en jasmonzuur}

Aan $300 \mathrm{mg}$ bevroren en fijngemalen bladmateriaal werd in een $2 \mathrm{ml}$ Eppendorfvaatje $1 \mathrm{ml} 90 \%$ methanol in MQ-water toegevoegd dat deuterium-gelabeld salicylzuur (200 ng) en jasmonzuur (200 $\mathrm{ng}$ ) bevatte als interne standaard. Het mengsel werd 15 minuten blootgesteld aan ultrasonicatie en vervolgens 15 minuten gecentrifugeerd. De pellet werd opnieuw geëxtraheerd met $1 \mathrm{ml} 100 \%$ methanol, waarna beide supernatanten samengevoegd werden en gedroogd. De geëxtraheerd verbindingen werden heropgelost in $1 \mathrm{ml} 75 \%$ methanol middels 15 minuten ultrasonicatie. Om het gehalte vrij (ongeconjugeerd) hormoon te bepalen, werden de extracten direct geanalyseerd met LCMS. Voor de analyse van totaal salicylzuur (vrij plus geconjugeerd) werd $500 \mu$ l van het methanolextract gemengd met $500 \mu \mathrm{l} 0.2 \mathrm{M}$ natriumacetaatbuffer $\mathrm{pH} 4.5$ dat $0.5 \mathrm{mg}$ almond $\beta$-glucosidase (Sigma, code 49290, 7.8 units per mg) bevatte. Na 14 uur incuberen bij $37^{\circ} \mathrm{C}$, werd het incubatiemengsel aangezuurd tot $\mathrm{pH} 1-1.5$ door $10 \mu \mathrm{l}$ geconcentreerd $\mathrm{HCl}$ toe te voegen en te mengen met $700 \mu \mathrm{l}$ cyclopentaan-ethylacetaat-isopropanol (50:50:1; v/v). Na centrifugatie werd de bovenste fase verzameld en de onderste fase opnieuw geextraheerd met cyclopentaan-ethylacetaatisopropanol. Beide bovenste fases werden samengevogd en gedroogd in een speedvac. De geextraheerde verbindingen werden opgelost in 75\% methanol door 15 min ultrasonicatie, waarna ze geanalyseerd werden met LCMS. Jasmonzuur werd slechts bepaald in haar vrije vorm, aangezien de de-conjugeringsbehandeling tot significante verliezen van dit hormoon bleek te leiden. LCMS werd uitgevoerd op een UltiMate 3000 U-HPLC (Dionex) gekoppeld aan een accurate massa Q

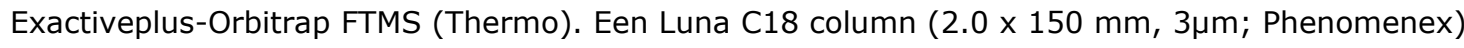
gethermostreerd op $40^{\circ} \mathrm{C}$ en een 25 minutes lineaire gradient van 5 tot $75 \%$ acetonitril in $0.1 \%$ mierenzuur in water met een elutiesnelheid van $0.19 \mathrm{ml} \mathrm{min-1}$ werden gebruikt om de deuteriumgelabelde and ongelabelde hormonen te scheiden. Injectievolume per extract was $5 \mu$ l. De FTMS was ingesteld op een resolutie van 70,000 in negatieve electrospray ionizatie modus om de specifieke massa van de eluerende verbindingen te detecteren. Verdunningsreeksen van authentieke, 
ongelabelde standaarden werden geanalyseerd om de hormoongehaltes in de monsters te berekenen, waarbij de opbrengst van de gedeutereerde interne standaarden verdisconteerd werd.

\subsection{Statistische analyse}

De statistische data-analyses (ANOVA) werden uitgevoerd met GenStat (19e editie). In dit rapport wordt het resultaat significant genoemd indien de P-waarde ( $F$ probability) kleiner dan 0.05 is. 


\section{Literatuur}

- Ballaré CL, Mazza CA, Austin AT, Pierik R (2012) Canopy light and plant health. Plant Physiology 160: 145-155.

- $\quad$ Cohen Y, Rotem J (1970) The relation of sporulation to photosynthesis in some obligatory and facultative parasites. Phytopathology 60: 1600-1604.

- Conrath U, Beckers GJM, Langenbach CJG, Jaskiewicz MR (2015) Priming for enhanced defence. Annu. Rev. Phytopathol. 53:97-119.

- de Wit M, Spoel SH, Sanchez-Perez GF, Gommers CMM, Pieterse CMJ, et al (2013) Perception of low red:far-red ratio compromises both salicylic acid- and jasmonic acid-dependent pathogen defences in Arabidopsis. Plant J. 75:90-103.

- Delaney, T.P., Uknes, S., Vernooij, B., Friedrich, L., Weymann, K., Negrotto, D., Gaffney, T., GutRella, M., Kessmann, H., Ward, E. and Ryals, J. (1994) A central role of salicylic acid in plant disease resistance. Science 266: 1247-1250.

- Genoud et al (2002). Phytochrome signalling modulates the SA-perceptive pathway in Arabidopsis. Plant J 31: 87-95.

- $\quad$ Genoud T, et al (2002) The Plant Journal 31: 87-95.

- Gozzo F en Faoro F (2013) Systemic Acquired Resistance (50 Years after Discovery): Moving from the Lab to the Field. J Agr Food Chem 61: 12473-12491.

- Griebel T, Zeier J (2008) Light regulation and daytime dependency of inducible plant defenses in Arabidopsis: phytochrome signaling controls systemic acquired resistance rather than local defense. Plant Physiology 147: 790-801.

- Huang X, Ouyang X, Deng XW (2014) Beyond repression of photomorphogenesis: role switching of COP/DET/FUS in light signaling. Current Opinion in Plant Biology 21: 96-103.

- Islam SZ, Babadoost M, Honda Y (2002) Effects of red light treatments on seedlings of pepper, pumpkin and tomato on the occurrence of Phytophthora damping-off. HortScience 37: 678-681.

- Islam SZ, Honda Y, Arase S (1998). Light-induced resistance of broad bean against Botrytis cinerea. Journal of Phytopathology 146: 479-485.

- Jenkins GI, Long JC, Wade HK, Shenton MR, Bibikova TN (2001) UV and blue light signalling: pathways regulating chalcone synthase gene expression in Arabidopsis. New Phytologist 151: 121131.

- $\quad$ Kurepin LV et al, 2010. Light regulation of endogenous salicylic acid levels in hypocotyls of Helianthus anuus seedlings. Botany 88: 668-674.

- $\quad$ Lawton K, Friedrich L, Hunt M, Weymann K, Delaney T, Kessmann H, Staub T, Ryals J (1996) Benzothiadiazole induces disease resistance in Arabidopsis by activation of the systemic acquired resistance signal transduction pathway, Plant J., 10: 71-82.

- Luna E, Van Hulten M, Zhang Y, Berkowitz O, López A, Pétriacq P, et al. (2014) Plant perception of $\beta$-aminobutyric acid is mediated by an aspartyl-tRNA synthetase. Nat. Chem. Biol. 10, 450-456.

- Mayer R, Raventos D, Chua NH (1996) det1, cop1, and cop9 mutations cause inappropriate expression of several gene sets. Plant Cell 8: 1951-1959.

- $\quad$ Miller GL (1959), Use of dinitrosalicylic acid reagent for determination of reducing sugar. Anal. Chem. 31: 426-428.

- Pennypacker BW (2000) Differential impact of carbon assimilation on the expression of quantitative and qualitative resistance in alfalfa (Medicago sativa). Physiological and Molecular Plant Pathology 57: 87-93.

- Roberts MR, Paul ND (2006) Integrating molecular and ecological perspectives on the influence of light on plant defence against pests and pathogens. New Phytologist 170: 677-699.

- Robert-Seilaniantz A, Grant M, Jones JDG (2011) Hormone crosstalk in plant disease and defense: more than just jasmonate-salicylate antagonism. Annu. Rev. Phytopathol. 49:317-343.

- Roden LC, Ingle RA (2009) Lights, rhythms, infection: the role of light and the circadian clock in determining the outcome of plant-pathogen interactions. The Plant Cell 21: 2546-2552.

- Schuerger AC, Brown CS (1997). Spectral quality affects disease development of three pathogens on hydroponically grown plants. Hortscience 32: 96-100.

- Shafia A, Sutton JC, Yu H, Fletcher RA (2001) Influence of preinoculation light intensity on development and interactions of Botrytis cinerea and Clonostachys rosea in tomato leaves. Canadian Journal of Plant Pathology 23: 261-268. 
- Suthaparan A, Stensvand A, Torre S, Herrero ML, Pettersen RI, Gadoury DM, Gislerød HR (2010a) Continuous lighting reduces conidial production and germinability in the rose powdery mildew pathosystem Plant Disease 94: 339-344.

- $\quad$ Suthaparan A, Torre, S, Stensvand, A, Herrero ML, Pettersen RI, Gadoury DM, Gislerød HR (2010b) Specific light-emitting diodes can suppress sporulation of podosphaera pannosa on greenhouse roses. Plant Disease 94: 1105-1110.

- Ton J, Jakab G, Toquin V, Flors V, Iavicoli A, Maeder MN, et al. (2005). Dissecting the betaaminobutyric acid-induced priming phenomenon in Arabidopsis, Plant Cell 17, 987-999.

- Tripathi D, Jiang Y-L, Kumar D (2010) SABP2, a methyl salicylate esterase is required for the systemic acquired resistance induced by acibenzolar-S-methyl in plants, FEBS Lett. 584, 34583463

- Vernooij B, Friedrich L, Ahl-Goy P, Staub Y, Kessmann H, Ryals J (1995) 2,6-Dichloroisonicotinic acid-induced resistance to pathogens without the accumulation of salicylic acid, Mol. Plant Microbe Interact., 8 (1995), pp. 228-234.

- Walters DR, Ratsep J, Havis ND (2013). Controlling crop diseases using induced resistance: challenges for the future. J. Exp. Bot. 64 (5): 1263-1280.

- Wang H, Jiang YP, Yu HJ, Xia XJ, Shi K, Zhou YH (2010) Light quality affects incidence of powdery mildew, expression of defence-related genes and associated metabolism in cucumber plants. Eur. J. Plant Pathol. 127: 125-135.

- Wang H, Yu JQ, Jiang YP, Yu HJ, Xia XJ, K, Zhou YH (2010). Light quality affects incidence of powdery mildew, expression of defence-related genes and associated metabolism in cucumber plants. Eur. J. Plant Pathol.127:125-135.

- Wei N, Deng X-W (1996) The role of the COP/DET/FUS genes in light control pf Arabidopsis seedling development. Plant Physiol 112: 871-878.

- Wu L, Yang H-Q (2010) CRYPTOCHROME 1 is implicated in promoting R protein-mediated plant resistance to Pseudomonas syringae in Arabidopsis. Mol. Plant 3:539-48.

- Yoshioka K, Nakashita H, Klessig DF, Yamaguchi I (2001) Probenazole induces systemic acquired resistance in Arabidopsis with a novel type of action, Plant J 25:149-157.

- Zeier J et al (2004). Light conditions influence specific defence responses in incompatible plantpathogen interactions: uncoupling systemic resistance from salicylic acid and PR-1 accumulation. 
Correspondentie adres voor dit rapport: Postbus 16

6700 AA Wageningen

T 0317480700

www.wur.nl/plant-research
De missie van Wageningen University \& Research is 'To explore the potential of nature to improve the quality of life'. Binnen Wageningen University \& Research bundelen Wageningen University en gespecialiseerde onderzoeksinstituten van Stichting Wageningen Research hun krachten om bij te dragen aan de oplossing van belangrijke vragen in het domein van gezonde voeding en leefomgeving. Met ongeveer 30 vestigingen, 5.000 medewerkers en 12.000 studenten behoort Wageningen University \& Research wereldwijd tot de aansprekende kennisinstellingen binnen haar domein. De integrale benadering van de vraagstukken en de samenwerking tussen verschillende disciplines vormen het hart van de unieke Wageningen aanpak. 